\title{
The Effect of Superiors' Mentoring on Subordinates' Organizational Identification and Workplace Outcomes
}

\author{
Molly S. Eickholt
}

Follow this and additional works at: https://researchrepository.wvu.edu/etd

\section{Recommended Citation}

Eickholt, Molly S., "The Effect of Superiors' Mentoring on Subordinates' Organizational Identification and Workplace Outcomes" (2018). Graduate Theses, Dissertations, and Problem Reports. 5533.

https://researchrepository.wvu.edu/etd/5533

This Dissertation is protected by copyright and/or related rights. It has been brought to you by the The Research Repository @ WVU with permission from the rights-holder(s). You are free to use this Dissertation in any way that is permitted by the copyright and related rights legislation that applies to your use. For other uses you must obtain permission from the rights-holder(s) directly, unless additional rights are indicated by a Creative Commons license in the record and/ or on the work itself. This Dissertation has been accepted for inclusion in WVU Graduate Theses, Dissertations, and Problem Reports collection by an authorized administrator of The Research Repository @ WVU.

For more information, please contact researchrepository@mail.wvu.edu. 
The Effect of Superiors' Mentoring on Subordinates'

Organizational Identification and Workplace Outcomes

Molly S. Eickholt

\author{
Dissertation submitted \\ to the Eberly College of Arts and Sciences \\ at West Virginia University \\ in partial fulfillment of the requirements for the degree of \\ Doctor of Philosophy in \\ Communication Studies
}

\author{
Scott A. Myers, Ph.D., Chair \\ Megan R. Dillow, Ph.D. \\ Alan K. Goodboy, Ph.D. \\ Matthew M. Martin, Ph.D. \\ Emily C. Tanner, Ph.D. \\ Department of Communication Studies
}

\author{
Morgantown, West Virginia \\ 2018
}

Keywords: mentor-protégé relationships, superior-subordinate relationships, organizational identification, mentoring functions, job satisfaction, communication satisfaction with superiors, organizational commitment Copyright 2018 Molly S. Eickholt 


\begin{abstract}
The Effect of Superiors' Mentoring on Subordinates'

Organizational Identification and Workplace Outcomes
\end{abstract}

Molly S. Eickholt

This dissertation investigated the relationships between subordinates' perceptions of the mentoring they receive from their superiors and their reports of organizational identification and workplace experiences. Specifically, the relationships between (1) career development and psychosocial mentoring functions and organizational identification, (2) organizational identification and job satisfaction, communication satisfaction, and organizational commitment, (3) and career development and psychosocial mentoring functions and job satisfaction, communication satisfaction and organizational commitment were examined. Furthermore, the indirect effect of mentoring functions on job satisfaction, communication satisfaction, and organizational commitment through organizational identification was examined. Paid, fully-employed adults completed an online survey measuring their perceptions of mentoring from their direct superior, organizational identification, job satisfaction, communication satisfaction with their superior, and organizational commitment. Results showed significant positive relationships between (1) the career development and psychosocial mentoring functions and organizational identification, (2) organizational identification and job satisfaction, communication satisfaction, and organizational commitment, and (3) mentoring functions and job satisfaction, communication satisfaction, and organizational commitment. Results also indicated evidence of an indirect effect of mentoring functions on subordinates' job satisfaction, communication satisfaction, and organizational commitment through subordinates' increased organizational identification. These results suggest that organizational identification is an important factor in enhancing employees' workplace experiences and that organizational leaders may consider fostering workplace environments in which employees are likely to identify with the organization. 


\section{ACKNOWLEDGEMENTS}

The completion of this dissertation would not have been possible without the help and support of many people important to me. Thank you to my advisor, Dr. Scott Myers, for always pushing me to improve the quality of my work, even when I believed I had reached my limit. In addition to what you have done to improve the quality of my work, you have also made me develop as a person. Thank you for teaching me the importance of intentionality, diligence, and empathy, concepts that I will undoubtedly incorporate in all aspects of my life, including my future career. I will always respect and appreciate you as a teacher, advisor, and person.

To my committee members, Dr. Megan Dillow, Dr. Alan Goodboy, Dr. Matthew Martin, and Dr. Emily Tanner, thank you for your invaluable perspective on this dissertation and for pushing me to improve upon my work. Dr. Dillow, thank you for always challenging me to work harder and to constantly strive to be better. Dr. Goodboy, I will always appreciate your friendship, loyalty, and constant assurances. No problem was to big (or small) for you to help me tackle. Thank you for understanding and appreciating my sense of humor more than most and for becoming a valuable friend. Dr. Martin, thank you for showing me what it means to be a member of our department's family. Dr. Tanner, thank you for your insight regarding this dissertation and for helping the completion of this dissertation come to fruition.

I am immensely thankful for my cohort members, Dana Borzea and Mary Donato. Dana and Mary, you gave me much needed humor, support, and encouragement throughout every step of this process. Knowing that I could turn to either one of you when I needed anything provided invaluable comfort and motivation to keep moving 
forward. I'm lucky to have become so close to my cohort members, and I do not take our unique bond for granted. I can't imagine my years in Morgantown without you both. To Jordan Atkinson, you have always been willing to provide counsel and guidance, and you have become one of my closest and dearest friends. I'm thankful that I was always able to chat about any problem or anxiety with you. To all three of you, Morgantown will always be a place where I laughed the hardest, especially when I needed it the most. The friendships we have created through this program will be friendships I take with me long after my time at WVU.

To others in the department, especially Joy Green, Terri Kelley, and Renee Kisner, thank you for your support and encouragement, as well as the tangible support your provided while I worked toward completing this degree. To all my other fellow WVU students, being a part of our department has placed us all together, and I'm so thankful I got landed with such a great group of people. Working with all of you especially Hannah Ball, Christine Anzur, Julie Weiss, James Baker, Cathlin ClarkGorden, and Sara Pitts - has made my experience here one of the funniest, weirdest, and most memorable stages of my life so far. To those of you who are still working to complete your degree: keep working and keep laughing.

The support I received from family and friends from afar is just as important as the support I received within the walls of Armstrong Hall. Notably, I would like to thank my parents for raising me with the strong conviction that I could achieve a lot if I work hard enough for it. I hope that I one day have the amount of work ethic that you have shown me. Perhaps more importantly, without you both as examples to whom I look up, I would not have my love of learning and insatiable curiosity about the world. My sisters, 
Jesse and Ashley, helped me maintain perspective throughout my years at WVU. As the youngest of three, I have always wanted to be like my sisters, and I'm thankful to have two sisters who serve as strong role models for me.

Thank you to Jacob Lilly, for being unwaveringly understanding and supportive of me. Knowing that I could turn to you whenever I needed made me feel like I could tackle any problem and that no mountain of work was too big. Your continual love and comfort has been invaluable to me and to my ability to successfully complete this program. Regardless of the geographic distance between us throughout most of our graduate careers, you have never doubted the strength of our relationship, which has been a vital constant for me.

Kevin Dmytryka and Betsy Bair kept me grounded and continually reminded me of my strong support system outside of Morgantown. It feels as though we were able to experience graduate school together as we pursued our degrees at our respective schools. I will forever be grateful for you both for always knowing exactly what I needed to hear, relentlessly assuring me that I had the ability to finish this program, and continually making me laugh and smile. I am immeasurably thankful for our inimitable friendship. Jenny Walton has shown unceasing support and confidence in me, especially when I lack confidence the most. Thank you for always helping me handle the stress of graduate school and for consistently telling me to stay positive and to keep moving forward. Brandi Frisby has shown me through example the importance of determination and a good heart. I look up to you and thank you both for guiding my path to WVU.

I've been lucky to have fulfilling friendships with exceptional people. To Cassie Rea, Amanda Winkle, Nicole Staricek, Katie Samijlenko, and Tina Rose, thank you for 
always supporting and believing in me. Your friendships have meant so much to me throughout graduate school and as I worked toward completing this dissertation and, I'm sure, will continue to well after graduation. 


\section{TABLE OF CONTENTS}

ABSTRACT. ii

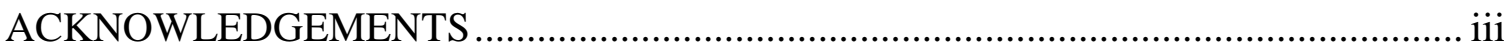

TABLE OF CONTENTS ..................................................................................... vii

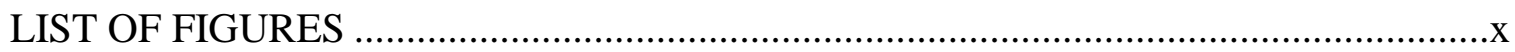

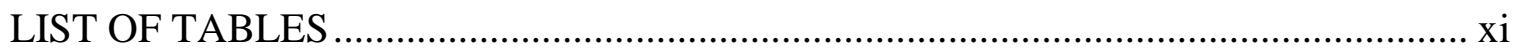

CHAPTER I: LITERATURE REVIEW .............................................................

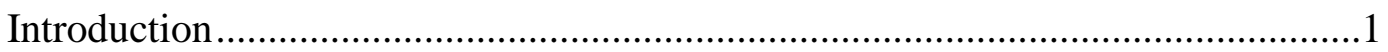

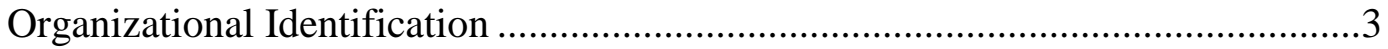

Organizational Psychology and Identification......................................4

Organizational Communication and Identification.................................5

Outcomes of Organizational Identification.........................................10

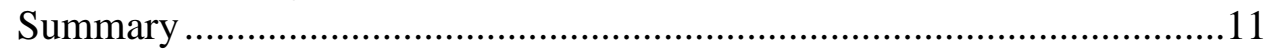

Mentor-Protégé Relationships ................................................................. 11

Career Development Functions..............................................................14

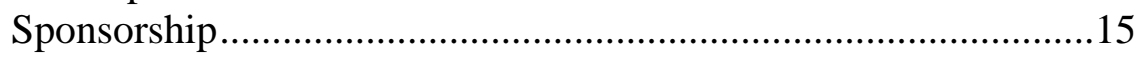

Exposure and Visibility.....................................................15



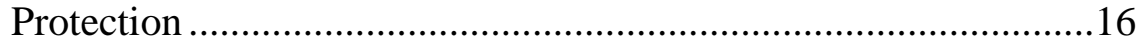

Challenging Assignments .................................................... 17

Psychosocial Functions ...................................................................... 18

Role Modeling .................................................................18

Acceptance and Confirmation.................................................19

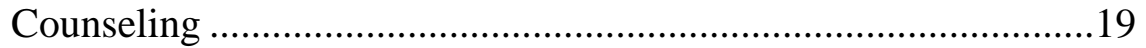



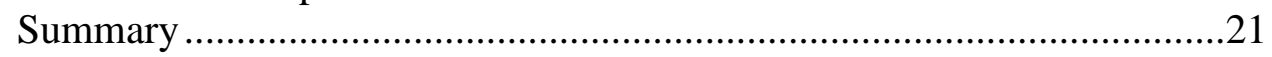





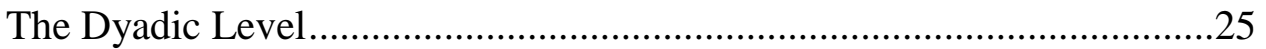

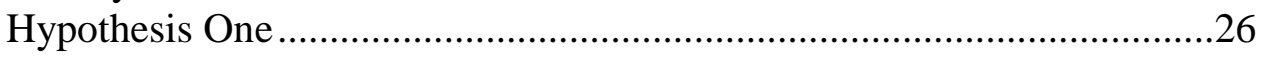



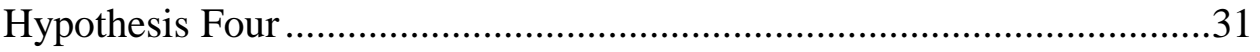

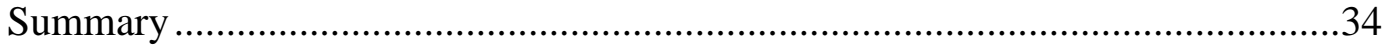

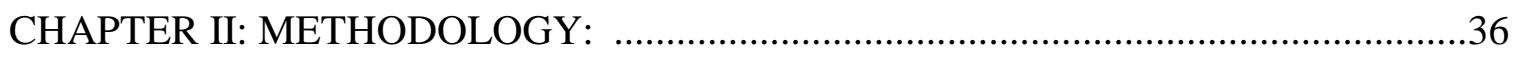

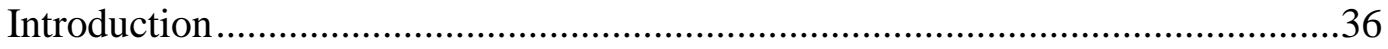

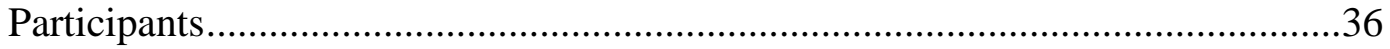

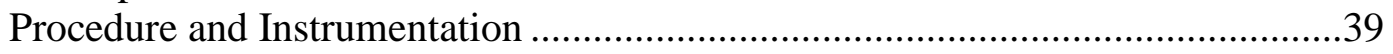


The Shortened Organizational Identification Questionnaire ....................41

The Mentor Role Instrument..................................................................4

The Abridged Job in General Scale ..........................................................42

The Interpersonal Communication Satisfaction Inventory ......................44

The Organizational Commitment Questionnaire .....................................43

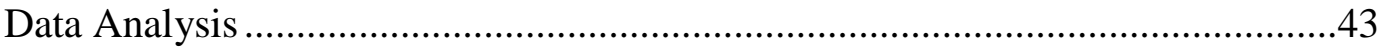



Primary Analyses ......................................................................... 44

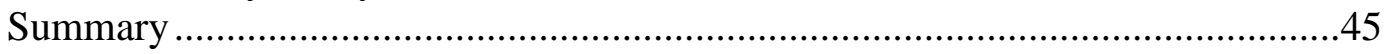

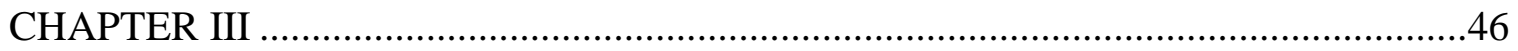

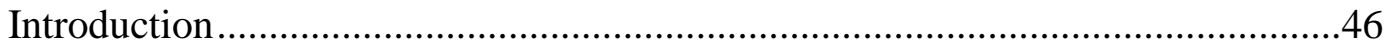

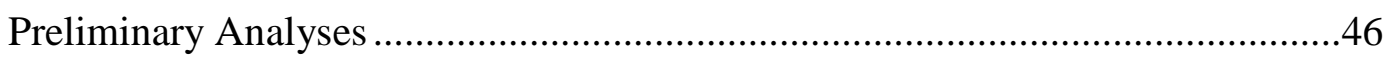

Cronbach's Alpha Reliability Coefficient Analysis ................................46

Two-Tailed Correlation Analysis .......................................................46

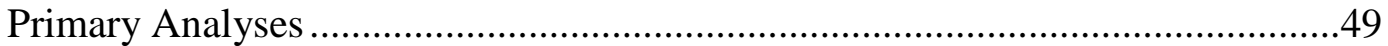

Preliminary Analyses for Hypotheses One, Two, and Three....................49

Length of Time Working for Their Organization ........................49

Length of Time Working in Their Current Position ......................49

Length of Time Working with Their Current Supervisor ..............52

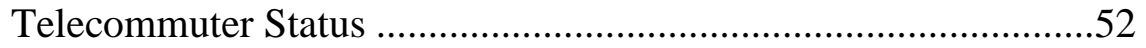

Country in which Their Organization is Located .........................55

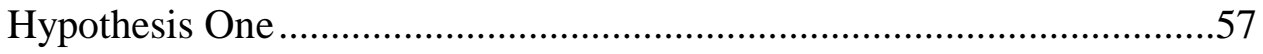

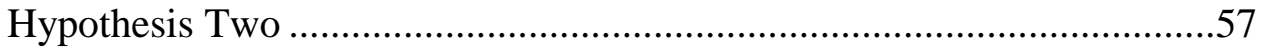

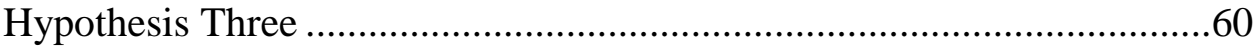

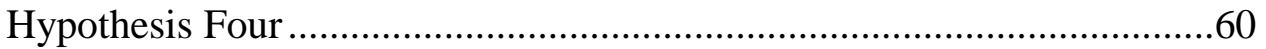

Job Satisfaction .............................................................62

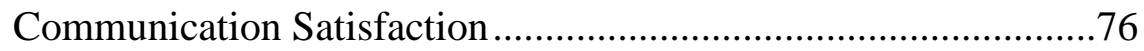

Organizational Commitment..................................................90

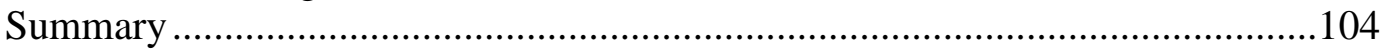

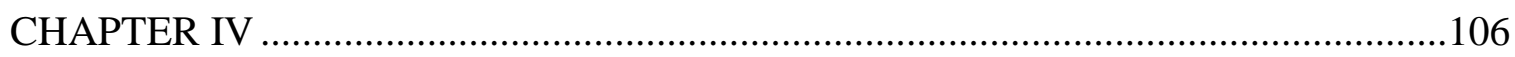

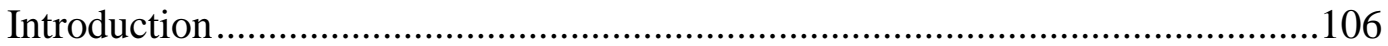

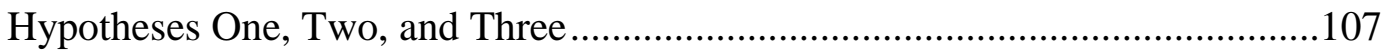

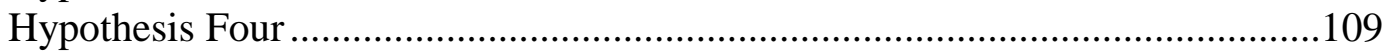

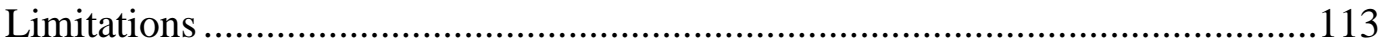

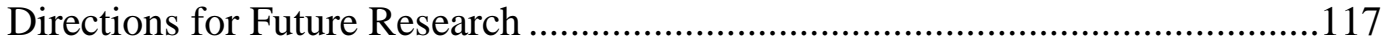

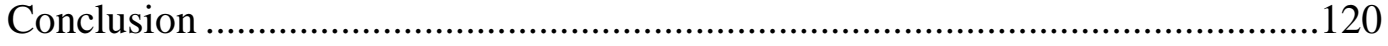

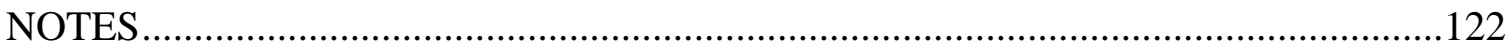

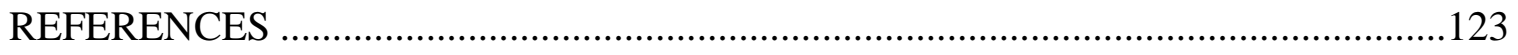

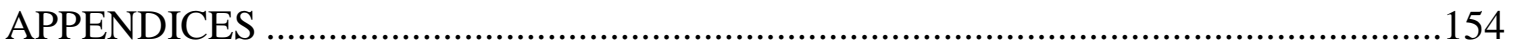




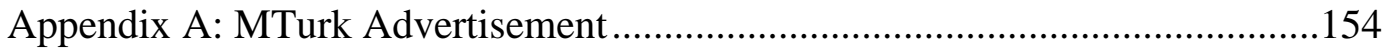

Appendix B: Cover Letter..........................................................................155

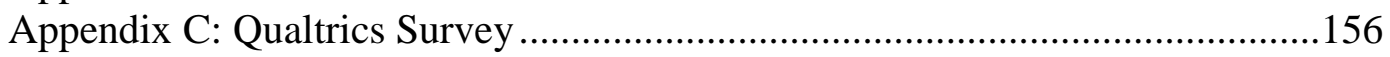

Appendix D: Shortened Organizational Identification Questionnaire .................174

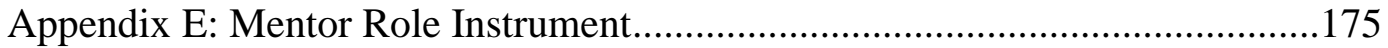

Appendix F: Abridged Job in General Scale ...............................................177

Appendix G: Interpersonal Communication Satisfaction Inventory ..................178

Appendix H: Organizational Commitment Questionnaire ................................179 


\section{LIST OF FIGURES}

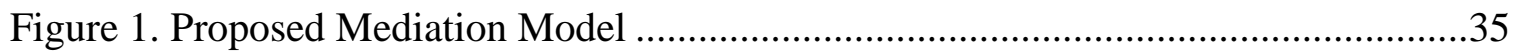




\section{LIST OF TABLES}

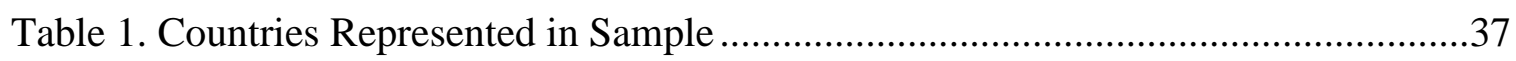

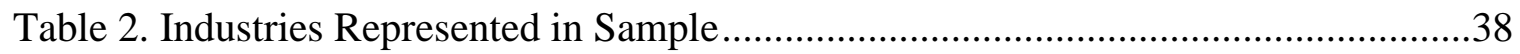

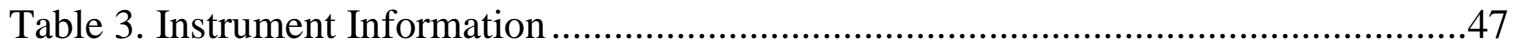

Table 4. Correlation Matrix .................................................................................4

Table 5. Length of Time Working for Their Organization ..............................................50

Table 6. Length of Time Working in Their Current Position ........................................51

Table 7. Length of Time Working with Their Current Supervisor .................................53

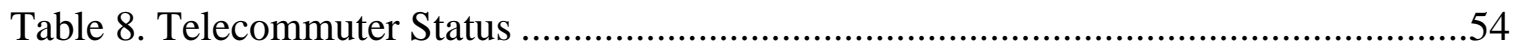

Table 9. Country in which Their Organization is Located ..........................................56

Table 10. Hypothesis One Partial Correlation Matrix .................................................58

Table 11. Hypothesis Two Partial Correlation Matrix...................................................59

Table 12. Hypothesis Three Partial Correlation Matrix..............................................61

Table 13. Unstandardized Path Coefficients for Sponsorship and Job Satisfaction Model

Table 14. Unstandardized Path Coefficients for Exposure and Visibility and Job

Satisfaction Model

Table 15. Unstandardized Path Coefficients for Coaching and Job Satisfaction Model ...66

Table 16. Unstandardized Path Coefficients for Protection and Job Satisfaction Model..67

Table 17. Unstandardized Path Coefficients for Challenging Assignments and Job Satisfaction Model

Table 18. Unstandardized Path Coefficients for Role Modeling and Job Satisfaction Model

Table 19. Unstandardized Path Coefficients for Acceptance and Confirmation and Job Satisfaction Model

Table 20. Unstandardized Path Coefficients for Counseling and Job Satisfaction Model 73 
Table 21. Unstandardized Path Coefficients for Friendship and Job Satisfaction Model .75

Table 22. Unstandardized Path Coefficients for Sponsorship and Communication Satisfaction Model

Table 23. Unstandardized Path Coefficients for Exposure and Visibility and Communication Satisfaction Model .78

Table 24. Unstandardized Path Coefficients for Coaching and Communication Satisfaction Model .80

Table 25. Unstandardized Path Coefficients for Protection and Communication Satisfaction Model

Table 26. Unstandardized Path Coefficients for Challenging Assignments and Communication Satisfaction Model .83

Table 27. Unstandardized Path Coefficients for Role Modeling and Communication Satisfaction Model

Table 28. Unstandardized Path Coefficients for Acceptance and Confirmation and Communication Satisfaction Model

Table 29. Unstandardized Path Coefficients for Counseling and Communication Satisfaction Model .88

Table 30. Unstandardized Path Coefficients for Friendship and Communication Satisfaction Model

Table 31. Unstandardized Path Coefficients for Sponsorship and Organizational Commitment Model

Table 32. Unstandardized Path Coefficients for Exposure and Visibility and Organizational Commitment Model

Table 33. Unstandardized Path Coefficients for Coaching and Organizational Commitment Model

Table 34. Unstandardized Path Coefficients for Protection and Organizational Commitment Model .96

Table 35. Unstandardized Path Coefficients for Challenging Assignments and Organizational Commitment Model

Table 36. Unstandardized Path Coefficients for Role Modeling and Organizational Commitment Model 
Table 37. Unstandardized Path Coefficients for Acceptance and Confirmation and Organizational Commitment Model

Table 38. Unstandardized Path Coefficients for Counseling and Organizational Commitment Model.

Table 39. Unstandardized Path Coefficients for Friendship and Organizational Commitment Model 


\section{CHAPTER I}

\section{Literature Review}

Within the workplace, individuals may feel a strong sense of connection and identification with the goals and needs of their organization. Organizational members who connect and identify with their organization typically are more committed to the organization, which increases employee retention rates and promotes employee decisionmaking that benefits the organization (Cheney, 1983a; Bullis \& Tompkins, 1989; Mael \& Tetrick, 1992; Scott \& Stephens, 2009). Furthermore, as organizational members who identify with their organization feel connected with, and committed to, the organization, they also promote a positive external image of the organization to others (Cheney \& Christensen, 2001). For these reasons, organizational identification generally is beneficial for the success of the organization, and many organizations strive to promote organizational identification among its employees. Although many factors within an organization influence organizational members' degree of organizational identification, the relationships and social ties individuals make directly impact the extent to which organizational members identify with their organization (Cheney, Christensen, \& Dailey, 2014; Jones \& Volpe, 2010).

One specific type of relationship that can impact organizational members' organizational identification is the superior-subordinate relationship. In a review of the research conducted on the superior-subordinate relationship to date, Sias (2009) summarized the functions of the superior-subordinate relationship for both superiors and subordinates: to exchange information, to provide feedback and appraisal, to exert power and influence, and to engage in mentoring and leadership. Mentor-protégé relationships 
help socialize individuals to their organization as well as enhance the development of protégés' careers and provide psychosocial support to those individuals within the relationship (Baugh \& Fagenson-Eland, 2007; Kram, 1983), which also positively affects protégés' organizational identification (Bullis \& Bach, 1989a). Although protégés receive these benefits from mentors within the organization, organizational members also can be mentored by other individuals, including mentors outside of the organization, peer coworkers, and superiors (Kram, 1983, 1988). This dissertation examines specifically the mentoring individuals receive from their superiors and the extent to which superior mentoring increases subordinate organizational identification.

Investigating mentoring within the superior-subordinate relationship and subordinate organizational identification is important for extending existing organizational communication research and for practical use within the workplace. Extant research overwhelmingly demonstrates the importance of organizational identification to organizational productivity and the well-being of protégés and mentors (e.g., Kram, 1983), as well as organizational members upholding the values and goals of the organization and promoting these values and goals to others outside of the organization (Cheney \& Christensen, 2001). However, much of this research examines mentoring without considering the superior as a possible mentor. This dissertation extends extant mentoring research by suggesting that superiors who serve mentoring functions to their subordinates directly (a) influence subordinates' organizational identification and (b) improve subordinates' overall affect toward their superior, job, and organization as a result of their increased identification.

This chapter is divided into three sections. The first section traces the 
development of the organizational identification construct and discusses the outcomes associated with organizational identification. The second section conceptualizes mentorprotégé relationships, explains the functions these relationships serve, and identifies the outcomes associated with these relationships. The third section provides a rationale for this dissertation, including the four hypotheses posited for this study.

\section{Organizational Identification}

Understanding organizational identification is important for the vitality of an organization as promoting a strong positive external identity is difficult among organizations without strongly identified individuals within them (Cheney \& Christensen, 2001). For individuals within the organization, organizational identification can fulfill the innate desire to create and maintain interpersonal connections with others (Baumeister \& Leary, 1995) and membership in, or belonging to, a collective (Mael \& Ashforth, 1992; Patchen, 1970). For most individuals, much of their working lives is spent within an organization. As such, they often rely on their employment, or their status or role within their workplace, as a form of identity (Levinson, 1965), which can result in their using attributes of the organization's identity to define themselves as organizational members (Cheney et al., 2014).

Because the organizational identification construct has been examined by organizational researchers across several disciplines, a clear delineation of the conceptualization of identification is needed. The following subsections review the conceptualization of the organizational identification construct from an organizational psychological perspective, the conceptualization of the organizational identification construct from a communication studies perspective, and the outcomes associated 
generally with organizational identification.

\section{Organizational Psychology and Identification}

The process by which individuals establish their identity as members of an organization has been the focus of organizational research across several academic disciplines. The diversity of researchers who has investigated organizational identification has led to several different conceptualizations of this construct. Although the construct has been examined among organizational behavior researchers (Kaufman, 1960/2006; van Knippenberg \& Sleebos, 2006; van Knippenberg \& van Schie, 2000) and marketing researchers (Bhattacharya \& Elsbach, 2002; Bhattacharya, Rao, \& Glynn, 1995; Bhattacharya \& Sen, 2003), seminal conceptualizations of the organizational identification construct began from an organizational psychology perspective (Hall, Schneider, \& Nygren, 1970; O’Reilly \& Chatman, 1986; Patchen, 1970) to investigate how organizations influence their members' identity within and outside of the organization.

Organizational identification was conceptualized first as an individual's perception of oneness, loyalty, and similarity with an organization. Patchen (1970) posited that identification consists of three experiences: solidarity, support, and shared characteristics. Solidarity refers to feelings of belongingness or oneness with the organization and generally occurs when an individual's goals overlap with the organization's goals. Support toward the organization (i.e., loyalty) is embodied by an individual's supportive attitudes or behaviors toward the organization. Shared characteristics is defined as the similarities individuals perceive having in common with other organizational members. Before individuals can experience feelings of solidarity 
and support, they must first experience shared characteristics (Patchen).

Two other sets of organizational psychology researchers have conceptualized organizational identification in terms of fulfilling individual and organizational needs and goals. Hall et al. (1970) conceptualized organizational identification as the convergence between individual and organizational goals. From their perspective, organizational identification occurs when employees perceive the organization's needs as their own. In this sense, highly identified individuals place the needs of the organization above their own needs, which is characterized by a decrease in the perceived importance of individual need fulfillment and an increase in the perceived importance of organizational goals. They further posited that individuals who enter an organization already receptive to the organization's attempts to promote organizational identification (i.e., individuals with values similar to the organization) are more likely to identify with the organization. Ashforth and Mael (1989) later conceptualized organizational identification as the sense of belonging to an organization that individuals perceive; it is through this sense of belonging that individuals define their sense of self based on their membership within the organization. Rooted in social identity theory (Tajfel \& Turner, 1986), Ashforth and Mael argued that organizational identification is a specific type of social identity, which combines with other identities (e.g., gender, religious affiliation) to create an overall selfconcept.

\section{Organizational Communication and Identification}

Cheney (1983a, 1983b) was the first scholar to investigate organizational identification from a communication studies perspective by conceptualizing organizational identification as the active process in which individuals define themselves 
based on their belongingness to an organization. Specifically, he (Cheney, 1983a, 1983b;

Cheney \& Tompkins, 1987) posited that organizational identification centers on individuals' decision-making processes, such that organizational identification leads employees to consider alternatives in light of organizational interests and values when making job-related decisions. That is, those employees who highly identify with their organization consider the needs and interests of their department and organization as their own (Cheney, 1983a) and make job-related decisions based on what is best for the organization (Bullis \& Tompkins, 1989). Furthermore, as individuals identify more with their organization, they perceive an overlap between themselves and their organization and view decision-making and specific issues from such a perspective to benefit the organization (Cheney, 1983b).

For organizational identification to occur, employee perceptions of, and integration into, the organization's culture is an important predictor of organizational identification. When newcomers first join an organization, they learn the values and norms of organizational members (i.e., socialization; Van Maanen, 1978) and begin the process of becoming integrated within and adjusting to the organization's culture (i.e., assimilation; Jablin, 2001; Kramer \& Miller, 1999). Through the socialization process, the organization makes efforts to instill the values and norms of the organization among newcomers. As newcomers become socialized, they begin assimilating to the organization by accepting or influencing the organization's culture, and, as a result, tend to become more highly identified with the organization (Bullis \& Bach, 1989b; Myers \& Oetzel, 2001). The process of organizational identification, however, can start as early as pre-organizational entry, based on individuals' perceptions of the organization before 
becoming organizational members (Ashforth \& Mael, 1989; Bullis \& Bach; Stephens \& Dailey, 2012).

Once officially organizational members, the orientation programs and the efforts organizations make to integrate individuals into their organizational roles can increase organizational identification (Bullis, 1993; Stephens \& Dailey, 2012). Additionally, individuals' perceptions of the organization's culture are linked directly with their degrees of organizational identification. Specifically, employee morale, teamwork and coordination between organizational members, responsiveness to employee input and facilitation of employee interaction, effective communication flow and freedom of speech, clarity and appropriateness of feedback and expectations from superiors, and productivity of meetings is associated positively with employee organizational identification (Croucher, Long, Meredith, Oommen, \& Steele, 2009; Kassing, 2000a; Reed, Goolsby, \& Johnston, 2016; Schrodt, 2002). Additionally, when employees recognize an opportunity for professional achievement in the organization, perceive the organization as having high prestige, have individual goals that align with management goals, possess positive attitudes toward organizational reward and promotion systems, and partake in decision-making, they are more likely to be more highly identified with their organization (Lee, 1971). Communication practices that promote team synergy (e.g., maintaining a positive workplace climate) or group membership also increases both team and organizational identification (Silva \& Sias, 2010), which then reduces employees' intent to leave the workplace (Apker, Propp, \& Ford, 2009).

Generally, organizations make efforts to increase identification among their employees, and those employees who are inclined to identify with the organization are 
more receptive to these efforts (Cheney, 1983b). Cheney identified several strategies organizations employ to promote employee identification, including establishing common ground with employees, uniting against a common enemy, using inclusive language, and displaying symbols (e.g., logos, slogans) that encourage identification among their employees. Despite an organization's use of these strategies, however, individuals may experience fluctuating degrees of organizational identification over time (Ashforth \& Mael, 1989; Bullis \& Bach, 1989a; Stephens \& Dailey, 2012).

Scott, Corman, and Cheney (1998) later proposed a structurational model of identification, which reconceptualized identification in terms of social identity theory (Tajfel \& Turner, 1986) and structuration theory (Giddens, 1979). Within their model, identity (i.e., the central characteristics and rules that represent the organization) and identification are presented as a duality in which identity provides a structure of rules employees follow that constrain their behavior to agreed-upon norms of the organization. Identification, then, becomes the process by which this identity is maintained through social interaction within and outside of the organization. Furthermore, individuals' identification when communicating with other organizational members differs from the degree of identification experienced when communicating with friends or family (Scott \& Stephens, 2009).

Within the structurational model of organizational identification (Scott et al., 1998), employees have four separate identities that they maintain: an individual identity (i.e., their own personal interests and needs), a group identity (i.e., the interests and needs of a work team or department within the organization), an organizational identity (i.e., the interests and needs of the employing organization), and an occupational or professional 
identity (i.e., the interests and needs of the industry in which the individual is employed). Not only can these four identities conflict or overlap with each other, but also it is possible that individuals may not maintain all four identities (e.g., identify with a work group and not identify with the department), or they may have a combination of multiple unique and distinct identities within an organization (e.g., work group, department, union; Ashforth \& Mael, 1989; Barker \& Tompkins, 1994; van Dick, Wagner, Stellmacher, \& Christ, 2004).

Since Cheney's (1983a, 1983b) original work, organizational identification research conducted among organizational communication scholars has evolved to examine organizational identification among different types of workers and within various organizational contexts. Specifically, organizational communication scholars have explored organizational identification among virtual workers (Fay \& Kline, 2012; Fonner \& Roloff, 2012; Wiesenfeld, Raghuram, \& Garud, 2001), volunteers (Kang, 2016; Kramer, Meisenbach, \& Hansen, 2013; Meisenbach \& Kramer, 2014; Tornes \& Kramer, 2015) and temporary employees (Agarwal \& Buzzanell, 2015; Gossett, 2002). They also have investigated organizational identification among members of specific types of organizations, such as hidden organizations (i.e., organizations where members' identity is largely concealed; Askay \& Gossett, 2015), agricultural businesses (Morgan et al., 2004), faith-based organizations (Driskill \& Camp, 2006; McNamee, 2011), and social service organizations (Maneerat, Hale, \& Singhal, 2005). Although the majority of organizational identification research examines organizational identification organizational members experience in general, other researchers have examined organizational identification specifically during times of organizational change, such as 
throughout rebranding efforts (Gilstrap \& Smith, 2016) or situations in which an organization is perceived negatively by the public (Frandsen, 2012; Williams \& Connaughton, 2012).

\section{Outcomes of Organizational Identification}

From a communication studies perspective, organizational identification among employees typically is believed to be beneficial. Highly identified individuals generally are more satisfied with their jobs and their organization (Cho, Ramgolam, Schaefer, \& Sandlin, 2011; Myers, Davis, Schreuder, \& Seibold, 2016; Myers \& Oetzel, 2003; Scott \& Stephens, 2009). These employees also report that they have assimilated into the organization and generally intend to remain within their current organization (Myers \& Oetzel; Scott \& Stephens). They typically perform better within their job roles, are more trusting of their organization, engage more with their work, and, in some cases, experience lower levels of burnout (Kang, 2016; Korschun, Bhattacharya, \& Swain, 2014; Lammers, Atouba, \& Carlson, 2013; Myers et al.; Rapp, Ahnihotri, Baker, \& Andzulis, 2015).

Although highly identified employees generally experience positive workplace outcomes, organizational identification among employees also benefits the organization. For example, when organizations are accused of unethical practices, highly identified employees are likely to defend their organizations (Ploeger \& Bisel, 2013). Highly identified employees also promote the organization through various activities, specifically by making financial contributions to the organization, advising their children and others to join the organization, and engaging in organizational activities (e.g., attending organizational events; Mael \& Ashforth, 1992). Furthermore, organizational 
members who identify with their organization are more likely to support their organization in the future (Myers et al., 2016).

\section{Summary}

Organizational identification has been examined by organizational researchers across several disciplines, most notably organizational psychology and organizational communication. Organizational identification is directly linked with member integration into an organization and benefits both the organization and its workers. As organizational members become integrated into the organization, they may develop a mentor-protégé relationship. The second section of this chapter addresses mentor-protégé relationships within the workplace.

\section{Mentor-Protégé Relationships}

Within the workplace, individuals develop and maintain relationships with other organizational members that aid in career development (i.e., developmental relationships), which are known as mentor-protégé relationships. These relationships are a specific type of developmental relationship in which a higher-ranking organizational member provides assistance and guidance to a lower-ranking organizational member, with the goal of providing the lower-ranking individual with career support and opportunity for professional advancement (Ragins \& Cotton, 1999). Although individuals usually develop mentor-protégé relationships representative of this conceptualization, relationships with other organizational members (i.e., peers) that provide them with the same functions are equally beneficial (Higgins \& Kram, 2001; Kram, 1988; Kram \& Isabella, 1985; Lankau, \& Scandura, 2001). Regardless of the composition of the relationship, however, communication between mentors and protégés often is aimed 
toward the guidance and support of the protégés' career development (Hill, Bahniuk, \& Dobos, 1989) through the provision of social support, task assistance, and information pertaining to job roles and organizational rules (Bahniuk, Dobos, \& Hill, 1990; Hill, Bahniuk, Dobos, \& Rouner, 1989).

Mentors and protégés may be assigned to the mentor-protégé relationship formally through organizational mentoring programs (i.e., formal mentor-protégé relationships), or the relationship may develop as the mentor recognizes career potential in the protégé and the protégé recognizes the mentor's potential to provide developmental support (i.e., informal mentor-protégé relationships; Gaskill, 1993; Ragins \& Cotton, 1999). Organizations generally benefit from assigning formal mentor-protégé relationships to organizational newcomers, as these relationships help socialize newcomers, increase protégé performance, identify employees who exhibit potential for success within the organization, and increase diversity and effective communication between managers and lower-level employees (Baugh \& Fagenson-Eland, 2007). Although both formal and informal mentor-protégé relationships are beneficial to organizations as well as to both mentors and protégés, mentor-protégé relationships that are initiated and developed informally provide a greater amount of these benefits than do formal relationships (Chao, Walz, \& Gardner, 1992; Ragins \& Cotton). Formal and informal mentor-protégé relationships differ based on how they are initiated, as formal relationships are sanctioned by the organization and informal relationships are initiated by request. Additionally, mentor-protégé relationships formally assigned by the organization typically last up to a year, whereas once established, informal mentorprotégé relationships may develop over three to eight years (Baugh \& Fagenson-Eland; 
Gaskill; Kram, 1983).

Regardless of whether this mentor-protégé relationship develops formally or informally, this relationship consists of four developmental phases: initiation, cultivation, separation, and redefinition (Kram, 1983, 1988). In a typical mentor-protégé relationship, the initiation phase starts in the first six to 12 months of the relationship and is characterized by admiration and respect for the mentor, as the protégé perceives the mentor as caring, supportive, and respectful, whereas the mentor perceives the protégé as someone with whom it is enjoyable to work and someone with potential to advance successfully in his or her career. Beginning in the second year of the relationship, the cultivation phase lasts between two and five years and is marked by testing expectations developed in the initiation phase, as the mentor and protégé begin to provide each other with mutual and reciprocal assistance. The separation phase, which begins between four and seven years after the start of the relationship and lasts between six months and two years, occurs when the protégé becomes more independent and autonomous and the nature and value of the relationship is reassessed by the mentor and protégé. As the need for the mentor-protégé relationship is reassessed, both the mentor and protégé experience turmoil and anxiety as they outgrow the relationship. The redefinition phase, which redefines the mentor-protégé relationship, is characterized by a transition to friendship and feelings of gratitude; the new relationship no longer provides the protégé the same assistance and guidance as the mentor-protégé relationship once did.

Within the organizational management research, $\operatorname{Kram}(1983,1988)$ was the first researcher who identified the specific functions mentor-protégé relationships serve, distinguishing these developmental relationships from other workplace relationships. She 
argued that these relationships are able to serve both mentors and protégés with career development and psychosocial functions. Although other researchers have identified similar mentoring functions that overlap with Kram's (1983) career development and psychosocial functions (Fowler \& O'Gorman, 20015; Noe, 1988; Schockett \& HaringHidore, 1985; Tepper, Shaffer, \& Tepper, 1996), Kram's labels are the most commonly used labels to describe these functions.

The fulfillment of career development and psychosocial functions by mentors is associated with a positive effect on protégés. In addition to increasing protégés' satisfaction with the mentor-protégé relationship (Waldeck, Orrego, Plax, \& Kearney, 1997), the benefits of the provision of both mentoring functions extend outside of the relationship. For example, protégés with mentors who fulfill career development and psychosocial functions experience positive job outcomes, such as increased promotion rate, improved compensation, growth in salary, and increased job and career satisfaction (Allen, Eby, Poteet, Lentz, \& Lima, 2004; Scandura, 1992). Both career development and psychosocial functions also enable the integration of workers into the organizational culture (Allen, McManus, \& Russell, 1999), alleviate protégés' job-related stress (Sosik \& Godshalk, 2000), and foster perceptions that the organization has protégés' best interests and needs in mind (Hu, Wang, Yang, \& Wu, 2014).

\section{Career Development Functions}

Kram's $(1983,1988)$ career development functions refer to the specific functions of the mentor-protégé relationship that are targeted toward either hierarchical or career advancement of protégés, which benefits both mentors and protégés. Generally, due to mentors' hierarchical position, they are able to assist protégés by introducing them to 
experiences and opportunities within the organization. These career development functions also enable protégés to develop and maintain relationships with important individuals within the organization (Allen et al., 1999). Mentor-protégé relationships serve five career development functions: sponsorship, exposure and visibility, coaching, protection, and challenging assignments (Kram).

Sponsorship. Sponsorship refers to mentors' public endorsement and support of protégés. Mentors' sponsorship of their protégés is essential for protégés to advance within the organization, as sponsorship involves mentors recommending protégés for advancement opportunities they may otherwise not receive. Although sponsorship may be facilitated through formal advancement or promotional decisions, mentors' informal interactions with influential organizational members can serve as opportunities to sponsor and promote protégés. Protégés' competence and potential is communicated to these influential organizational members, which, along with protégés' association with mentors and positive reputation within the organization, leads to the consideration of protégés for advanced positions and opportunities. Although seemingly only benefitting protégés, sponsorship also is beneficial to mentors, particularly if protégés fulfill their potential. Mentors are perceived favorably for having good judgment, thereby increasing their credibility within the organization. However, if protégés do not fulfill their potential, mentors risk being perceived negatively by other organizational members.

Exposure and visibility. Exposure and visibility refers to assigning responsibilities that increase protégés' association with senior organizational members. Through this function, protégés are able to demonstrate their competence and establish relationships with other more advanced organizational members. Through these 
associations, protégés may be considered for advancement in the future. By being exposed to opportunity and responsibility, protégés are able to learn more about their job and the nature of organizational life at higher levels. Additionally, this function makes protégés more visible to other influential organizational members. Exposure and visibility aids in the socialization of protégés into more advanced organizational roles. However, mentors risk their reputation, particularly if protégés fail, and sacrifice their own exposure and visibility by giving protégés some of their responsibilities.

Coaching. Coaching refers to providing protégés with strategies and advice for career improvement. Through coaching, mentors assist protégés with navigating their career. Early in protégés' careers, mentors provide advice about new positions, as mentors have more experience and can share their perspectives. As protégés continue to develop their careers, they may use their mentors' connections to gain more information and greater understanding about organizational members in positions more advanced in the organizational hierarchy. In comparison to organizational members without mentors, protégés become more knowledgeable about organizational policies and politics. Mentors, in turn, are able to confirm their expertise and knowledge within the organization by passing it to their protégés. Additionally, sharing ideas and perspectives with future organizational generations provides mentors with a sense of self-efficacy and respect from other organizational members.

Protection. Protection refers to mentors guarding protégés from possible negative or adverse contact within the organization. Although visibility is typically a positive function for protégés, protection is beneficial when visibility becomes potentially damaging. For example, if protégés fail or do not know enough to succeed, mentors can 
take responsibility to preserve their own reputations. However, protection may hinder protégés when mentors prevent potentially constructive visibility. That is, mentors protect protégés from risks, but also may protect from exposure and visibility that can benefit them. When mentors protect protégés from risky situations, their reputation is enhanced for intervening when necessary. Protection, however, also may become problematic within cross-sex mentor-protégé relationships. Protection of female protégés in particular may be perceived as inappropriate by other organizational members. Particularly, male mentors may be perceived as protecting female protégés more than they would protect male protégés. Female protégés who receive protection may at times feel like they are not being given all the opportunities they deserve. However, without protection, female protégés may feel like they are not receiving the support needed from their male mentors.

Challenging assignments. Providing challenging assignments refers to assigning tasks that increase protégés' skills and competencies for future development. After accomplishing challenging assignments, protégés also feel accomplished and experience self-efficacy. These opportunities are necessary for protégés' growth, as they receive important feedback on their performance. Challenging assignments helps prepare protégés for more advanced roles within the organization by providing protégés with greater responsibility and opportunities to improve the technical skills required of these advanced roles. By providing protégés with challenging assignments, mentors are relieved of some of their workplace responsibilities. As protégés offer technical support to mentors by fulfilling challenging assignments, the mentor is able to accomplish other tasks. 


\section{Psychosocial Functions}

Kram $(1983,1988)$ posited that mentors serve protégés with psychosocial functions, which refer to functions that assist with protégés' cognitive and social development by increasing their confidence--enabling them to feel more competent in the workplace--and increasing their effectiveness as organizational members. Whereas career development functions are important for career advancement and success, psychosocial functions are more personal and essential for protégés' self-worth, both within and outside of the organization, and specifically help protégés learn job tasks and gain information pertaining to formal and informal power structures within the organization (Allen et al., 1999). These psychosocial functions are role modeling, acceptance and confirmation, counseling, and friendship.

Role modeling. Role modeling refers to mentors serving as an individual protégés aspire to imitate, which can include aspiring to attain a similar organizational role as the mentor or aspiring to mirror mentors' behaviors and values. Through this psychosocial function, protégés are shaped by mentors, becoming similar to their mentors in some ways, while still differentiating themselves in other ways. As such, role modeling enables protégés to generate a stronger sense of self. Additionally, role modeling is beneficial for both mentors and protégés as both individuals feel valued and validated and become emotionally attached to one another. Within cross-sex mentor-protégé relationships, however, role modeling can become problematic. Protégés in cross-sex mentor-protégé relationships typically experience less role modeling than do protégés in same-sex relationships (Scandura \& Williams, 2001), and, particularly among females with male mentors, protégés may experience difficulty perceiving their mentor as a role model 
(Kram, 1988).

Acceptance and confirmation. Acceptance and confirmation refers to mentors encouraging and supporting protégés as they advance within their organization and throughout their careers. Additionally, protégés encourage and support mentors as they reach phases in their career with less opportunity for advancement and creativity. As mentors and protégés provide each other with positive regard, both individuals in the mentor-protégé relationship experience a stronger sense of self and psychological nurturance. Protégés who receive acceptance and confirmation from mentors are generally more trusting of their mentor and willing to take more risks, as they have less fear of rejection. Additionally, mentors feel more valued, needed, and useful. However, mentor-protégé relationships that offer acceptance and confirmation experience more conflict than mentor-protégé relationships that do not, as these individuals are less likely to simply conform when disagreements arise.

Counseling. Counseling refers to providing opportunities for protégés to discuss and resolve personal and professional problems that negatively affect them in the workplace. Protégés and mentors discuss protégés’ anxieties and the challenges preventing protégés from being effective within the organization. Counseling allows for self-exploration, as mentors share their own perspectives to help solve protégés' problems. Early in their career, protégés are concerned with establishing their competence, showcasing their potential, maintaining their individuality, fitting in with other organizational members, and negotiating work responsibilities with other areas of their lives. To help protégés cope with these problems, mentors serve as confidants. Additionally, counseling is beneficial for mentors as they feel helpful by assisting 
protégés with their problems and are able to reflect on their past experiences when doing so.

Friendship. Friendship refers to interacting informally and fostering mutual liking between mentors and protégés. The friendship function allows for protégés to view their mentors as more of a peer than a mentor, which is beneficial to both individuals. Specifically, protégés are able to interact with other organizational members in positions of authority more effectively, whereas mentors enjoy these interactions in which they can relate to their inexperienced and often younger protégés. However, friendships between mentors and protégés can be more difficult to navigate when interactions take place outside of the organization as mentors may experience conflicting expectations of serving both as a mentor and as a friend to their protégés. Additionally, within cross-sex mentorprotégé relationships, friendships may be perceived negatively or as inappropriate by other organizational members.

Collectively, the career development and psychosocial functions that mentors serve can vary based on the formality of the relationship. When compared to formal mentor-protégé relationships, protégés in informal mentor-protégé relationships tend to experience more positive functions. In formal mentor-protégé relationships, mentors serve psychosocial functions more frequently than career development functions (Allen et al., 1999), whereas in informal mentor-protégé relationships, mentors serve career development functions more frequently than psychosocial functions (Chao et al., 1992; Noe, 1988; Ragins \& Cotton, 1999). However, protégés within formal mentor-protégé relationships that fulfill career development functions have greater levels of affective well-being and organizational commitment than those protégés in relationships that do 
not fulfill career development functions (Chun, Sosik, \& Yun, 2012). Mentoring functions also may depend on the nature of the initiation of the relationship. Protégés report mentors who initiated the mentor-protégé relationship as providing greater amounts of career development and psychosocial functions than mentors who did not initiate the mentor-protégé relationship (Mullen, 1998; Scandura \& Williams, 2001; Turban \& Dougherty, 1994).

\section{Summary}

Mentor-protégé relationships may be formally assigned by organizations to promote protégés' socialization, although informal development of these relationships typically provide organizations and protégés with more beneficial outcomes. The functions mentor-protégé relationships serve demonstrate the importance of these relationships to organizations and organizational members. The third section of this chapter details the purpose of, and introduces the context for, this dissertation.

\section{Rationale}

The purpose of this dissertation is to investigate the influence of the mentoring functions superiors (also referred to as supervisors) serve with their subordinates. Studied initially by Jablin (1979), the superior-subordinate relationship is conceptualized as a relationship in which one organizational member has the formal authority to direct and evaluate another organizational member's behavior within the organization. Generally, superiors communicate with their subordinates (i.e., downward communication) to provide instructions, explain job rationale, distribute information pertaining to organizational procedures, offer performance feedback, and foster organizational goal indoctrination, whereas subordinates communicate with their superiors (i.e., upward 
communication) to provide information about themselves, their coworkers, organizational practices, and the needs of the organization (Katz \& Kahn, 1966). Additionally, mentoring is considered to be a function of the superior-subordinate relationship (Sias, 2009).

Organizational communication scholars have examined the superior-subordinate relationship on four levels. These four levels are the individual (i.e., differences between and perceptions of each individual within the relationship) level, the dyadic (i.e., superior-subordinate pairs) level, the workgroup (i.e., the extent to which a superior influences an entire workgroup) level, and the organization (i.e., superiors and subordinates within larger departments or organizations) level (Dansereau \& Markham, 1987). Because the third and fourth levels are not relevant to this dissertation, only the research conducted on the individual (i.e., the first level) and the dyad (i.e., the second level) are reviewed in this section.

\section{The Individual Level}

Generally, the individual level explores how communication within the superiorsubordinate relationship influences the two individuals (i.e., the superior, the subordinate) within the relationship. Ultimately, how superiors communicate with subordinates directly affects subordinates' experience within the organization as the quality of communication with superiors is associated positively with subordinates' organizational commitment (Allen, 1992). Communication satisfaction within the superior-subordinate relationship is associated positively with both superiors' and subordinates' job satisfaction (Steele \& Plenty, 2015). Subordinates' perceptions of their superiors' communication competence and use of expert power positively affects their 
organizational identification (Falcione, 1974; Myers \& Kassing, 1998; Roach, 1998). Additionally, superiors' use of constructive conflict resolution strategies is associated positively with perceived helpfulness of the superior, openness of upward communication, and participation in goal setting (Burke, 1970).

Superiors can employ particular communicative behaviors to enhance their subordinates' work outcomes. For example, when superiors engage in strategies to demonstrate verbal immediacy (i.e., behaviors that decrease physical or psychological distance from subordinates), subordinates feel more emotionally supported by them (Eichorn, Martin, Weber, \& Knapp, 2012). Additionally, subordinates who perceive their superiors as immediate typically are intrinsically motivated, satisfied with their job, and empowered (Kelly \& Westerman, 2014). Similarly, supervisors who use affinity-seeking strategies positively affect subordinates' organizational identification and satisfaction with supervision (Richmond, McCroskey, \& Davis, 1986; Roach, 1998). The quality of communication from superiors also is associated with subordinates' perceptions of their superiors, in that superiors who engage in communicative behaviors that demonstrate persuasiveness and social skills are perceived by their subordinates as credible (Mikkelson, Sloan, \& Hesse, 2017).

Superior feedback can influence subordinates' satisfaction with their superiors. Not surprising, superiors who provide positive feedback to their subordinates motivate them and improve satisfaction with superiors, although negative feedback does not necessarily decrease subordinates' satisfaction with superiors (Jaworski \& Kohli, 1991). Moreover, the nature of feedback provided to subordinates is important to the superiorsubordinate relationship and to subordinates' experiences. Feedback from superiors that 
focuses on specific behaviors and includes setting future goals is associated with higher subordinate job satisfaction and levels of organizational commitment (Tziner \& Latham, 1989).

Along with communication behaviors, specific superior traits influence superior communication and subordinate outcomes. For example, subordinates' perceptions of superior Machiavellianism is associated negatively with perceptions of superior credibility, nonverbal immediacy, responsiveness, and expert power, but associated positively with legitimate power and coercive power (Teven, McCroskey, \& Richmond, 2006). These superiors also elicit more negative attitudes from subordinates toward their superior as well as lesser amounts of subordinate motivation and job satisfaction (Teven et al.). Additionally, subordinates are more committed to their organization and more satisfied with their superiors when these superiors engage in an affirming communicator style (i.e., relaxed, friendly, attentive), and are argumentative, but are not verbally aggressive (Infante \& Gorden, 1991).

The degree to which superiors' and subordinates' perceptions of each other's communication behaviors match (i.e., perceptual congruence) has also been examined within organizational communication research and is associated with positive subordinate experiences. When superiors and subordinates share congruent perceptions regarding the superiors' communication behaviors, subordinates are more satisfied with their superiors and their jobs (Hatfield \& Huseman, 1982; Schnake, Dumler, Cochran, \& Barnett, 1990). Often times, however, superiors and subordinates are unable to accurately predict how other individuals perceive them (Infante \& Gorden, 1979); in fact, superiors typically perceive their communication practices more favorably than do their subordinates 
(Schnake et al.). For example, although subordinates' involvement in decision-making processes is associated positively with their satisfaction (Falcione, 1974), superiors perceive that subordinates have more involvement in decision-making processes than subordinates perceive they do (Infante \& Gorden).

\section{The Dyadic Level}

Superior-subordinate communication examined on a dyadic level focuses on characteristics of the relationship, often in comparison to other dyads or relationships within the organization. Leader-member exchange theory (e.g., Dansereau, Graen, \& Haga, 1975; Graen \& Schiemann, 1978; Graen \& Uhl-Bien, 1991, 1995) proposes that superiors develop differential relationships with their subordinates that vary in terms of quality and influence, which then are categorized into one of three types (i.e., in-group, middle-group, and out-group), although researchers typically focus on exploring the differences between in-group and out-group relationships. In-group relationships are characterized by mutual influence between superiors and subordinates as well as jobrelated support and feedback; out-group relationships are defined based on expectations of the superior-subordinate relationship as dictated by the organization (Graen \& UhlBien, 1995). That is, in-group relationships typically have higher degrees of relational quality, whereas out-group relationships are defined largely by the superiors' and subordinates' roles within the organization.

Generally, higher-quality superior-subordinate relationships (i.e., in-group) are associated with positive work outcomes for both subordinates and superiors in that superiors' communication behaviors are positively linked with employee satisfaction, work group or department identification, and communication satisfaction, but negatively 
linked with willingness to move to another department or work group (Baird \& Bradley, 1978; Lamude, Scudder, Simmons, \& Torres, 2004; Mueller \& Lee, 2002). More open communication within the superior-subordinate relationship is associated positively with subordinates' satisfaction, specifically satisfaction with their jobs, company, supervisor, and performance appraisals (Burke \& Wilcox, 1969). In-group subordinates also perceive their superiors as engaging in high person-centered communication (Fix \& Sias, 2006). The degree of trust subordinates have in their superiors is associated positively with the extent to which subordinates engage in upward communication; those subordinates who distrust their superiors are more likely to withhold information from these superiors (Roberts \& O’Reilly, 1974).

A higher-quality superior-subordinate relationship also influences the manner in which subordinates express their disagreement within the workplace. Subordinates in ingroup relationships more frequently engage in upward dissent, whereas subordinates in out-group relationships tend to more frequently engage in lateral dissent (Kassing, 2000b). Similarly, subordinates in in-group relationships tend to use relational upward influence tactics more frequently, which in turn promotes superiors' positive perceptions of subordinate performance (Geertshuis, Morrison, \& Cooper-Thomas, 2015).

Furthermore, subordinates in in-group relationships are more open and direct and less manipulative with their upward influence tactics (Krone, 1991).

\section{Hypothesis One}

Collectively, then, it is not surprising that superiors' behavior toward their subordinates can influence subordinates' degrees of organizational identification. For example, superiors' use of affinity-seeking strategies and managerial styles that view 
employees as responsible, creative, and intelligent tend to foster subordinates' organizational identification (Roach, 1998). Additionally, subordinates who perceive their superiors as competent and involved communicators have higher levels of organizational identification (Myers \& Kassing, 1998). Among graduate students, advising from a mentor and lack of relational clashes with that mentor are associated with higher organizational identification (Bullis \& Bach, 1989a). Highly identified employees tend to perceive messages from management as effective (Stephens, Goins, \& Dailey, 2014) and are more likely to discuss these messages with others within the organization (Stephens et al., 2015). However, inappropriate and impersonal communication from management conveyed through one-way computer-mediated communication channels is associated with decreased organizational identification (Larson \& Pepper, 2011). Furthermore, within mentor-protégé relationships, the career development functions allow protégés to become more integrated and successful within the organization, and the psychosocial functions are inherently linked with protégés' self-worth and confidence; these mentoring functions bolster protégés' integration within the organizational hierarchy and self-esteem within the organization (Kram, 1983, 1988), potentially affecting positively the extent to which protégés align with the organization's values and goals. Therefore, the first hypothesis is posited:

H1: Subordinates who perceive their superiors as enacting (a) the five career development mentoring functions (i.e., sponsorship, exposure and visibility, coaching, protection, and challenging assignments) and (b) the four psychosocial mentoring functions (i.e., role modeling, acceptance and confirmation, counseling, and friendship) will more highly identify with 
their organization.

\section{Hypotheses Two and Three}

Job satisfaction, communication satisfaction with superiors, and organizational commitment among employees are three variables that benefit organizations in several ways. ${ }^{1}$ Job satisfaction refers to subordinates' general affect for, or attitude toward, either their work or a specific aspect of their job (Brayfield \& Rothe, 1951; V. E. Wheeless, Wheeless, \& Howard, 1983). Although individuals who are satisfied with their jobs generally are more proficient at their jobs (Judge, Thoresen, Bono, \& Patton, 2001), it is the relationships that they establish with their superiors that is linked directly to whether they are satisfied with their jobs (Kim, 2002; Pincus, 1986; L. R. Wheeless, Wheeless, \& Howard, 1984; V. E. Wheeless et al.). Communication and relationship quality between superiors and subordinates is associated positively with job satisfaction (Fix \& Sias, 2006; Frone \& Major, 1988; Stringer, 2006). Individuals with superiors who facilitate their participation in decision-making, allow for job autonomy, and provide support also are more satisfied with their jobs (Griffin, Patterson, \& West, 2001; Kim, 2002).

Communication satisfaction with superiors refers to an individual's overall affective response to upward and downward communication with a superior (Downs \& Hazen, 1977; Hecht, 1978). Subordinates who are communicatively satisfied with their communication with their superiors are satisfied with their jobs (Steele \& Plenty, 2015; L. R. Wheeless et al., 1984; V. E. Wheeless et al., 1983), are more proficient at their jobs (Pincus, 1986), and are more committed to the workplace (Postmes, Tanis, \& de Wit, 2001). They also perceive these superiors to be communicatively competent and rate these relationships as high quality (Lamude et al., 2004; Mueller \& Lee, 2002; Steele \& 
Plenty). Conversely, superiors who are perceived as verbally aggressive decrease their subordinates' communication satisfaction (Madlock \& Kennedy-Lightsey, 2010).

Organizational commitment refers to an individual's involvement in, and identification with, the organization's goals, which traditionally requires workers to accept the organization's values, behave on behalf of the organization, exhibit a desire to maintain their organizational membership, and internalize the values and goals of the workplace (Mowday, Steers, \& Porter, 1979; O’Reilly \& Chatman, 1986; Porter, Steers, Mowday, \& Boulian, 1974). Organizational commitment also can be viewed in terms of the resources subordinates perceive that their organizations provide for them (e.g., organizational support; van Knippenberg \& Sleebos, 2006; Wayne, Shore, \& Liden, 1997). Generally, individuals committed to their organization are motivated to persist within their organization and are unlikely to leave their jobs (Allen \& Meyer, 1990; Rusbult \& Farrell, 1983; Shore \& Martin, 1989), which explains why organizational commitment is linked positively with job involvement, job satisfaction, intrinsic motivation, perceptions of communication quality with management and superiors, and organizational communication satisfaction (Allen, 1992; Mikkelson, York, \& Arritola, 2015; Mowday et al.; Varona, 1996). Moreover, individuals who are socialized within their organization, interact with other organizational members, and communicate positively about the organization are typically highly committed to their organization (Eisenberg, Monge, \& Miller, 1983; Madlock \& Chory, 2014; Madlock \& Horan, 2009). In summary, subordinates with increased job satisfaction, communication satisfaction, and organizational commitment typically have positive work outcomes. Moreover, subordinates' organizational identification is associated positively with their 
job satisfaction and organizational commitment (Mael \& Tetrick, 1992; Riketta, 2005). Although the relationship between organizational identification and communication satisfaction with superiors has not directly been investigated, previous research findings suggest that perceptions of communication with superiors impacts subordinates' organizational identification. For example, in-group superior-subordinate relationships are associated with increased organizational identification (Sollitto, Martin, Dusic, Gibbons, \& Wagenhouser, 2016) and superiors who are more competent communicators have more highly identified subordinates (Myers \& Kassing, 1998). Therefore, the quality of communication from superiors should be associated positively with subordinates' organizational identification. In line with these findings, the second hypothesis is posited:

H2: Subordinate organizational identification will be associated positively with (a) job satisfaction, (b) communication satisfaction with superiors, and (c) organizational commitment.

Similarly, mentoring functions promote positive work outcomes for protégés. For example, career development and psychosocial mentoring functions are associated with protégés' increased job satisfaction, communication satisfaction with superiors, and organizational commitment (Aryee \& Chay, 1994; Chao et al., 1992; Madlock \& Kennedy-Lightsey, 2010). In the context of this dissertation, subordinates who receive mentoring from their superiors should report the same positive work outcomes as mentored protégés. Therefore, the third hypothesis is proposed:

H3: Subordinate perceptions of superiors' enactment of (a) the five career development mentoring functions (i.e., sponsorship, exposure and 
visibility, coaching, protection, and challenging assignments) and (b) the four psychosocial mentoring functions (i.e., role modeling, acceptance and confirmation, counseling, and friendship) will be associated positively with subordinates' (a) job satisfaction, (b) communication satisfaction with superiors, and (c) organizational commitment.

\section{Hypothesis Four}

In addition to the relationships between mentoring functions, organizational identification, and employee work outcomes, a mediation model situating organizational identification as a mediator between superiors' mentoring and subordinates' workplace outcomes is proposed for two reasons. First, organizational identification has been found to mediate the relationship between employees' perceived organizational support and their organizational commitment, job satisfaction, and intention to leave (Ngo, Loi, Foley, Zheng, \& Zhang, 2013), suggesting that the benefits and psychological safety individuals receive from their organization allows them to identify more with the organization. That is, specific organizational variables (e.g., perceived organizational support) create conditions in which employees are likely to identify with their organization, and in turn, enhance positive work outcomes.

Second, organizational identification has been positioned as the causal mechanism through which superiors' communication influences subordinate outcomes. Leadership behaviors, specifically transformational leadership (Carmeli, Atwater, \& Levi, 2011; Epitropaki \& Martin, 2005) and ethical leadership (Walumbwa et al., 2011) are suggested to increase subordinates' organizational identification, which, in turn, enhances job performance. Leader-member exchange theory (LMX) provides theoretical support for 
the causal role organizational identification plays in the proposed relationship between superiors' communication and subordinates' work outcomes. Although LMX research suggests that in-group relationships are associated with subordinate performance ratings and objective performance metrics, high-quality superior-subordinate relationships also positively influence subordinates' attitudes toward the organization, including overall satisfaction and organizational commitment (Gerstner \& Day, 1997). The quality of superior-subordinate relationships may create conditions in which subordinates more highly identify with their organization. Typically, subordinates perceive their superiors as representative of the organization (Eisenberger et al., 2010), which provides subordinates with perceptions of appropriate behavior within the organization. Additionally, as individuals are motivated to identify with their organization to reduce uncertainty and increase self-esteem (Hogg \& Terry, 2000), superiors who also act as mentors help satisfy these needs (e.g., Kram, 1983). As these needs are satisfied through superiors' mentoring behaviors, it follows that superior-subordinate relationships should be tied directly to organizational identification (Loi, Chan, \& Lam, 2014).

Relatedly, LMX has been examined from a social exchange perspective, suggesting that the resources subordinates perceive from their superiors and organizations lead them to feel, in some way, indebted to the organization. As superiors within in-group relationships provide subordinates with resources and support, subordinates perceive the organization as providing these resources and support as well (Wayne et al., 1997). These higher quality relationships reduce uncertainty, increase self-enhancement, and lead to emotional attachment to the organization (Graen \& Uhl-Bien,1995). If subordinates perceive the organization as valuing and caring about them, they in turn value their 
organization and are more committed to the organization (Wayne et al., 1997).

Although this dissertation does not directly examine LMX relationships, mentoring within the superior-subordinate relationship shares relational qualities with ingroup relationships. Mentoring provides protégés with a supportive relationship that increases their connection and affiliation with other organizational members (i.e., their mentor). Additionally, as protégés feel valued and appreciated, and as they seemingly have approval and increased esteem through the mentoring provided by their superiors, they may experience increased identification with their organizations. In fact, there is evidence that a causal relationship exists between mentoring and organizational identification among protégés. Bullis and Bach (1989a) conducted a longitudinal study examining mentoring and organizational identification between graduate students and their advisors. They found that advising from mentors (i.e., advisors) is associated with increased protégé (i.e., graduate student) organizational identification over time, whereas relational clashes between mentors and protégés are associated with decreased protégé organizational identification over time.

As the support individuals receive, as well as specific superior behaviors (i.e., mentoring), increase organizational identification, this dissertation examines the relationship between superiors' mentoring functions and subordinate organizational identification. Furthermore, as mentoring functions are associated with positive work outcomes, perhaps the relationship between mentoring functions and work outcomes can be explained by the increase of organizational identification caused by mentoring. That is, subordinates who are mentored by their superiors subsequently fulfill their need to belong and more strongly identify with their organization. Their increased identification, 
in turn, generally promotes a more positive workplace experience, as indicated by increased job satisfaction, communication satisfaction with their superiors, and organizational commitment (see Figure 1). Therefore, the fourth hypothesis is proposed:

H4: The effect of subordinate perceptions of superiors' enactment of (a) the five career development mentoring functions (i.e., sponsorship, exposure and visibility, coaching, protection, and challenging assignments) and (b) the four psychosocial mentoring functions (i.e., role modeling, acceptance and confirmation, counseling, and friendship) on subordinate (a) job satisfaction, (b) communication satisfaction with their superior, and (c) organizational commitment is mediated by subordinates' organizational identification.

\section{Summary}

This purpose of this dissertation is to examine the impact superiors' mentoring behaviors have on their subordinates' organizational identification and subsequent work outcomes. Individuals who experience mentoring within their organization tend to have more positive work outcomes, including increased organizational identification. The proposed mediation model situates organizational identification as a mediator of the positive relationship between superiors' mentoring functions (i.e., career development and psychosocial) and positive work outcomes (i.e., job satisfaction, communication satisfaction with superiors, and organizational commitment). That is, superiors who mentor their subordinates may increase subordinates' organizational identification, which then positively impacts subordinates' work outcomes. 
Figure 1

Proposed Mediation Model

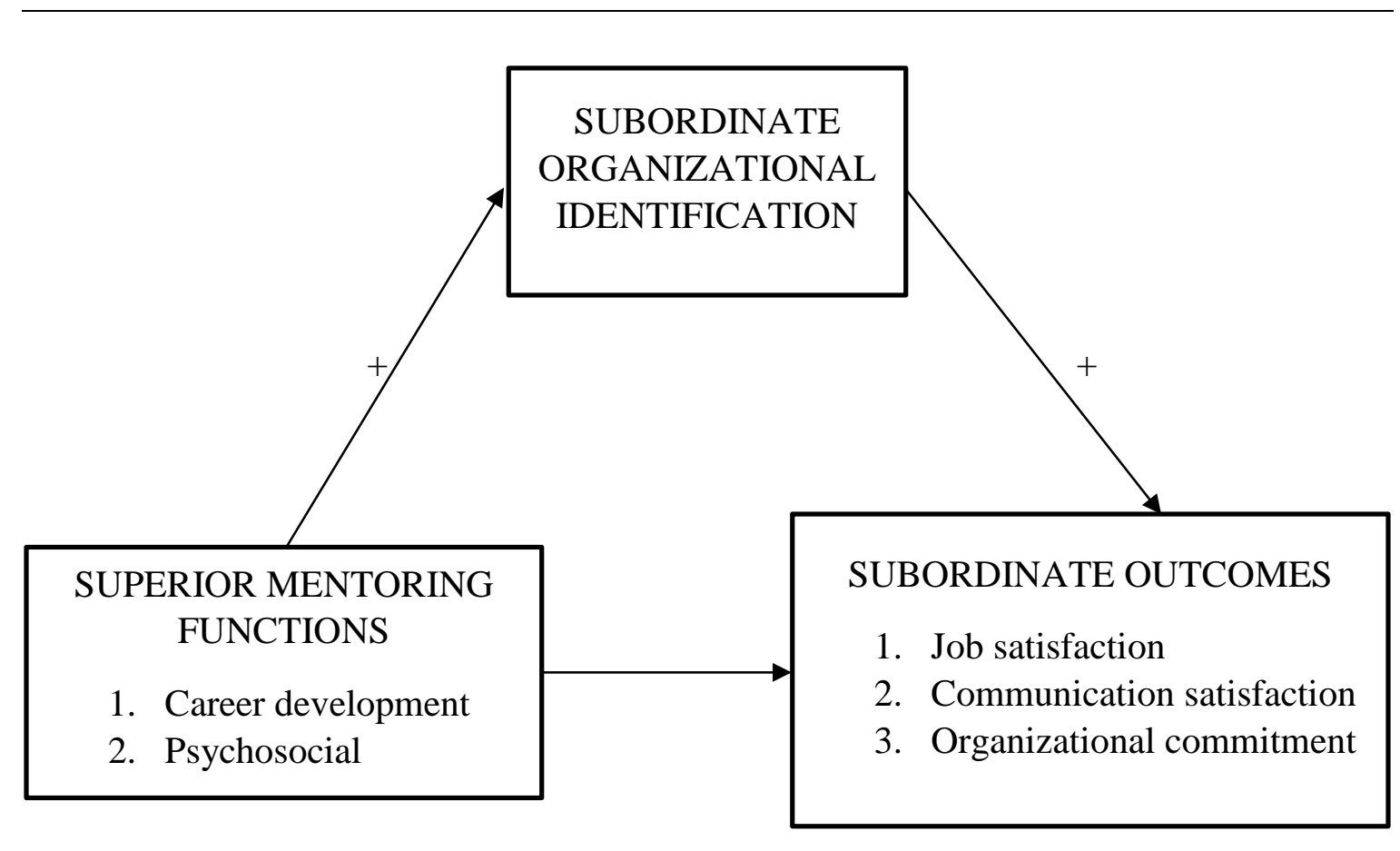

Note. + indicates a predicted positive relationship between the variables. 


\section{CHAPTER II}

\section{Method}

Data were collected for this dissertation from fully-employed adults who were asked to report on their experiences with their current supervisor. This chapter is divided into three sections. The first section describes the participants included in this study as well as the superiors on whom the participants reported. The second section provides a description of the procedures and the survey instrument used to measure the study variables. The third section details the preliminary and primary analyses conducted to address the four hypotheses.

\section{Participants}

Participants were 300 (179 male, 121 female) fully employed (i.e., worked at least 35 hours a week; Cappelli \& Keller, 2013) adults. They were between the ages of 20 and 72 years $(M=36.43, S D=10.54)$. One hundred and sixty-one participants $(n=161)$ reported their ethnicity as white/Caucasian, 104 participants reported their ethnicity as Asian/Asian American, 17 participants reported their ethnicity as Black/African American, 13 participants reported their ethnicity as Hispanic, 4 participants reported their ethnicity as Native American, and 1 participant failed to report his or her ethnicity. The majority of participants $(n=212)$ worked in the United States (see Table 1).

On average, these participants had 15 years $(M=15.20, S D=10.90$, range $=1-56$ years) of work experience across a variety of industries (see Table 2), had worked within their organization for six years $(M=6.41, S D=5.02$, range $=6$ months-27 years $)$, and had worked in their current position for almost five years $(M=4.95, S D=3.75$, range $=6$ months-22 years). Using Kassing's (2000a, 2000b) classification of management levels, 
Table 1

Countries Represented in Sample $(N=300)$

\begin{tabular}{llc}
\hline Industry & $n$ & $\%$ \\
\hline Argentina & 1 & 0.3 \\
Canada & 1 & 0.3 \\
Costa Rica & 1 & 0.3 \\
Dominican Republic & 1 & 0.3 \\
Greece & 1 & 0.3 \\
India & 76 & 25.3 \\
Malaysia & 1 & 0.3 \\
Pakistan & 1 & 0.3 \\
Philippines & 1 & 0.3 \\
Portugal & 1 & 0.3 \\
Sweden & 1 & 0.3 \\
United Arab Emirates & 1 & 0.3 \\
United States of America & 212 & 70.7 \\
Venezuela & 1 & 0.3 \\
& & \\
\hline Note. Tota & 1 & \\
\hline
\end{tabular}

Note. Total of percentages does not equal $100 \%$ due to rounding. 
Table 2

Industries Represented in Sample $(N=300)$

\begin{tabular}{|c|c|c|}
\hline Industry & $n$ & $\%$ \\
\hline Advertising & 6 & 2.0 \\
\hline Agriculture & 1 & 0.3 \\
\hline Arts and entertainment & 12 & 4.0 \\
\hline Banking/Financial services & 25 & 8.3 \\
\hline Computer/Information technology & 52 & 17.3 \\
\hline Construction & 12 & 4.0 \\
\hline Consulting & 1 & 0.3 \\
\hline Education & 32 & 10.7 \\
\hline Engineering & 9 & 3.0 \\
\hline Food service & 9 & 3.0 \\
\hline Government/public service & 12 & 4.0 \\
\hline Health care & 25 & 8.3 \\
\hline Insurance & 5 & 1.7 \\
\hline Journalism/media & 1 & 0.3 \\
\hline Law enforcement & 1 & 0.3 \\
\hline Manufacturing & 26 & 8.7 \\
\hline Nonprofit & 4 & 1.3 \\
\hline Oil and petroleum & 1 & 0.3 \\
\hline Private security & 1 & 0.3 \\
\hline Real estate & 3 & 1.0 \\
\hline Recreation & 1 & 0.3 \\
\hline Retail sales & 14 & 4.7 \\
\hline Sales & 16 & 5.3 \\
\hline Service industry & 17 & 5.7 \\
\hline Telecommunications & 8 & 2.7 \\
\hline Transportation & 6 & 2.0 \\
\hline
\end{tabular}

Note. Total of percentages does not equal $100 \%$ due to rounding. 
7 participants identified their current organizational position as top management, 128 participants identified their current organizational position as management, and 162 participants identified their current organizational position as nonmanagement. Three participants did not specify their level of management. Of the 300 participants, 94 $(31.3 \%)$ reported that they telecommute to their workplace.

Participants reported working for 185 male and 115 female supervisors. The majority of supervisors $(n=172)$ was identified as White/Caucasian, with 89 supervisors identified as Asian/Asian American, 16 supervisors identified as Hispanic, 14 supervisors identified as Black/African American, 5 supervisors identified as Native American, and 3 supervisors identified as Middle Eastern. (One participant did not specify his or her supervisor's ethnicity.) On average, participants and their supervisors had worked together for four years $(M=4.12, S D=3.02$; range $=4$ months-18 years $)$.

\section{Procedure and Instrumentation}

Upon receiving Institutional Review Board approval, data were collected using Amazon's online labor market, Mechanical Turk (MTurk). Through MTurk, workers (i.e., research participants) are hired to complete "tasks" (e.g., online surveys) for monetary compensation by selecting those tasks they wish to complete for specified compensation rates. MTurk is becoming an accepted practice for soliciting research participants among organizational communication scholars (Mikkelson et al., 2017; Mikkelson et al., 2015; Veksler \& Boren, 2017). Participants recruited using MTurk typically are more demographically diverse and more representative of non-college samples than other online Internet recruitment procedures (Buhrmester, Kwang, \& Gosling, 2011; Paolacci \& Chandler, 2014). Due to the length of the questionnaire used 
in this dissertation, participants were compensated 50 cents to complete the questionnaire. This rate is a suggested compensation rate for lengthy surveys, as it provides enough monetary incentive for workers to complete the survey (Buhrmester et al.).

Participants first were presented with an advertisement for the study on MTurk (see Appendix A). Following the procedures utilized in prior organizational communication studies (Myers \& Johnson, 2004; Myers, Knox, Pawlowski, \& Ropog, 1999; Sollitto \& Myers, 2015), to be included in the sample, individuals had to be organizational workers over the age of 18 who had a direct supervisor and who were not currently enrolled as a college student on either a part- or full-time basis. Individuals who met this inclusion criteria and who agreed to participate were directed to a cover letter explaining the nature of the study (see Appendix B). ${ }^{2}$ They then were directed to a Qualtrics online questionnaire (see Appendix C) that included the Shortened Organizational Identification Questionnaire (Miller, Allen, Casey, \& Johnson, 2000); the sponsorship, exposure, coaching, protection, challenging assignments, role modeling, acceptance, counseling, and friendship subscales of the Mentor Role Instrument (Ragins \& McFarlin, 1990); the Abridged Job in General Scale (Russell et al., 2004); the Interpersonal Communication Satisfaction Inventory (Hecht, 1978); and the Organizational Commitment Questionnaire (Mowday et al., 1979). All items on the questionnaire were measured using a 7-point Likert scale ranging from 1 (strongly disagree) to 7 (strongly agree). Specific items designed to ensure participants were providing meaningful responses to the survey questions (i.e., as a data quality control measure) were added throughout the survey instrument (Sheehan \& Pittman, 2016). ${ }^{3}$ 
Participants then reported demographic information previously assessed in organizational communication research (Kassing, 2000a, 2000b), including their sex, age, ethnicity, years of work experience, length of employment at their current organization, the length of employment in their current position, their level of management, and whether they telecommute to work. Participants also identified the industry within which they work and the country in which their organization was located as well as their direct supervisor's demographics (i.e., sex, age, and ethnicity) and the length of their work relationship with their superior.

The Shortened Organizational Identification Questionnaire is a 12-item instrument measuring participants' membership, loyalty, and similarity to their organization (see Appendix D). Sample items include "I am proud to be an employee of this organization" and "I am glad I chose to work for this organization rather than another company.” Previous Cronbach's alpha reliability coefficients ranging from .88 to .97 have been obtained for this instrument (Ju \& Shoham, 2017; Miller et al., 2000). A filler item (i.e., "The earth has three moons") was added to the instrument as a data quality control measure.

The Mentor Role Instrument is a 33-item instrument measuring perceptions of mentoring functions, with three items measuring each of the five career development mentoring functions (i.e., sponsorship, exposure and visibility, coaching, protection, and challenging assignments; 15 items) and each of the four psychosocial mentoring functions (i.e., role modeling, acceptance and confirmation, counseling, and friendship; 12 items), as well as three items each measuring Kram's (1988) social and parent roles (six items). Because this dissertation focused only on the career development and 
psychosocial mentoring functions, the social and parent subscales were not used (27 items; see Appendix E). Sample items include "My supervisor helps me attain desirable positions" (sponsorship), "My supervisor helps me be more visible in the organization" (exposure and visibility), "My supervisor suggests specific strategies for achieving career aspirations" (coaching), "My supervisor 'runs interference' for me in the organization" (protection), "My supervisor provides me with challenging assignments" (challenging assignments), "My supervisor serves as a role model for me" (role modeling), "My supervisor accepts me as a competent professional" (acceptance and confirmation), "My supervisor guides my personal development" (counseling), and "My supervisor is someone I can confide in" (friendship). Previous Cronbach's alpha reliability coefficients ranging from .74 to .97 for the five career development functions and ranging from .63 to .94 for the four psychosocial functions have been obtained (Dilmore et al., 2010; Ragins \& Cotton, 1999). A filler item (i.e., "Please select Strongly Agree") was added to the instrument as a data quality control measure.

The Abridged Job in General Scale is an 8-item instrument measuring individuals' satisfaction with, or affect toward, their job (see Appendix F). The original response format for this instrument used yes, ?, and no response categories, which was modified to a 7-point Likert scale in this dissertation. Sample items include "My job is enjoyable” and "My job makes me content." Previous Cronbach's alpha reliability coefficients ranging from .92 to .96 have been obtained for this instrument (Mikkelson et al., 2015; Steele \& Plenty, 2015).

The Interpersonal Communication Satisfaction Inventory is a 19-item instrument measuring individuals' satisfaction with communication with a conversational partner 
(see Appendix G). In this dissertation, all 19 items were modified to fit the context of the superior-subordinate relationship. Sample modified items include "When communicating with my immediate supervisor, I feel he or she lets me know that I am communicating effectively" and "When communicating with my immediate supervisor, I feel he or she genuinely wants to get to know me better." Previous Cronbach's alpha reliability coefficients ranging from .81 to .93 have been obtained for this instrument used in organizational communication studies (Madlock \& Kennedy-Lightsey, 2010; Steele \& Plenty, 2015). A filler item (i.e., "A kangaroo is a whale") was added to the instrument as a data quality control measure.

The Organizational Commitment Questionnaire is a 15-item instrument measuring individuals' commitment to their organization (see Appendix H). Sample items include "I am willing to put in a great deal of effort beyond that normally expected in order to help this organization be successful" and "I would accept almost any type of job assignment in order to keep working for this organization." Previous Cronbach's alpha reliability coefficients ranging from .88 to .94 have been obtained for this instrument (Mikkelson et al., 2015; Reed et al., 2016). A filler item (i.e., "I do not understand a word of English") was added to the instrument as a data quality control measure.

\section{Data Analysis}

To address the four hypotheses, preliminary and primary analyses were conducted. The following sections outline these analyses.

Preliminary analyses. Prior to testing the hypotheses, preliminary reliability analyses and correlational analyses were conducted for all survey instruments. Reliability 
analysis indicates the consistency of an instrument across samples, with higher reliability coefficients indicating lower measurement error (Cronbach, 1951; Field, 2011). A Cronbach's alpha reliability analysis was conducted on all the instruments. Correlational analysis indicates whether a linear relationship exists between two continuous variables (Keyton, 2011). A series of two-tailed Pearson Product-Moment correlations was conducted among all the variables to determine both the direction and the magnitude of the relationships that exist among the variables.

Primary analyses. Before assessing hypotheses one, two, and three, a series of independent samples $t$-tests was conducted to determine if participants' reports of their organizational identification, their perceptions of their superiors' use of the five career development mentoring functions and the four psychosocial mentoring functions, and their reports of job satisfaction, communication satisfaction, and organizational commitment fluctuated based on workplace characteristics (i.e., their length of time working for their organization, length of time working in their current position, length of time working with their current supervisor, telecommuter status, and country in which their organization is located). These workplace characteristics then served as control variables used to address hypotheses one, two, and three, which were assessed using a series of partial correlations. A partial correlation examines a relationship between two variables while controlling for another variable or variables (Frey, Botan, \& Kreps 2000).

To address the fourth hypothesis, three series of simple mediation models using Ordinary Least Squares path analysis were conducted. A simple mediation model determines a variable's effect on an outcome variable through its effect on a dependent variable (Hayes, 2013). Using Model 4 of Hayes’s PROCESS macro for SPSS, a 95\% 
percentile bootstrapped confidence interval for 10,000 bootstrap estimates determines evidence of an indirect effect; a confidence interval completely excluding 0 indicates evidence of an indirect effect of mentoring functions on subordinate outcomes through the effect of mentoring on organizational identification. Path coefficients represent the estimate of the effect of mentoring functions on organizational identification $(a)$, the effect of organizational identification on subordinate outcomes controlling for mentoring functions (b), and the effect of mentoring functions on subordinate outcomes controlling for organizational identification $\left(c^{\prime}\right)$. The total effect of mentoring functions on subordinate outcomes $(c)$ indicates the extent to which subordinate outcomes are impacted by a one unit change in mentoring functions, and the indirect effect $(a b)$ and the completely standardized indirect effect $\left(a b_{c s}\right)$ indicate the extent to which subordinate outcomes are impacted by changes in mentoring functions through organizational identification. This sample size is above the minimum sample size needed to detect moderate effects (i.e., .39) at .80 power when testing a mediation model (Fritz \& MacKinnon, 2007).

\section{Summary}

Paid voluntary participants completed self-report measures pertaining to their direct superior and their work outcomes. This chapter provided a description of the participants included in the sample and of the supervisors on which participants reported, an overview of recruitment and data collection procedures employed, and a review of the self-report instruments used to measure study variables. Additionally, the preliminary analyses and the primary analyses used to test the four hypotheses were described. 


\section{CHAPTER III}

Results

As a preliminary analysis of the data, Cronbach's alpha reliability coefficient analysis and two-tailed correlation analysis were conducted. Partial correlational analyses were employed to address hypotheses one, two, and three. To address hypothesis four, three series of simple mediation analyses were conducted. This chapter reports the results of the preliminary analyses, as well as the primary analyses used to address the four hypotheses.

\section{Preliminary Analyses}

\section{Cronbach's Alpha Reliability Coefficient Analysis}

The mean score, the standard deviation score, and Cronbach's alpha reliability coefficient were calculated for each of the instruments used in this dissertation. Across the instruments, the Cronbach's alpha reliability coefficients ranged between .86 and .98 , which demonstrates acceptable internal consistency of all survey instruments (Keyton, 2011). Table 3 displays the Cronbach's alpha reliability coefficient, the number of items, the item scale ranges, the theoretical response scale ranges, the mean score, and the standard deviation score for each instrument.

\section{Two-Tailed Correlation Analysis}

A series of two-tailed Pearson Product-Moment correlation analyses was conducted to determine the direction and magnitude of the relationships that exist between each variable. Table 4 contains a correlation matrix of these variables. 
Table 3

Instrument Information

\begin{tabular}{|c|c|c|c|c|c|c|}
\hline Instrument & $\alpha$ & $\begin{array}{l}\text { Number } \\
\text { of Items }\end{array}$ & $\begin{array}{l}\text { Item } \\
\text { Scale } \\
\text { Range }\end{array}$ & $\begin{array}{c}\text { Theoretical } \\
\text { Response } \\
\text { Range }\end{array}$ & $M$ & $S D$ \\
\hline Identification & .98 & 12 & $1-7$ & $12-84$ & 5.12 & 1.49 \\
\hline \multicolumn{7}{|c|}{ Career Development Mentoring Functions } \\
\hline Sponsorship & .91 & 3 & $1-7$ & $3-21$ & 4.87 & 1.42 \\
\hline Exposure & .92 & 3 & $1-7$ & $3-21$ & 4.92 & 1.48 \\
\hline Coaching & .91 & 3 & $1-7$ & $3-21$ & 4.99 & 1.47 \\
\hline Protection & .86 & 3 & $1-7$ & $3-21$ & 4.50 & 1.40 \\
\hline Assignments & .91 & 3 & $1-7$ & $3-21$ & 5.28 & 1.38 \\
\hline \multicolumn{7}{|c|}{ Psychosocial Mentoring Functions } \\
\hline Role Modeling & .93 & 3 & $1-7$ & $3-21$ & 4.82 & 1.63 \\
\hline Acceptance & .88 & 3 & $1-7$ & $3-21$ & 5.43 & 1.22 \\
\hline Counseling & .93 & 3 & $1-7$ & $3-21$ & 4.88 & 1.57 \\
\hline Friendship & .91 & 3 & $1-7$ & $3-21$ & 5.18 & 1.46 \\
\hline \multicolumn{7}{|l|}{ Workplace Outcomes } \\
\hline Job Satisfaction & .94 & 8 & $1-7$ & $8-28$ & 5.40 & 1.33 \\
\hline Comm Satisfaction & .93 & 19 & $1-7$ & $19-133$ & 5.05 & 1.06 \\
\hline Org Commitment & .92 & 15 & $1-7$ & $15-105$ & 4.81 & 1.24 \\
\hline
\end{tabular}

Note. The endpoints of all the instruments are strongly disagree (1) and strongly agree (7). Identification $=$ organizational identification. Exposure $=$ exposure and visibility. Assignments $=$ challenging assignments. Acceptance $=$ acceptance and confirmation. Comm satisfaction $=$ communication satisfaction. Org commitment $=$ organizational commitment. 
Table 4

\section{Correlation Matrix}

$\begin{array}{lllllllllllll}\text { Variable } & 1 & 2 & 3 & 4 & 5 & 6 & 7 & 8 & 10 & 11 & 9 & \end{array}$

1. Identification

Career Development Mentoring Functions

$\begin{array}{lllllll}\text { 2. Sponsorship } & .77 & -- & & & & \\ \text { 3. Exposure } & .76 & .83 & -- & & & \\ \text { 4. Coaching } & .74 & .82 & .81 & -- & & \\ \text { 5. Protection } & .64 & .73 & .76 & .69 & -- & \\ \text { 6. Assignments } & .72 & .75 & .77 & .77 & .61 & --\end{array}$

Psychosocial Mentoring Functions

$\begin{array}{lllllllllll}\text { 7. Role Modeling } & .77 & .82 & .82 & .81 & .72 & .73 & -- & & \\ \text { 8. Acceptance } & .71 & .70 & .66 & .62 & .56 & .67 & .70 & -- & & \\ \text { 9. Counseling } & .75 & .81 & .87 & .84 & .72 & .74 & .88 & .68 & -- & \\ \text { 10. Friendship } & .74 & .77 & .76 & .76 & .66 & .71 & .85 & .76 & .84 & --\end{array}$

Workplace Outcomes

\begin{tabular}{|c|c|c|c|c|c|c|c|c|c|c|c|c|}
\hline 11. Job Satisfaction & .89 & .70 & .67 & .67 & .54 & .68 & .69 & .66 & .67 & .67 & -- & \\
\hline 12. Comm Satisfaction '? & .71 & .73 & .69 & .71 & .58 & .68 & .76 & .76 & .73 & .80 & .73 & -- \\
\hline 13. Org Commitment & .91 & .70 & .69 & .69 & .57 & .69 & .72 & .65 & .68 & .66 & .88 & .75 \\
\hline
\end{tabular}

Note. All correlations are significant at the $p<.01$ level. Identification $=$ organizational identification. Exposure $=$ exposure and visibility. Assignments $=$ challenging assignments. Acceptance $=$ acceptance and confirmation . Comm satisfaction $=$ communication satisfaction . Org commitment $=$ organizational commitment . 


\section{Primary Analyses}

\section{Preliminary Analyses for Hypotheses One, Two, and Three}

To test hypotheses one, two, and three, a series of independent samples $t$-tests was conducted to determine if participants' reports of their organizational identification, their perceptions of their superiors' use of the five career development and the four psychosocial mentoring functions, and their reports of job satisfaction, communication satisfaction, and organizational commitment fluctuated based on workplace characteristics (i.e., their length of time working for their organization, length of time working in their current position, length of time working with their current supervisor, telecommuter status, and country in which their organization is located).

Length of time working for their organization. An independent samples $t$-test was conducted between individuals who worked for their organization for one year or less $(n=16)$ and individuals who worked for their organization for over a year $(n=284)$. Table 5 reports these results. No significant differences emerged between those individuals who worked for their organization for one year or less and those individuals who worked for their organization for over a year on organizational identification, the five career development and the four psychosocial mentoring functions, and job satisfaction, communication satisfaction, and organizational commitment.

Length of time working in their current position. An independent samples $t$ test was conducted between individuals who worked in their current position for one year or less $(n=30)$ and individuals who worked for their organization for over a year $(n=$ 270). Table 6 reports these results. No significant differences emerged between those individuals who worked in their current position for one year or less and those individuals 
Table 5

Length of Time Working for Their Organization

\begin{tabular}{|c|c|c|c|c|c|c|c|}
\hline \multirow[b]{2}{*}{ Variable } & \multicolumn{2}{|c|}{$\begin{array}{c}1 \text { Year or } \\
\text { Less }^{\mathrm{a}}\end{array}$} & \multicolumn{2}{|c|}{$>1$ Year $^{\mathrm{b}}$} & \multirow[b]{2}{*}{$d f$} & \multirow[b]{2}{*}{$t$} & \multirow[b]{2}{*}{$p$} \\
\hline & $M$ & $S D$ & $M$ & $S D$ & & & \\
\hline Identification & 5.01 & 1.86 & 5.13 & 1.47 & 292 & -.296 & .767 \\
\hline \multicolumn{8}{|c|}{ Career Development Mentoring Functions } \\
\hline Sponsorship & 4.65 & 1.72 & 4.88 & 1.40 & 297 & -.654 & .513 \\
\hline Exposure & 4.87 & 2.00 & 4.92 & 1.45 & 292 & -.135 & .892 \\
\hline Coaching & 4.73 & 1.85 & 5.00 & 1.44 & 296 & -.724 & .470 \\
\hline Protection & 4.13 & 1.51 & 4.52 & 1.39 & 298 & -1.095 & .274 \\
\hline Assignments & 5.02 & 1.81 & 5.30 & 1.35 & 294 & -.785 & .433 \\
\hline \multicolumn{8}{|c|}{ Psychosocial Mentoring Functions } \\
\hline Role Modeling & 4.88 & 2.05 & 4.81 & 1.61 & 296 & .145 & .885 \\
\hline Acceptance & 5.24 & 1.99 & 5.44 & 1.17 & 295 & -.610 & .542 \\
\hline Counseling & 4.69 & 2.02 & 4.89 & 1.55 & 297 & -.507 & 613 \\
\hline Friendship & 5.23 & 2.00 & 5.17 & 1.43 & 297 & .149 & .882 \\
\hline \multicolumn{8}{|l|}{ Workplace Outcomes } \\
\hline Job Satisfaction & 5.35 & 1.73 & 5.40 & 1.31 & 293 & -.153 & .878 \\
\hline Comm Satisfaction & 5.00 & 1.42 & 5.05 & 1.04 & 284 & -.182 & .856 \\
\hline Org Commitment & 4.79 & 1.52 & 4.81 & 1.22 & 288 & -.067 & .946 \\
\hline
\end{tabular}

Note. ${ }^{\mathrm{a}}=16 .{ }^{\mathrm{b}}=284$. Identification $=$ organizational identification. Exposure $=$ exposure and visibility. Assignments $=$ challenging assignments. Acceptance $=$ acceptance and confirmation. Comm satisfaction $=$ communication satisfaction. Org commitment $=$ organizational commitment. 
Table 6

Length of Time Working in Their Current Position

\begin{tabular}{|c|c|c|c|c|c|c|c|}
\hline \multirow[b]{2}{*}{ Variable } & \multicolumn{2}{|c|}{$\begin{array}{c}1 \text { Year or } \\
\text { Less }^{\mathrm{a}}\end{array}$} & \multicolumn{2}{|c|}{$>1$ Year $^{\mathrm{b}}$} & \multirow[b]{2}{*}{$d f$} & \multirow[b]{2}{*}{$t$} & \multirow[b]{2}{*}{$p$} \\
\hline & $M$ & $S D$ & $M$ & $S D$ & & & \\
\hline Identification & 4.91 & 1.57 & 5.15 & 1.48 & 292 & -.827 & .409 \\
\hline \multicolumn{8}{|c|}{ Career Development Mentoring Functions } \\
\hline Sponsorship & 4.70 & 1.42 & 4.89 & 1.42 & 297 & -.699 & .485 \\
\hline Exposure & 5.07 & 1.67 & 4.90 & 1.46 & 292 & .580 & .562 \\
\hline Coaching & 4.90 & 1.52 & 5.00 & 1.46 & 296 & -.345 & .731 \\
\hline Protection & 4.21 & 1.31 & 4.53 & 1.41 & 298 & -1.183 & .238 \\
\hline Assignments & 5.17 & 1.43 & 5.30 & 1.37 & 294 & -.491 & .624 \\
\hline \multicolumn{8}{|c|}{ Psychosocial Mentoring Functions } \\
\hline Role Modeling & 4.89 & 1.72 & 4.81 & 1.62 & 296 & .252 & .801 \\
\hline Acceptance & 5.24 & 1.56 & 5.45 & 1.18 & 295 & -.885 & .377 \\
\hline Counseling & 4.81 & 1.67 & 4.89 & 1.57 & 297 & -.259 & .796 \\
\hline Friendship & 5.18 & 1.61 & 5.18 & 1.45 & 297 & .006 & .995 \\
\hline \multicolumn{8}{|l|}{ Workplace Outcomes } \\
\hline Job Satisfaction & 5.22 & 1.45 & 5.42 & 1.32 & 293 & -.801 & .424 \\
\hline Comm Satisfaction & 4.88 & 1.17 & 5.06 & 1.05 & 284 & -.884 & .377 \\
\hline Org Commitment & 4.66 & 1.37 & 4.83 & 1.23 & 288 & -.719 & .473 \\
\hline
\end{tabular}

Note ${ }^{\mathrm{a}}=30 .{ }^{\mathrm{b}}=270$. Identification $=$ organizational identification. Exposure $=$ exposure and visibility. Assignments $=$ challenging assignments. Acceptance $=$ acceptance and confirmation . Comm satisfaction $=$ communication satisfaction. Org commitment $=$ organizational commitment. 
who worked in their current position for over a year on organizational identification, the five career development and the four psychosocial mentoring functions, and job satisfaction, communication satisfaction, and organizational commitment.

Length of time working with their current supervisor. An independent samples $t$-test was conducted between individuals who worked with their current supervisor for one year or less $(n=44)$ and individuals who worked with their current supervisor for over a year $(n=256)$. Table 7 reports these results. Significant differences emerged between those individuals who worked with their current supervisor for one year or less and those individuals who worked with their current supervisor for over a year on organizational identification, two of the five career development functions, and job satisfaction, communication satisfaction, and organizational commitment. Those individuals who worked with their current supervisor for one year or less reported experiencing less organizational identification, $t(292)=-2.995, p=.003$, Cohen's $d=$ 0.468; the sponsorship career development function, $t(297)=-2.007, p=.046$, Cohen's $d$ $=0.317$; the protection career development mentoring function, $t(298)=-2.980, p=.003$, Cohen's $d=0.491$; job satisfaction, $t(293)=-2.768, p=.006$, Cohen's $d=0.420$; communication satisfaction, $t(284)=-2.178, p=.030$, Cohen's $d=0.352$; and organizational commitment, $t(288)=-2.532, p=.012$, Cohen's $d=0.388$, than those individuals who worked with their current supervisor for over a year.

Telecommuter status. An independent samples $t$-test was conducted between individuals who did not telecommute to their workplace $(n=205)$ and individuals who did telecommute to their workplace $(n=94)$. Table 8 reports these results. Significant differences emerged between those individuals who did not telecommute to their 
Table 7

Length of Time Working with Their Current Supervisor

\begin{tabular}{|c|c|c|c|c|c|c|c|}
\hline \multirow[b]{2}{*}{ Variable } & \multicolumn{2}{|c|}{$\begin{array}{c}1 \text { Year or } \\
\text { Less }^{\mathrm{a}}\end{array}$} & \multicolumn{2}{|c|}{$>1$ Year $^{\mathrm{b}}$} & \multirow[b]{2}{*}{$d f$} & \multirow[b]{2}{*}{$t$} & \multirow[b]{2}{*}{$p$} \\
\hline & $M$ & $S D$ & $M$ & $S D$ & & & \\
\hline Identification & 4.49 & 1.73 & 5.23 & 1.42 & 292 & -2.995 & .003 \\
\hline \multicolumn{8}{|c|}{ Career Development Mentoring Functions } \\
\hline Sponsorship & 4.48 & 1.50 & 4.94 & 1.40 & 297 & -2.007 & .046 \\
\hline Exposure & 4.64 & 1.75 & 4.96 & 1.43 & 292 & -1.313 & .190 \\
\hline Coaching & 4.64 & 1.49 & 5.05 & 1.46 & 296 & -1.726 & .085 \\
\hline Protection & 3.92 & 1.39 & 4.60 & 1.38 & 298 & -2.980 & .003 \\
\hline Assignments & 5.02 & 1.47 & 5.33 & 1.36 & 294 & -1.364 & .173 \\
\hline \multicolumn{8}{|c|}{ Psychosocial Mentoring Functions } \\
\hline Role Modeling & 4.45 & 1.84 & 4.88 & 1.58 & 296 & -1.607 & .109 \\
\hline Acceptance & 5.10 & 1.48 & 5.49 & 1.17 & 295 & -1.938 & .054 \\
\hline Counseling & 4.65 & 1.65 & 4.92 & 1.56 & 297 & -1.038 & .300 \\
\hline Friendship & 4.89 & 1.65 & 5.23 & 1.42 & 297 & -1.428 & .154 \\
\hline \multicolumn{8}{|l|}{ Workplace Outcomes } \\
\hline Job Satisfaction & 4.89 & 1.57 & 5.49 & 1.27 & 293 & -2.768 & .006 \\
\hline Comm Satisfaction & 4.72 & 1.12 & 5.10 & 1.04 & 284 & -2.178 & .030 \\
\hline Org Commitment & 4.38 & 1.43 & 4.89 & 1.19 & 288 & -2.532 & .012 \\
\hline
\end{tabular}

Note ${ }^{\mathrm{a}}=44 .{ }^{\mathrm{b}}=256$. Identification $=$ organizational identification. Exposure $=$ exposure and visibility. Assignments $=$ challenging assignments. Acceptance $=$ acceptance and confirmation . Comm satisfaction $=$ communication satisfaction. Org commitment $=$ organizational commitment. 
Table 8

Telecommuter Status

\begin{tabular}{|c|c|c|c|c|c|c|c|}
\hline \multirow[b]{2}{*}{ Variable } & \multicolumn{2}{|c|}{$\begin{array}{c}\text { Don't } \\
\text { Telecommute }^{\mathrm{a}}\end{array}$} & \multicolumn{2}{|c|}{ Telecommute $^{\mathrm{b}}$} & \multirow[b]{2}{*}{$d f$} & \multirow[b]{2}{*}{$t$} & \multirow[b]{2}{*}{$p$} \\
\hline & $M$ & $S D$ & $M$ & $S D$ & & & \\
\hline Identification & 4.98 & 1.57 & 5.45 & 1.23 & 291 & -2.484 & .014 \\
\hline \multicolumn{8}{|c|}{ Career Development Mentoring Functions } \\
\hline Sponsorship & 4.76 & 1.49 & 5.13 & 1.23 & 296 & -2.113 & .035 \\
\hline Exposure & 4.69 & 1.54 & 5.39 & 1.25 & 291 & -3.837 & $<.001$ \\
\hline Coaching & 4.85 & 1.56 & 5.30 & 1.18 & 295 & -2.456 & .015 \\
\hline Protection & 4.34 & 1.43 & 4.84 & 1.29 & 297 & -2.882 & .004 \\
\hline Assignments & 5.16 & 1.48 & 5.57 & 1.07 & 293 & -2.403 & .017 \\
\hline \multicolumn{8}{|c|}{ Psychosocial Mentoring Functions } \\
\hline Role Modeling & 4.67 & 1.73 & 5.17 & 1.33 & 295 & -2.493 & .013 \\
\hline Acceptance & 5.44 & 1.27 & 5.43 & 1.11 & 294 & 0.041 & .967 \\
\hline Counseling & 4.71 & 1.68 & 5.26 & 1.25 & 296 & -2.847 & .005 \\
\hline Friendship & 5.06 & 1.58 & 5.44 & 1.14 & 296 & -2.058 & .040 \\
\hline \multicolumn{8}{|l|}{ Workplace Outcomes } \\
\hline Job Satisfaction & 5.36 & 1.43 & 5.49 & 1.07 & 292 & -0.776 & .438 \\
\hline Comm Satisfaction & 5.11 & 1.13 & 4.92 & 0.85 & 283 & 1.455 & .147 \\
\hline Org Commitment & 4.80 & 1.34 & 4.84 & 0.99 & 288 & -0.299 & .765 \\
\hline
\end{tabular}

Note ${ }^{\mathrm{a}}=205 .{ }^{\mathrm{b}}=94$. Identification $=$ organizational identification. Exposure $=$ exposure and visibility. Assignments $=$ challenging assignments. Acceptance $=$ acceptance and confirmation. Comm satisfaction $=$ communication satisfaction. Org commitment $=$ organizational commitment. 
workplace and those individuals who did telecommute to their workplace on organizational identification, the five career development functions, and three of the four psychosocial functions. Those individuals who did not telecommute to their workplace reported experiencing less organizational identification, $t(291)=-2.484, p=.014$, Cohen's $d=0.333$; the sponsorship career development mentoring function, $t(296)=$ $-2.113, p=.035$, Cohen's $d=0.271$; the exposure and visibility career development mentoring function, $t(291)=-3.837, p<.001$, Cohen's $d=0.499$; the coaching career development mentoring function, $t(295)=-2.456, p=.015$, Cohen's $d=0.325$; the protection career development mentoring function, $t(297)=-2.882, p=.004$, Cohen's $d=$ 0.367 ; the challenging assignments career development mentoring function, $t(293)=$ $-2.403, p=.017$, Cohen's $d=0.317$; the role modeling psychosocial mentoring function, $t(295)=-2.493, p=.013$, Cohen's $d=0.324$; the counseling psychosocial mentoring function, $t(296)=-2.847, p=.005$, Cohen's $d=0.371$; and the friendship psychosocial mentoring function, $t(296)=-2.058, p=.040$, Cohen's $d=0.276$, than those individuals who did telecommute to their workplace.

Country in which their organization is located. An independent samples $t$-test was conducted between individuals whose organization was located in the United States $(n=212)$ and individuals whose organization was located outside of the United States ( $n$ =88). Table 9 reports these results. Significant differences emerged between those individuals whose organization was located in the United States and those individuals whose organization was located outside of the United States on organizational identification and four of the five career development functions. Those individuals whose organization was located in the United States reported experiencing less organizational 
Table 9

Country in which Their Organization is Located

\begin{tabular}{|c|c|c|c|c|c|c|c|}
\hline \multirow[b]{2}{*}{ Variable } & \multicolumn{2}{|c|}{$\begin{array}{l}\text { United States } \\
\text { employees }^{\mathrm{a}}\end{array}$} & \multicolumn{2}{|c|}{$\begin{array}{c}\text { non-United States } \\
\text { employees }^{\mathrm{b}}\end{array}$} & \multirow[b]{2}{*}{$d f$} & \multirow[b]{2}{*}{$t$} & \multirow[b]{2}{*}{$p$} \\
\hline & $M$ & $S D$ & $M$ & $S D$ & & & \\
\hline Identification & 4.98 & 1.63 & 5.47 & 1.00 & 292 & -2.632 & .009 \\
\hline \multicolumn{8}{|c|}{ Career Development Mentoring Functions } \\
\hline Sponsorship & 4.79 & 1.52 & 5.06 & 1.11 & 297 & -1.519 & .130 \\
\hline Exposure & 4.72 & 1.58 & 5.37 & 1.09 & 292 & -3.469 & .001 \\
\hline Coaching & 4.88 & 1.59 & 5.25 & 1.07 & 296 & -1.979 & .049 \\
\hline Protection & 4.37 & 1.49 & 4.80 & 1.10 & 298 & -2.391 & .017 \\
\hline Assignments & 5.15 & 1.52 & 5.60 & 0.90 & 294 & -2.585 & .010 \\
\hline \multicolumn{8}{|c|}{ Psychosocial Mentoring Functions } \\
\hline Role Modeling & 4.74 & 1.72 & 5.01 & 1.36 & 296 & -1.331 & .184 \\
\hline Acceptance & 5.47 & 1.29 & 5.33 & 1.03 & 295 & 0.904 & .367 \\
\hline Counseling & 4.79 & 1.66 & 5.11 & 1.35 & 297 & -1.594 & .112 \\
\hline Friendship & 5.14 & 1.55 & 5.25 & 1.23 & 297 & -0.593 & .553 \\
\hline \multicolumn{8}{|l|}{ Workplace Outcomes } \\
\hline Job Satisfaction & 5.31 & 1.47 & 5.62 & 0.85 & 293 & -1.771 & .078 \\
\hline Comm Satisfaction & 5.10 & 1.19 & 4.91 & 0.61 & 284 & 1.424 & .156 \\
\hline Org Commitment & 4.81 & 1.39 & 4.82 & 0.77 & 288 & -0.040 & .968 \\
\hline
\end{tabular}

Note ${ }^{\mathrm{a}}=212 .{ }^{\mathrm{b}}=88$. Identification $=$ organizational identification. Exposure $=$ exposure and visibility. Assignments $=$ challenging assignments. Acceptance $=$ acceptance and confirmation . Comm satisfaction $=$ communication satisfaction. Org commitment $=$ organizational commitment. 
identification, $t(292)=-2.632, p=.009$, Cohen's $d=0.362$; the exposure and visibility career development mentoring function, $t(292)=-3.469, p=.001$, Cohen's $d=0.479$; the coaching career development function, $t(296)=-1.979, p=.049$, Cohen's $d=0.273$; the protection career development function, $t(298)=-2.391, p=.017$, Cohen's $d=0.328$; and the challenging assignments career development mentoring function, $t(294)=-2.585$, $p=.010$, Cohen's $d=0.360$, than those individuals whose organization was located outside of the United States.

\section{Hypothesis One}

The first hypothesis predicted that subordinates who perceive their superiors as enacting (a) the five career development mentoring functions (i.e., sponsorship, exposure and visibility, coaching, protection, and challenging assignments) and (b) the four psychosocial mentoring functions (i.e., role modeling, acceptance and confirmation, counseling, and friendship) would more highly identify with their organization.

Controlling for length of time working with their current supervisor, telecommuter status, and country in which their organization is located, hypothesis one was supported. Table 10 reports these results.

\section{Hypothesis Two}

The second hypothesis predicted that subordinate organizational identification would be associated positively with (a) job satisfaction, (b) communication satisfaction with superiors, and (c) organizational commitment. Controlling for length of time working with their current supervisor, telecommuter status, and country in which their organization is located, hypothesis two was supported. Table 11 reports these results. 
Table 10

Hypothesis One Partial Correlation Matrix

$\begin{array}{lllllllllll} & \text { Variable } & 1 & 2 & 3 & 4 & 5 & 6 & 7 & 8 & 9\end{array}$

1. Identification --

Career Development Mentoring Functions

2. Sponsorship $\quad .76 \quad--$

3. Exposure $\quad .76 \quad .83 \quad--$

$\begin{array}{lllll}\text { 4. Coaching } \quad .72 & .81 & .81 & --\end{array}$

$\begin{array}{llll}\text { 5. Protection } \quad .62 & .72 & .75 & .68\end{array}$

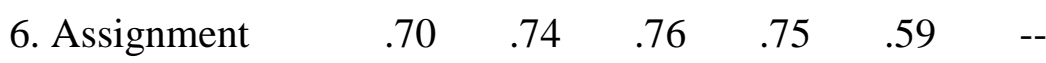

Psychosocial Mentoring Functions

$\begin{array}{llllllll}\text { 7. Role Modeling } & .76 & .81 & .82 & .80 & .71 & .72 & --\end{array}$

$\begin{array}{lllllllll}\text { 8. Acceptance } & .73 & .71 & .70 & .62 & .57 & .68 & .72 & --\end{array}$

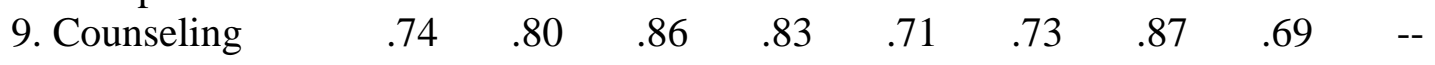

$\begin{array}{llllllllll}\text { 10. Friendship } & .73 & .76 & .77 & .74 & .65 & .70 & .84 & .77 & .84\end{array}$

Note. $d f=270$. All correlations are significant at the $p<.001$ level. Identification $=$ organizational identification. Exposure $=$ exposure and visibility. Assignments $=$ challenging assignments. Acceptance $=$ acceptance and confirmation. 
Table 11

Hypothesis Two Partial Correlation Matrix

Variable

2

3

1. Organizational Identification

Workplace Outcomes

2. Job Satisfaction

.89

3. Communication Satisfaction

.74

4. Organizational Commitment

.92

74

Note. $d f=262$. All correlations are significant at the $p<.001$ level. 


\section{Hypothesis Three}

The third hypothesis predicted that subordinate perceptions of superiors' enactment of (a) the five career development mentoring functions (i.e., sponsorship, exposure and visibility, coaching, protection, and challenging assignments) and (b) the four psychosocial mentoring functions (i.e., role modeling, acceptance and confirmation, counseling, and friendship) would be associated positively with subordinates' (a) job satisfaction, (b) communication satisfaction with superiors, and (c) organizational commitment. Controlling for length of time working with their current supervisor, telecommuter status, and country in which their organization is located, hypothesis three was supported. Table 12 reports these results.

\section{Hypothesis Four}

The fourth hypothesis predicted that the effect of subordinate perceptions of superiors' enactment of (a) the five career development mentoring functions (i.e., sponsorship, exposure and visibility, coaching, protection, and challenging assignments) and (b) the four psychosocial mentoring functions (i.e., role modeling, acceptance and confirmation, counseling, and friendship) on subordinate (a) job satisfaction, (b) communication satisfaction with their superior, and (c) organizational commitment would be affected indirectly by subordinates' organizational identification. Controlling for length of time working with their current supervisor, telecommuter status, and country in which their organization is located, three series of simple mediation analyses were conducted to analyze hypothesis four. The first series of simple mediation analyses situated job satisfaction as the outcome variable; the second series of simple mediation analyses situated communication satisfaction as the outcome variable; and the third series 
Table 12

Hypothesis Three Partial Correlation Matrix

$\begin{array}{llllllllllllll}\text { Variable } & 1 & 2 & 3 & 4 & 5 & 6 & 7 & 8 & 9 & 10 & 11\end{array}$

Career Development Mentoring Functions

$\begin{array}{lllllll}\text { 1. Sponsorship } & -- & & & & \\ \text { 2. Exposure } & .83 & -- & & & \\ \text { 3. Coaching } & .82 & .82 & -- & & \\ \text { 4. Protection } & .73 & .77 & .70 & -- & \\ \text { 5. Assignment } & .74 & .76 & .75 & .61 & --\end{array}$

Psychosocial Mentoring Functions

\begin{tabular}{|c|c|c|c|c|c|c|c|c|c|c|c|}
\hline 6. Role Modeling & .80 & .82 & .80 & .73 & .71 & -- & & & & & \\
\hline 7. Acceptance & .72 & .70 & .63 & .59 & .67 & .72 & -- & & & & \\
\hline 8. Counseling & .80 & .86 & .85 & .73 & .73 & .87 & .70 & -- & & & \\
\hline 9. Friendship & .76 & .75 & .75 & .67 & .69 & .83 & .77 & .84 & -- & & \\
\hline \multicolumn{12}{|l|}{ Workplace Outcomes } \\
\hline 10. Job Satisfaction & .70 & .66 & .66 & .54 & .66 & .68 & .67 & .66 & .65 & -- & \\
\hline 11. Comm Satisfaction & .76 & .74 & .73 & .62 & .70 & .79 & .77 & .77 & .82 & .74 & -- \\
\hline 12. Org Commitment & .70 & .70 & .68 & .56 & .69 & .71 & .65 & .67 & .64 & .88 & .75 \\
\hline
\end{tabular}

Note. $d f=251$. All correlations are significant at the $p<.001$ level. Identification $=$ organizational identification. Exposure $=$ exposure and visibility. Assignments $=$ challenging assignments. Acceptance $=$ acceptance and confirmation. Comm satisfaction $=$ communication satisfaction . Org commitment $=$ organizational commitment. 
of simple mediation analyses situated organizational commitment as the outcome variable. Hypothesis four was supported.

Job satisfaction. The first series of simple mediation model analyses tested the indirect effect of the five career development and the four psychosocial mentoring functions on job satisfaction through organizational identification. Nine simple mediation model analyses were conducted. The first mediation model analysis tested the indirect effect of the sponsorship career development mentoring function on job satisfaction through organizational identification, controlling for length of time working with their current supervisor, telecommuter status, and country in which their organization is located. Table 13 displays the unstandardized path model coefficients $\left(a, b, c^{\prime}\right)$ and variance accounted for by the variables in the model. The $95 \%$ percentile bootstrap confidence interval provided evidence of an indirect effect as it was entirely above zero $[.521, .731]$, with an indirect effect of $a b=.624$ and a completely standardized indirect effect of $a b_{c s}=.667,95 \%$ CI $[.579, .757]$. The direct effect of the sponsorship career development mentoring function on job satisfaction was not significant $\left(c^{\prime}=.022, p=\right.$ .557) and the total effect of the sponsorship career development mentoring function on job satisfaction was .646 $(p<.001)$.

The second mediation model analysis tested the indirect effect of the exposure and visibility career development mentoring function on job satisfaction through organizational identification, controlling for length of time working with their current supervisor, telecommuter status, and country in which their organization is located. Table 14 displays the unstandardized path model coefficients $\left(a, b, c^{\prime}\right)$ and variance accounted for by the variables in the model. The $95 \%$ percentile bootstrap confidence interval 
Table 13

Unstandardized Path Coefficients for Sponsorship and Job Satisfaction Model

\begin{tabular}{|c|c|c|c|c|c|c|}
\hline Models ( $X=$ Sponsorship) & Coeff & SE & $t$ & $p$ & LLCI & ULCI \\
\hline \multicolumn{7}{|c|}{$M=$ Identification } \\
\hline \multicolumn{7}{|c|}{$F(4,282)=107.092, p<.001, R^{2}=.603$, Adjusted $R^{2}=.597$} \\
\hline Constant & .892 & .231 & 3.855 & $<.001$ & .436 & 1.347 \\
\hline Sponsorship $(a)$ & .788 & .040 & 19.707 & $<.001$ & .709 & .866 \\
\hline Time working with supervisor & .355 & .160 & 2.216 & .027 & .040 & .671 \\
\hline Telecommuter status & .068 & .137 & 0.499 & 618 & -.201 & .337 \\
\hline Country & .210 & .139 & 1.510 & .132 & -.064 & .485 \\
\hline \multicolumn{7}{|c|}{$\begin{aligned} Y & =\text { Job Satisfaction } \\
F(5,281) & =237.240, p<.001, R^{2}=.808, \text { Adjusted } R^{2}=.805\end{aligned}$} \\
\hline Constant & 1.361 & .147 & 9.261 & $<.001$ & 1.072 & 1.651 \\
\hline Identification $(b)$ & .792 & .037 & 21.469 & $<.001$ & .719 & .864 \\
\hline Sponsorship $\left(c^{\prime}\right)$ & .022 & .038 & 0.587 & .557 & -.053 & .098 \\
\hline Time working with supervisor & -.048 & .100 & -0.483 & .630 & -.245 & .149 \\
\hline Telecommuter status & -.289 & .085 & -3.420 & .001 & -.456 & -.123 \\
\hline Country & .053 & .087 & 0.614 & .540 & -.117 & .224 \\
\hline
\end{tabular}

Note . Identification $=$ organizational identification. Time working with supervisor $=$ length of time working with supervisor. 
Table 14

Unstandardized Path Coefficients for Exposure and Visibility and Job Satisfaction Model

\begin{tabular}{|c|c|c|c|c|c|c|}
\hline Models $(X=$ Exposure $)$ & Coeff & SE & $t$ & $p$ & LLCI & ULCI \\
\hline \multicolumn{7}{|c|}{$M=$ Identification } \\
\hline \multicolumn{7}{|c|}{$F(4,277)=105.394, p<.001, R^{2}=.603$, Adjusted $R^{2}=.597$} \\
\hline Constant & .968 & .230 & 4.199 & $<.001$ & .514 & 1.421 \\
\hline Exposure $(a)$ & .761 & .039 & 19.564 & $<.001$ & 684 & .837 \\
\hline Time working with supervisor & .530 & .160 & 3.313 & .001 & .215 & .845 \\
\hline Telecommuter status & -.105 & .137 & -0.765 & .445 & -.374 & .165 \\
\hline Country & -.011 & .139 & -0.082 & .935 & -.286 & .263 \\
\hline \multicolumn{7}{|c|}{$\begin{array}{c}Y=\text { Job Satisfaction } \\
F(5,276)=226.321, p<.001, R^{2}=.804, \text { Adjusted } R^{2}=.800\end{array}$} \\
\hline Constant & 1.432 & .149 & 9.637 & $<.001$ & 1.139 & 1.725 \\
\hline Identification $(b)$ & .815 & .038 & 21.703 & $<.001$ & .741 & .889 \\
\hline Exposure $\left(c^{\prime}\right)$ & -.015 & .038 & -0.406 & .685 & -.089 & .059 \\
\hline Time working with supervisor & -.051 & .102 & -0.503 & .615 & -.252 & .149 \\
\hline Telecommuter status & -.286 & .086 & -3.345 & .001 & -.455 & -.118 \\
\hline Country & .051 & .087 & 0.591 & .555 & -.120 & .224 \\
\hline
\end{tabular}

Note. Identification $=$ organizational identification. Exposure $=$ exposure and visibility. Time working with supervisor $=$ length of time working with supervisor. 
provided evidence of an indirect effect as it was entirely above zero [.517, .726], with an indirect effect of $a b=.620$ and a completely standardized indirect effect of $a b_{c s}=.704$, $95 \%$ CI $[.606, .804]$. The direct effect of the exposure and visibility career development mentoring function on job satisfaction was not significant $\left(c^{\prime}=-.015, p=.685\right)$ and the total effect of the exposure and visibility career development mentoring function on job satisfaction was .605 $(p<.001)$.

The third mediation model analysis tested the indirect effect of the coaching career development mentoring function on job satisfaction through organizational identification, controlling for length of time working with their current supervisor, telecommuter status, and country in which their organization is located. Table 15 displays the unstandardized path model coefficients $\left(a, b, c^{\prime}\right)$ and variance accounted for by the variables in the model. The $95 \%$ percentile bootstrap confidence interval provided evidence of an indirect effect as it was entirely above zero [.485, .678], with an indirect effect of $a b=.581$ and a completely standardized indirect effect of $a b_{c s}=.644,95 \% \mathrm{CI}$ $[.559, .728]$. The direct effect of the coaching career development mentoring function on job satisfaction was not significant $\left(c^{\prime}=.012, p=.721\right)$ and the total effect of the coaching career development mentoring function on job satisfaction was .593 $(p<.001)$.

The fourth mediation model analysis tested the indirect effect of the protection career development mentoring function on job satisfaction through organizational identification, controlling for length of time working with their current supervisor, telecommuter status, and country in which their organization is located. Table 16 displays the unstandardized path model coefficients $\left(a, b, c^{\prime}\right)$ and variance accounted for by the variables in the model. The $95 \%$ percentile bootstrap confidence interval provided 
Table 15

Unstandardized Path Coefficients for Coaching and Job Satisfaction Model

\begin{tabular}{|c|c|c|c|c|c|c|}
\hline Models $(X=$ Coaching $)$ & Coeff & SE & $t$ & $p$ & LLCI & ULCI \\
\hline \multicolumn{7}{|c|}{$M=$ Identification } \\
\hline \multicolumn{7}{|c|}{$F(4,281)=87.695, p<.001, R^{2}=.555$, Adjusted $R^{2}=.549$} \\
\hline Constant & 1.064 & .245 & 4.349 & $<.001$ & .582 & 1.545 \\
\hline Coaching $(a)$ & .724 & .041 & 17.754 & $<.001$ & .647 & .808 \\
\hline Time working with supervisor & .418 & .170 & 2.461 & .014 & .084 & .752 \\
\hline Telecommuter status & .074 & .145 & 0.509 & .611 & -.211 & .359 \\
\hline Country & .141 & .148 & 0.955 & .340 & -.150 & .433 \\
\hline \multicolumn{7}{|c|}{$\begin{aligned} Y & =\text { Job Satisfaction } \\
F(5,280) & =235.769, p<.001, R^{2}=.808, \text { Adjusted } R^{2}=.805\end{aligned}$} \\
\hline Constant & 1.374 & .148 & 9.294 & $<.001$ & 1.083 & 1.665 \\
\hline Identification $(b)$ & .798 & .035 & 22.867 & $<.001$ & .730 & .867 \\
\hline Coaching $\left(c^{\prime}\right)$ & .012 & .035 & 0.358 & .721 & -.056 & .081 \\
\hline Time working with supervisor & -.052 & .100 & -0.515 & .607 & -.249 & .146 \\
\hline Telecommuter status & -.286 & .085 & -3.369 & .001 & -.453 & -.119 \\
\hline Country & .054 & .087 & 0.623 & .534 & -.117 & .225 \\
\hline
\end{tabular}

Note. Identification $=$ organizational identification. Time working with supervisor $=$ length of time working with supervisor. 
Table 16

Unstandardized Path Coefficients for Protection and Job Satisfaction Model

\begin{tabular}{|c|c|c|c|c|c|c|}
\hline Models ( $X=$ Protection $)$ & Coeff & SE & $t$ & $p$ & LLCI & ULCI \\
\hline \multicolumn{7}{|c|}{$M=$ Identification } \\
\hline \multicolumn{7}{|c|}{$F(4,283)=52.158, p<001, R^{2}=.424$, Adjusted $R^{2}=.416$} \\
\hline Constant & 1.828 & .261 & 7.006 & $<.001$ & 1.314 & 2.341 \\
\hline Protection $(a)$ & .660 & .049 & 13.458 & $<.001$ & .564 & .757 \\
\hline Time working with supervisor & .310 & .194 & 1.599 & .111 & -.072 & .691 \\
\hline Telecommuter status & .031 & .165 & 0.189 & .850 & -.293 & .356 \\
\hline Country & .168 & .168 & 1.001 & .318 & -.162 & .498 \\
\hline \multicolumn{7}{|c|}{$\begin{aligned} Y & =\text { Job Satisfaction } \\
F(5,282) & =240.572, p<.001, R^{2}=.810, \text { Adjusted } R^{2}=.807\end{aligned}$} \\
\hline Constant & 1.456 & .145 & 10.066 & $<.001$ & 1.172 & 1.741 \\
\hline Identification $(b)$ & .839 & .030 & 27.577 & $<.001$ & .779 & .899 \\
\hline Protection $\left(c^{\prime}\right)$ & -.053 & .032 & -1.652 & .100 & -.117 & .010 \\
\hline Time working with supervisor & -.042 & .100 & -0.424 & .672 & -.238 & .154 \\
\hline Telecommuter status & -.275 & .084 & -3.257 & .001 & -.441 & -.109 \\
\hline Country & .054 & .086 & 0.628 & .531 & -.115 & .223 \\
\hline
\end{tabular}

Note . Identification $=$ organizational identification. Time working with supervisor $=$ length of time working with supervisor. 
evidence of an indirect effect as it was entirely above zero [.453, .655], with an indirect effect of $a b=.554$ and a completely standardized indirect effect of $a b_{c s}=.589,95 \% \mathrm{CI}$ $[.493, .680]$. The direct effect of the protection career development mentoring function on job satisfaction was not significant $\left(c^{\prime}=-.053, p=.100\right)$ and the total effect of the protection career development mentoring function on job satisfaction was .501 $(p<.001)$.

The fifth mediation model analysis tested the indirect effect of the challenging assignments career development mentoring function on job satisfaction through organizational identification, controlling for length of time working with their current supervisor, telecommuter status, and country in which their organization is located. Table 17 displays the unstandardized path model coefficients $\left(a, b, c^{\prime}\right)$ and variance accounted for by the variables in the model. The $95 \%$ percentile bootstrap confidence interval provided evidence of an indirect effect as it was entirely above zero [.473, .687], with an indirect effect of $a b=.579$ and a completely standardized indirect effect of $a b_{c s}=.605$, 95\% CI $[.514, .694]$. The direct effect of the challenging assignments career development mentoring function on job satisfaction was not significant $\left(c^{\prime}=.064, p=.080\right)$ and the total effect of the challenging assignments career development mentoring function on job satisfaction was .643 $(p<.001)$.

The sixth mediation model analysis tested the indirect effect of the role modeling psychosocial mentoring function on job satisfaction through organizational identification, controlling for length of time working with their current supervisor, telecommuter status, and country in which their organization is located. Table 18 displays the unstandardized path model coefficients $\left(a, b, c^{\prime}\right)$ and variance accounted for by the variables in the model. The $95 \%$ percentile bootstrap confidence interval provided evidence of an indirect 
Table 17

Unstandardized Path Coefficients for Challenging Assignments and Job Satisfaction Model

Models $(X=$ Assignments $) \quad$ Coeff $\quad$ SE $\quad t \quad p \quad$ LLCI ULCI

$M=$ Identification

$F(4,279)=81.196, p<.001, R^{2}=.538$, Adjusted $R^{2}=.531$

$\begin{array}{lllllll}\text { Constant } & .600 & .274 & 2.193 & .029 & .061 & 1.138\end{array}$

$\begin{array}{llllllll}\text { Assignments }(a) & .762 & .045 & 17.029 & <.001 & .674 & .850\end{array}$

$\begin{array}{llllllll}\text { Time working with supervisor } & .532 & .172 & 3.098 & .002 & .194 & .869\end{array}$

$\begin{array}{lllllll}\text { Telecommuter status } & .106 & .147 & 0.719 & .473 & -.183 & .395\end{array}$

$\begin{array}{lllllll}\text { Country } & .034 & .151 & 0.223 & .824 & -.263 & .330\end{array}$

$Y=$ Job Satisfaction

$F(5,278)=232.731, p<.001, R^{2}=.807$, Adjusted $R^{2}=.804$

$\begin{array}{lllllll}\text { Constant } & 1.285 & .158 & 8.129 & <.001 & .974 & 1.597\end{array}$

$\begin{array}{lllllll}\text { Identification }(b) & .759 & .034 & 22.132 & <.001 & .692 & .827\end{array}$

$\begin{array}{lllllll}\text { Assignments }\left(c^{\prime}\right) & .064 & .037 & 1.755 & .080 & -.008 & .136\end{array}$

$\begin{array}{llllllll}\text { Time working with supervisor } & -.032 & .100 & -0.324 & .746 & -.229 & .164\end{array}$

$\begin{array}{lllllll}\text { Telecommuter status } & -.290 & .084 & -3.443 & .001 & -.456 & -.124\end{array}$

$\begin{array}{lllllll}\text { Country } & .042 & .086 & 0.483 & .630 & -.128 & .212\end{array}$

Note . Identification $=$ organizational identification. Assignments $=$ challenging assignments.

Time working with supervisor $=$ length of time working with supervisor. 
Table 18

Unstandardized Path Coefficients for Role Modeling and Job Satisfaction Model

\begin{tabular}{|c|c|c|c|c|c|c|}
\hline Models ( $X=$ Role Modeling) & Coeff & SE & $t$ & $p$ & LLCI & ULC \\
\hline \multicolumn{7}{|c|}{$M=$ Identification } \\
\hline Constant & 1.315 & .210 & 6.270 & $<.001$ & .902 & 1.728 \\
\hline Role Modeling $(a)$ & .696 & .034 & 20.405 & $<.001$ & .629 & .763 \\
\hline Time working with supervisor & .442 & .157 & 2.821 & .005 & .134 & .751 \\
\hline Telecommuter status & -.056 & .135 & -0.419 & .675 & -.321 & .208 \\
\hline Country & .298 & .137 & 2.182 & .030 & .029 & .567 \\
\hline \multicolumn{7}{|c|}{$\begin{array}{c}Y=\text { Job Satisfaction } \\
F(5,281)=237.519, p<.001, R^{2}=.809, \text { Adjusted } R^{2}=.806\end{array}$} \\
\hline Constant & 1.387 & .141 & 9.810 & $<.001$ & 1.108 & 1.665 \\
\hline Identification $(b)$ & .805 & .038 & 21.412 & $<.001$ & .731 & .879 \\
\hline Role Modeling $\left(c^{\prime}\right)$ & .003 & .034 & 0.099 & .921 & -.063 & .070 \\
\hline Time working with supervisor & -.053 & .100 & -0.515 & .600 & -.250 & .145 \\
\hline Telecommuter status & -.286 & .085 & -3.369 & .001 & -.453 & -.119 \\
\hline Country & .055 & .087 & 0.629 & .530 & -.116 & .226 \\
\hline
\end{tabular}

Note. Identification $=$ organizational identification. Time working with supervisor $=$ length of time working with supervisor. 
effect as it was entirely above zero $[.468, .656]$, with an indirect effect of $a b=.560$ and a completely standardized indirect effect of $a b_{c s}=.689,95 \%$ CI $[.599, .782]$. The direct effect of the role modeling psychosocial mentoring function on job satisfaction was not significant $\left(c^{\prime}=.003, p=.921\right)$ and the total effect of the role modeling psychosocial mentoring function on job satisfaction was .564 $(p<.001)$.

The seventh mediation model analysis tested the indirect effect of the acceptance and confirmation psychosocial mentoring function on job satisfaction through organizational identification, controlling for length of time working with their current supervisor, telecommuter status, and country in which their organization is located. Table 19 displays the unstandardized path model coefficients $\left(a, b, c^{\prime}\right)$ and variance accounted for by the variables in the model. The $95 \%$ percentile bootstrap confidence interval provided evidence of an indirect effect as it was entirely above zero [.595, .816], with an indirect effect of $a b=.701$ and a completely standardized indirect effect of $a b_{c s}=.633$, $95 \%$ CI $[.550, .720]$. The direct effect of the acceptance and confirmation psychosocial mentoring function on job satisfaction was not significant $\left(c^{\prime}=.023, p=.589\right)$ and the total effect of the acceptance and confirmation psychosocial career development mentoring function on job satisfaction was .724 $(p<.001)$.

The eighth mediation model analysis tested the indirect effect of the counseling psychosocial mentoring function on job satisfaction through organizational identification, controlling for length of time working with their current supervisor, telecommuter status, and country in which their organization is located. Table 20 displays the unstandardized path model coefficients $\left(a, b, c^{\prime}\right)$ and variance accounted for by the variables in the model. The $95 \%$ percentile bootstrap confidence interval provided evidence of an indirect 
Table 19

Unstandardized Path Coefficients for Acceptance and Confirmation and Job Satisfaction Model

Models $(X=$ Acceptance $)$
$M=$ Identification

$F(4,280)=87.180, p<.001, R^{2}=.555$, Adjusted $R^{2}=.549$

$\begin{array}{llllllll}\text { Constant } & -.248 & .306 & -0.813 & .417 & -.850 & .353\end{array}$

$\begin{array}{lllllll}\text { Acceptance }(a) & .880 & .050 & 17.646 & <.001 & .781 & .978\end{array}$

$\begin{array}{llllllll}\text { Time working with supervisor } & .396 & .174 & 2.284 & .023 & .055 & .738\end{array}$

$\begin{array}{lllllll}\text { Telecommuter status } & .273 & .144 & 1.889 & .060 & -.012 & .557\end{array}$

$\begin{array}{lllllll}\text { Country } & .463 & .148 & 3.133 & .002 & .172 & .755\end{array}$

\begin{tabular}{lrrrrrr}
\multicolumn{1}{c}{$Y=$ Job Satisfaction } \\
$F(5,279)=237.479, p<.001, R^{2}=.810$, Adjusted $R^{2}=.807$ \\
Constant & 1.319 & .179 & 7.383 & $<.001$ & .968 & 1.671 \\
Identification $(b)$ & .797 & .035 & 22.842 & $<.001$ & .728 & .866 \\
Acceptance $\left(c^{\prime}\right)$ & .023 & .042 & 0.542 & .589 & -.060 & .106 \\
Time working with supervisor & -.048 & .102 & -0.471 & .638 & -.249 & .153 \\
Telecommuter status & -.288 & .085 & -3.388 & .001 & -.455 & -.120 \\
Country & .056 & .088 & 0.638 & .524 & -.117 & .229
\end{tabular}

Note . Identification $=$ organizational identification. Acceptance $=$ acceptance and confirmation. Time working with supervisor $=$ length of time working with supervisor. 
Table 20

Unstandardized Path Coefficients for Counseling and Job Satisfaction Model

\begin{tabular}{|c|c|c|c|c|c|c|}
\hline Models ( $X=$ Counseling $)$ & Coeff & SE & $t$ & $p$ & LLCI & ULCI \\
\hline \multicolumn{7}{|c|}{$M=$ Identification } \\
\hline Constant & 1.310 & .227 & 5.759 & $<.001$ & .862 & 1.758 \\
\hline Counseling $(a)$ & .688 & .037 & 18.795 & $<.001$ & .616 & .760 \\
\hline Time working with supervisor & .489 & .164 & 2.973 & .003 & .165 & .813 \\
\hline Telecommuter status & -.052 & .140 & -0.368 & .713 & -.327 & .224 \\
\hline Country & .219 & .142 & 1.542 & .124 & -.061 & .499 \\
\hline \multicolumn{7}{|c|}{$\begin{array}{c}Y=\text { Job Satisfaction } \\
F(5,281)=231.830, p<.001, R^{2}=.805, \text { Adjusted } R^{2}=.802\end{array}$} \\
\hline Constant & 1.433 & .145 & 9.878 & $<.001$ & 1.147 & 1.718 \\
\hline Identification $(b)$ & .795 & .036 & 22.131 & $<.001$ & .724 & .866 \\
\hline Counseling $\left(c^{\prime}\right)$ & .009 & .033 & 0.284 & .777 & -.056 & .075 \\
\hline Time working with supervisor & -.071 & .101 & -0.708 & .480 & -.270 & .127 \\
\hline Telecommuter status & -.292 & .085 & -3.451 & .001 & -.458 & -.125 \\
\hline Country & .053 & .086 & 0.616 & .539 & -.117 & .223 \\
\hline
\end{tabular}

Note. Identification $=$ organizational identification. Time working with supervisor $=$ length of time working with supervisor. 
effect as it was entirely above zero [.454, .644], with an indirect effect of $a b=.547$ and a completely standardized indirect effect of $a b_{c s}=.662,95 \%$ CI $[.572, .758]$. The direct effect of the counseling psychosocial mentoring function on job satisfaction was not significant $\left(c^{\prime}=.009, p=.777\right)$ and the total effect of the counseling psychosocial mentoring function on job satisfaction was .556 $(p<.001)$.

The ninth mediation model analysis tested the indirect effect of the friendship psychosocial mentoring function on job satisfaction through organizational identification, controlling for length of time working with their current supervisor, telecommuter status, and country in which their organization is located. Table 21 displays the unstandardized path model coefficients $\left(a, b, c^{\prime}\right)$ and variance accounted for by the variables in the model. The $95 \%$ percentile bootstrap confidence interval provided evidence of an indirect effect as it was entirely above zero [.506, .703], with an indirect effect of $a b=.601$ and a completely standardized indirect effect of $a b_{c s}=.661,95 \%$ CI $[.569, .757]$. The direct effect of the friendship psychosocial mentoring function on job satisfaction was not significant $\left(c^{\prime}=.002, p=.957\right)$ and the total effect of the friendship psychosocial mentoring function on job satisfaction was .603 $(p<.001)$.

In sum, the results of this first series of simple mediation model analyses indicate that, controlling for length of time working with their current supervisor, telecommuter status, and country in which their organization is located, subordinates' reports of their supervisors' use of the five career development mentoring functions and the four psychosocial mentoring functions positively affects subordinates' job satisfaction indirectly through their experienced organizational identification. This was true for all five of the career development mentoring functions and for all four of the psychosocial 
Table 21

Unstandardized Path Coefficients for Friendship and Job Satisfaction Model

\begin{tabular}{|c|c|c|c|c|c|c|}
\hline Models ( $X=$ Friendship) & Coeff & $\mathrm{SE}$ & $t$ & $p$ & LLCI & ULCI \\
\hline \multicolumn{7}{|l|}{$M=$ Identification } \\
\hline \multicolumn{7}{|c|}{$F(4,283)=96.645, p<.001, R^{2}=.577$, Adjusted $R^{2}=.571$} \\
\hline Constant & .748 & .248 & 3.018 & .003 & .260 & 1.235 \\
\hline Friendship $(a)$ & .746 & .040 & 18.684 & $<.001$ & .667 & .824 \\
\hline Time working with supervisor & .458 & .165 & 2.779 & .006 & .133 & .782 \\
\hline Telecommuter status & .005 & .141 & 0.033 & .974 & -.273 & .282 \\
\hline Country & .367 & .144 & 2.554 & .011 & .084 & .649 \\
\hline \multicolumn{7}{|c|}{$\begin{aligned} Y & =\text { Job Satisfaction } \\
F(5,282) & =237.729, p<.001, R^{2}=.808, \text { Adjusted } R^{2}=.805\end{aligned}$} \\
\hline Constant & 1.387 & .151 & 9.177 & $<.001$ & 1.089 & 1.684 \\
\hline Identification $(b)$ & .806 & .036 & 22.596 & $<.001$ & .736 & .877 \\
\hline Friendship $\left(c^{\prime}\right)$ & .002 & .036 & 0.054 & .957 & -.069 & .072 \\
\hline Time working with supervisor & -.051 & .100 & -0.506 & .613 & -.248 & .147 \\
\hline Telecommuter status & -.287 & .085 & -3.389 & .001 & -.454 & -.120 \\
\hline Country & .053 & .087 & 0.604 & .546 & -.119 & .224 \\
\hline
\end{tabular}

Note. Identification $=$ organizational identification. Time working with supervisor $=$ length of time working with supervisor. 
mentoring functions.

Communication satisfaction. The second series of simple mediation model analyses tested the indirect effect of the five career development and the four psychosocial mentoring functions on communication satisfaction through organizational identification. Nine simple mediation model analyses were conducted. The first mediation model analysis tested the indirect effect of the sponsorship career development mentoring function on communication satisfaction through organizational identification, controlling for length of time working with their current supervisor, telecommuter status, and country in which their organization is located. Table 22 displays the unstandardized path model coefficients $\left(a, b, c^{\prime}\right)$ and variance accounted for by the variables in the model. The $95 \%$ percentile bootstrap confidence interval provided evidence of an indirect effect as it was entirely above zero [.142, .316], with an indirect effect of $a b=.223$ and a completely standardized indirect effect of $a b_{c s}=.299,95 \%$ CI $[.195, .414]$. The direct effect of the sponsorship career development mentoring function on communication satisfaction was significant $\left(c^{\prime}=.339, p<.001\right)$ and the total effect of the sponsorship career development mentoring function on communication satisfaction was .562 ( $p<$ $.001)$.

The second mediation model analysis tested the indirect effect of the exposure and visibility career development mentoring function on communication satisfaction through organizational identification, controlling for length of time working with their current supervisor, telecommuter status, and country in which their organization is located. Table 23 displays the unstandardized path model coefficients $\left(a, b, c^{\prime}\right)$ and variance accounted for by the variables in the model. The $95 \%$ percentile bootstrap 
Table 22

Unstandardized Path Coefficients for Sponsorship and Communication Satisfaction Model

\begin{aligned} Models $(X=$ Sponsorship) \\ \hline$M=$ Identification \\ $F(4,274)=108.338, p<\end{aligned}$.

$F(4,274)=108.338, p<.001, R^{2}=.613$, Adjusted $R^{2}=.607$

$\begin{array}{llll}\text { Constant } & .810 & .231 & 3.500\end{array}$

Sponsorship (a)

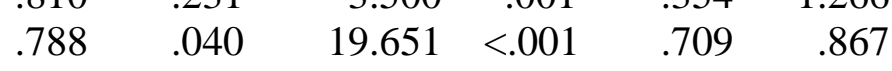

$\begin{array}{llllllll}\text { Time working with supervisor } & .401 & .161 & 2.486 & .014 & .083 & .719\end{array}$

$\begin{array}{lllllll}\text { Telecommuter status } & .100 & .135 & 0.740 & .460 & -.166 & .367\end{array}$

$\begin{array}{lllllll}\text { Country } & .257 & .139 & 1.853 & .065 & -.016 & .530\end{array}$

$Y=$ Communication Satisfaction

$F(5,273)=95.506, p<.001, R^{2}=.636$, Adjusted $R^{2}=.629$

$\begin{array}{lrrrrrr}\text { Constant } & 2.159 & .163 & 13.225 & <.001 & 1.838 & 2.481 \\ \text { Identification }(b) & .283 & .042 & 6.797 & <.001 & .201 & .365 \\ \text { Sponsorship }\left(c^{\prime}\right) & .339 & .043 & 7.893 & <.001 & .255 & .424 \\ \text { Time working with supervisor } & -.024 & .113 & -0.213 & .832 & -.246 & .198 \\ \text { Telecommuter status } & -.335 & .094 & -3.579 & <.001 & -.519 & -.151 \\ \text { Country } & -.275 & .096 & -2.853 & .005 & -.464 & -.085\end{array}$

Note . Identification $=$ organizational identification. Time working with supervisor $=$ length of time working with supervisor. 
Table 23

Unstandardized Path Coefficients for Exposure and Visibility and Communication Satisfaction Model

\begin{tabular}{|c|c|c|c|c|c|c|}
\hline Models $(X=$ Exposure $)$ & Coeff & SE & $t$ & $p$ & LLCI & ULCI \\
\hline \multicolumn{7}{|l|}{$M=$ Identification } \\
\hline \multicolumn{7}{|c|}{$F(4,269)=99.753, p<.001, R^{2}=.597$, Adjusted $R^{2}=.591$} \\
\hline Constant & .926 & .236 & 3.932 & $<.001$ & .463 & 1.390 \\
\hline Exposure $(a)$ & .751 & .040 & 18.835 & $<.001$ & .672 & .829 \\
\hline Time working with supervisor & .608 & .164 & 3.706 & $<.001$ & .285 & .932 \\
\hline Telecommuter status & -.069 & .138 & -0.496 & .620 & -.341 & .203 \\
\hline Country & .037 & .141 & 0.261 & .795 & -.241 & .315 \\
\hline \multicolumn{7}{|c|}{$Y=$ Communication Satisfaction } \\
\hline Constant & 2.168 & .168 & 12.929 & $<.001$ & 1.837 & 2.498 \\
\hline Identification $(b)$ & .300 & .042 & 7.116 & $<.001$ & .217 & .383 \\
\hline Exposure $\left(c^{\prime}\right)$ & .316 & .042 & 7.532 & $<.001$ & .234 & .399 \\
\hline Time working with supervisor & .057 & .116 & 0.493 & .623 & -.172 & .287 \\
\hline Telecommuter status & -.411 & .096 & -4.298 & $<.001$ & -.599 & -.223 \\
\hline Country & -.374 & .098 & -3.830 & $<.001$ & -.567 & -.182 \\
\hline
\end{tabular}

Note . Identification $=$ organizational identification. Exposure $=$ exposure and visibility. Time working with supervisor $=$ length of time working with supervisor. 
confidence interval provided evidence of an indirect effect as it was entirely above zero $[.150, .314]$, with an indirect effect of $a b=.225$ and a completely standardized indirect effect of $a b_{c s}=.314,95 \%$ CI $[.214, .428]$. The direct effect of the exposure and visibility career development mentoring function on communication satisfaction was significant $\left(c^{\prime}\right.$ $=.316, p<.001)$ and the total effect of the exposure and visibility career development mentoring function on communication satisfaction was .542 $(p<.001)$.

The third mediation model analysis tested the indirect effect of the coaching career development mentoring function on communication satisfaction through organizational identification, controlling for length of time working with their current supervisor, telecommuter status, and country in which their organization is located. Table 24 displays the unstandardized path model coefficients $\left(a, b, c^{\prime}\right)$ and variance accounted for by the variables in the model. The $95 \%$ percentile bootstrap confidence interval provided evidence of an indirect effect as it was entirely above zero [.154, .318], with an indirect effect of $a b=.230$ and a completely standardized indirect effect of $a b_{c s}=.318$, $95 \%$ CI $[.220, .429]$. The direct effect of the coaching career development mentoring function on communication satisfaction was significant $\left(c^{\prime}=.302, p<.001\right)$ and the total effect of the coaching career development mentoring function on communication satisfaction was .531 $(p<.001)$.

The fourth mediation model analysis tested the indirect effect of the protection career development mentoring function on communication satisfaction through organizational identification, controlling for length of time working with their current supervisor, telecommuter status, and country in which their organization is located. Table 25 displays the unstandardized path model coefficients $\left(a, b, c^{\prime}\right)$ and variance accounted 
Table 24

Unstandardized Path Coefficients for Coaching and Communication Satisfaction Model

\begin{tabular}{|c|c|c|c|c|c|c|}
\hline Models $(X=$ Coaching $)$ & Coeff & $\mathrm{SE}$ & $t$ & $p$ & LLCI & ULCI \\
\hline \multicolumn{7}{|c|}{$M=$ Identification } \\
\hline \multicolumn{7}{|c|}{$F(4,274)=90.074, p<.001, R^{2}=.568$, Adjusted $R^{2}=.562$} \\
\hline Constant & .974 & .244 & 3.996 & $<.001$ & .494 & 1.453 \\
\hline Coaching $(a)$ & .733 & .041 & 17.839 & $<.001$ & .652 & .814 \\
\hline Time working with supervisor & .467 & .170 & 2.745 & .006 & .132 & .802 \\
\hline Telecommuter status & .048 & .143 & 0.338 & .736 & -.234 & .331 \\
\hline Country & .210 & .147 & 1.430 & .154 & -.079 & .498 \\
\hline \multicolumn{7}{|c|}{$Y=$ Communication Satisfaction } \\
\hline Constant & 2.163 & .164 & 13.153 & $<.001$ & 1.839 & 2.487 \\
\hline Identification $(b)$ & .313 & .040 & 7.899 & $<.001$ & .235 & .391 \\
\hline Coaching $\left(c^{\prime}\right)$ & .302 & .040 & 7.605 & $<.001$ & .223 & .380 \\
\hline Time working with supervisor & -.021 & .113 & -0.186 & .853 & -.244 & .202 \\
\hline Telecommuter status & -.355 & .094 & -3.769 & $<.001$ & -.540 & -.169 \\
\hline Country & -.296 & .097 & -3.068 & .002 & -.486 & -.106 \\
\hline
\end{tabular}

Note. Identification $=$ organizational identification. Time working with supervisor $=$ length of time working with supervisor. 
Table 25

Unstandardized Path Coefficients for Protection and Communication Satisfaction Model

\begin{tabular}{|c|c|c|c|c|c|c|}
\hline Models ( $X=$ Protection $)$ & Coeff & SE & $t$ & $p$ & LLCI & ULCI \\
\hline \multicolumn{7}{|c|}{$M=$ Identification } \\
\hline \multicolumn{7}{|c|}{$F(4.275)=50.938, p<.001, R^{2}=.426$, Adjusted $R^{2}=.418$} \\
\hline Constant & 1.799 & .263 & 6.852 & $<.001$ & 1.282 & 2.315 \\
\hline Protection $(a)$ & .648 & .049 & 13.114 & $<.001$ & .551 & .745 \\
\hline Time working with supervisor & .394 & .197 & 1.999 & .047 & .006 & .782 \\
\hline Telecommuter status & .045 & .165 & 0.271 & .787 & -.281 & .370 \\
\hline Country & .185 & .169 & 1.095 & .275 & -.148 & .517 \\
\hline \multicolumn{2}{|c|}{$F(5,274)=77.641, p<.001, R^{2}=.586$, Adjusted $R^{2}=.578$} & & & & & \\
\hline Constant & 2.345 & .172 & 13.670 & $<.001$ & 2.008 & 2.683 \\
\hline Identification $(b)$ & .427 & .036 & 11.711 & $<.001$ & .355 & .498 \\
\hline Protection $\left(c^{\prime}\right)$ & .181 & .038 & 4.755 & $<.001$ & .106 & .256 \\
\hline Time working with supervisor & -.084 & .120 & -0.701 & .484 & -.320 & .152 \\
\hline Telecommuter status & -.360 & .100 & -3.604 & $<.001$ & -.557 & -.163 \\
\hline Country & -.328 & .102 & -3.208 & .001 & -.529 & -.127 \\
\hline
\end{tabular}

Note. Identification $=$ organizational identification. Time working with supervisor $=$ length of time working with supervisor. 
for by the variables in the model. The $95 \%$ percentile bootstrap confidence interval provided evidence of an indirect effect as it was entirely above zero [.205, .355], with an indirect effect of $a b=.276$ and a completely standardized indirect effect of $a b_{c s}=.371$, $95 \%$ CI $[.284, .465]$. The direct effect of the protection career development mentoring function on communication satisfaction was significant $\left(c^{\prime}=.181, p<.001\right)$ and the total effect of the protection career development mentoring function on communication satisfaction was .457 $(p<.001)$.

The fifth mediation model analysis tested the indirect effect of the challenging assignments career development mentoring function on communication satisfaction through organizational identification, controlling for length of time working with their current supervisor, telecommuter status, and country in which their organization is located. Table 26 displays the unstandardized path model coefficients $\left(a, b, c^{\prime}\right)$ and variance accounted for by the variables in the model. The $95 \%$ percentile bootstrap confidence interval provided evidence of an indirect effect as it was entirely above zero $[.173, .360]$, with an indirect effect of $a b=.260$ and a completely standardized indirect effect of $a b_{c s}=.339,95 \%$ CI $[.236, .455]$. The direct effect of the challenging assignments career development mentoring function on communication satisfaction was significant $\left(c^{\prime}=.282, p<.001\right)$ and the total effect of the challenging assignments career development mentoring function on communication satisfaction was .542 $(p<.001)$.

The sixth mediation model analysis tested the indirect effect of the role modeling psychosocial mentoring function on communication satisfaction through organizational identification, controlling for length of time working with their current supervisor, telecommuter status, and country in which their organization is located. Table 27 displays 
Table 26

Unstandardized Path Coefficients for Challenging Assignments and Communication Satisfaction Model

Models $(X=$ Assignments $)$
$M=$ Identification

$F(4,272)=78.267, p<.001, R^{2}=.535$, Adjusted $R^{2}=.528$

$\begin{array}{lllllll}\text { Constant } & .613 & .275 & 2.228 & .027 & .071 & 1.154\end{array}$

$\begin{array}{lllllll}\text { Assignments }(a) & .750 & .045 & 16.549 & <.001 & .661 & .839\end{array}$

$\begin{array}{lllllll}\text { Time working with supervisor } & .572 & .175 & 3.269 & .001 & .228 & .917\end{array}$

$\begin{array}{lllllll}\text { Telecommuter status } & .096 & .147 & 0.650 & .517 & -.195 & .386\end{array}$

$\begin{array}{lllllll}\text { Country } & .072 & .152 & 0.477 & .634 & -.226 & .371\end{array}$

$Y=$ Communication Satisfaction

$F(5,271)=88.322, p<.001, R^{2}=.620$, Adjusted $R^{2}=.613$

$\begin{array}{lllllll}\text { Constant } & 2.003 & .179 & 11.182 & <.001 & 1.650 & 2.356\end{array}$

$\begin{array}{llllllll}\text { Identification }(b) & .347 & .039 & 8.861 & <.001 & .270 & .424\end{array}$

$\begin{array}{llllllll}\text { Assignments }\left(c^{\prime}\right) & .282 & .041 & 6.803 & <.001 & .200 & .363\end{array}$

$\begin{array}{llllllll}\text { Time working with supervisor } \quad & .012 & .115 & 0.104 & .917 & -.215 & .239\end{array}$

$\begin{array}{llllllll}\text { Telecommuter status } & -.345 & .095 & -3.622 & <.001 & -.533 & -.157\end{array}$

$\begin{array}{llllllll}\text { Country } & -.361 & .098 & -3.690 & <.001 & -.554 & -.169\end{array}$

Note . Identification $=$ organizational identification. Assignments $=$ challenging assignments. Time working with supervisor $=$ length of time working with supervisor. 
Table 27

Unstandardized Path Coefficients for Role Modeling and Communication Satisfaction Model

$\begin{aligned} \text { Models }(X=\text { Role Modeling } & \begin{aligned} M & =\text { Identification } \\ F(4,274) & =108.553, p<.\end{aligned}\end{aligned}$

(6)

Constant

$\begin{array}{lll}1.317 & .213 & 6.193\end{array}$

Role modeling $(a)$ $.684 \quad .035$

$19.678<.001$

.898

1.735

Time working with supervisor $.488 \quad .161$

3.035

$-.053 \quad .136$

.329

.139

$-0.389$

Country

action

$Y=$ Communication Satisfaction

$F(5,273)=109.552, p<.001, R^{2}=.667$, Adjusted $R^{2}=.661$

Constant

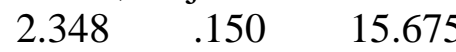

Identification $(b)$

$.237 \quad .040$

$<.001$

2.053

2.643

Role modeling $\left(c^{\prime}\right)$

$.347 \quad .036$

$9.727<.001$

.159

.316

Time working with supervisor

$.024 \quad .108$

$0.221 \quad .825$

.277

.417

Telecommuter status

$-.411$

.090

$-4.575$

$-.189$

.236

Country

$-.226$

.092

$-2.448$

$-.588-.234$

Note . Identification $=$ organizational identification. Time working with supervisor $=$ length of time working with supervisor. 
the unstandardized path model coefficients $\left(a, b, c^{\prime}\right)$ and variance accounted for by the variables in the model. The $95 \%$ percentile bootstrap confidence interval provided evidence of an indirect effect as it was entirely above zero [.101, .233], with an indirect effect of $a b=.162$ and a completely standardized indirect effect of $a b_{c s}=.251,95 \% \mathrm{CI}$ $[.160, .353]$. The direct effect of the role modeling psychosocial mentoring function on communication satisfaction was significant $\left(c^{\prime}=.347, p<.001\right)$ and the total effect of the role modeling psychosocial mentoring function on communication satisfaction was .509 $(p<.001)$

The seventh mediation model analysis tested the indirect effect of the acceptance and confirmation psychosocial mentoring function on communication satisfaction through organizational identification, controlling for length of time working with their current supervisor, telecommuter status, and country in which their organization is located. Table 28 displays the unstandardized path model coefficients $\left(a, b, c^{\prime}\right)$ and variance accounted for by the variables in the model. The $95 \%$ percentile bootstrap confidence interval provided evidence of an indirect effect as it was entirely above zero $[.175, .322]$, with an indirect effect of $a b=.245$ and a completely standardized indirect effect of $a b_{c s}=.278,95 \% \mathrm{CI}[.202, .360]$. The direct effect of the acceptance and confirmation psychosocial mentoring function on communication satisfaction was significant $\left(c^{\prime}=.422, p<.001\right)$ and the total effect of the acceptance and confirmation psychosocial mentoring function on communication satisfaction was .667 $(p<.001)$.

The eighth mediation model analysis tested the indirect effect of the counseling psychosocial mentoring function on communication satisfaction through organizational identification, controlling for length of time working with their current supervisor, 
Table 28

Unstandardized Path Coefficients for Acceptance and Confirmation and Communication Satisfaction Model

Models $(X=$ Acceptance $) \quad$ Coeff $\quad$ SE $\quad t \quad p \quad$ LLCI ULCI

$M=$ Identification

$F(4,272)=82.846, p<.001, R^{2}=.549$, Adjusted $R^{2}=.542$

$\begin{array}{lllllll}\text { Constant } & -.225 & .309 & -0.728 & .467 & -.835 & .384\end{array}$

$\begin{array}{lllllll}\text { Acceptance }(a) & .868 & .051 & 16.992 & <.001 & .767 & .968\end{array}$

$\begin{array}{llllllll}\text { Time working with supervisor } & .422 & .178 & 2.364 & .019 & .071 & .773\end{array}$

$\begin{array}{lllllll}\text { Telecommuter status } & .321 & .146 & 2.202 & .028 & .034 & .609\end{array}$

$\begin{array}{lllllll}\text { Country } & .401 & .150 & 2.679 & .008 & .106 & .696\end{array}$

$Y=$ Communication Satisfaction

$F(5,271)=104.078, p<.001, R^{2}=.658$, Adjusted $R^{2}=.652$

$\begin{array}{lrrrrrr}\text { Constant } & 1.483 & .192 & 7.732 & <.001 & 1.106 & 1.861 \\ \text { Identification }(b) & .282 & .038 & 7.516 & <.001 & .208 & .356 \\ \text { Acceptance }\left(c^{\prime}\right) & .422 & .045 & 9.289 & <.001 & .332 & .511 \\ \text { Time working with supervisor } & -.052 & .112 & -0.465 & .642 & -.272 & .168 \\ \text { Telecommuter status } & -.238 & .091 & -2.609 & .010 & -.417 & -.058 \\ \text { Country } & -.207 & .094 & -2.201 & .029 & -.392 & -.022\end{array}$

Note . Identification $=$ organizational identification. Acceptance $=$ acceptance and confirmation. Time working with supervisor $=$ length of time working with supervisor. 
telecommuter status, and country in which their organization is located. Table 29 displays the unstandardized path model coefficients $\left(a, b, c^{\prime}\right)$ and variance accounted for by the variables in the model. The $95 \%$ percentile bootstrap confidence interval provided evidence of an indirect effect as it was entirely above zero [.124, .260], with an indirect effect of $a b=.185$ and a completely standardized indirect effect of $a b_{c s}=.276,95 \% \mathrm{CI}$ $[.189, .377]$. The direct effect of the counseling psychosocial mentoring function on communication satisfaction was significant $\left(c^{\prime}=.328, p<.001\right)$ and the total effect of the counseling psychosocial mentoring function on communication satisfaction was .513 ( $p<$ $.001)$.

The ninth mediation model analysis tested the indirect effect of the friendship psychosocial mentoring function on communication satisfaction through organizational identification, controlling for length of time working with their current supervisor, telecommuter status, and country in which their organization is located. Table 30 displays the unstandardized path model coefficients $\left(a, b, c^{\prime}\right)$ and variance accounted for by the variables in the model. The $95 \%$ percentile bootstrap confidence interval provided evidence of an indirect effect as it was entirely above zero [.106, .221], with an indirect effect of $a b=.159$ and a completely standardized indirect effect of $a b_{c s}=.219,95 \% \mathrm{CI}$ $[.148, .302]$. The direct effect of the friendship psychosocial mentoring function on communication satisfaction was significant $\left(c^{\prime}=.432, p<.001\right)$ and the total effect of the friendship psychosocial mentoring function on communication satisfaction was .591 ( $p<$ $.001)$.

In sum, the results of this second series of simple mediation model analyses indicate that, controlling for length of time working with their current supervisor, 
Table 29

Unstandardized Path Coefficients for Counseling and Communication Satisfaction Model

\begin{tabular}{|c|c|c|c|c|c|c|}
\hline Models $(X=$ Counseling $)$ & Coeff & $\mathrm{SE}$ & $t$ & $p$ & LLCI & ULCI \\
\hline \multicolumn{7}{|l|}{$M=$ Identification } \\
\hline \multicolumn{7}{|c|}{$F(4,274)=89.085, p<.001, R^{2}=.565$, Adjusted $R^{2}=.559$} \\
\hline Constant & 1.291 & .234 & 5.516 & $<.001$ & .830 & 1.752 \\
\hline Counseling $(a)$ & .679 & .038 & 17.865 & $<.001$ & .604 & .754 \\
\hline Time working with supervisor & .531 & .170 & 3.122 & .002 & .196 & .866 \\
\hline Telecommuter status & -.014 & .143 & -0.097 & .923 & -.295 & .267 \\
\hline Country & .267 & .145 & 1.834 & .068 & -.020 & .553 \\
\hline \multicolumn{7}{|c|}{$Y=$ Communication Satisfaction } \\
\hline Constant & 2.245 & .157 & 14.266 & $<.001$ & 1.935 & 2.555 \\
\hline Identification $(b)$ & .273 & .039 & 7.080 & $<.001$ & .197 & .349 \\
\hline Counseling $\left(c^{\prime}\right)$ & .328 & .036 & 9.191 & $<.001$ & .258 & .398 \\
\hline Time working with supervisor & .032 & .110 & 0.288 & .774 & -.186 & .249 \\
\hline Telecommuter status & -.393 & .091 & -4.321 & $<.001$ & -.572 & -.214 \\
\hline Country & -.267 & .093 & -2.863 & .005 & -.451 & -.083 \\
\hline
\end{tabular}

Note. Identification $=$ organizational identification. Time working with supervisor $=$ length of time working with supervisor. 
Table 30

Unstandardized Path Coefficients for Friendship and Communication Satisfaction Model

\begin{tabular}{|c|c|c|c|c|c|c|}
\hline Models ( $X=$ Friendship) & Coeff & $\mathrm{SE}$ & $t$ & $p$ & LLCI & ULCI \\
\hline \multicolumn{7}{|c|}{$M=$ Identification } \\
\hline \multicolumn{7}{|c|}{$F(4,274)=90.045, p<.001, R^{2}=.568$, Adjusted $R^{2}=.562$} \\
\hline Constant & .769 & .252 & 3.049 & .003 & .273 & 1.266 \\
\hline Friendship $(a)$ & .732 & .041 & 17.830 & $<.001$ & .651 & .813 \\
\hline Time working with supervisor & .498 & .170 & 2.932 & .004 & .164 & .833 \\
\hline Telecommuter status & .019 & .143 & 0.134 & .893 & -.263 & .302 \\
\hline Country & .387 & .146 & 2.646 & .009 & .099 & .676 \\
\hline \multicolumn{7}{|c|}{$Y=$ Communication Satisfaction } \\
\hline Constant & 1.868 & .149 & 12.512 & $<.001$ & 1.574 & 2.161 \\
\hline Identification $(b)$ & .217 & .035 & 6.185 & $<.001$ & .148 & .287 \\
\hline Friendship $\left(c^{\prime}\right)$ & .432 & .035 & 12.297 & $<.001$ & .362 & .501 \\
\hline Time working with supervisor & .022 & .100 & 0.217 & .828 & -.176 & .219 \\
\hline Telecommuter status & -.393 & .083 & -4.713 & $<.001$ & -.558 & -.229 \\
\hline Country & -.186 & .086 & -2.161 & .032 & -.356 & -.017 \\
\hline
\end{tabular}

Note. Identification $=$ organizational identification. Time working with supervisor $=$ length of time working with supervisor. 
telecommuter status, and country in which their organization is located, subordinates' reports of their supervisors' use of the five career development mentoring functions and the four psychosocial mentoring functions positively affects subordinates' communication satisfaction indirectly through their experienced organizational identification. This was true for all five of the career development mentoring functions and for all four of the psychosocial mentoring functions. Although the indirect effects of supervisors' use of the nine mentoring functions on communication satisfaction were smaller than the indirect effects of supervisors' use of the nine mentoring functions on job satisfaction, the use of career development and psychosocial mentoring functions has significant direct effects on subordinates' communication satisfaction.

Organizational commitment. The third series of simple mediation model analyses tested the indirect effect of the five career development and the four psychosocial mentoring functions on organizational commitment through organizational identification. Nine simple mediation model analyses were conducted. The first mediation model analysis tested the indirect effect of the sponsorship career development mentoring function on organizational commitment through organizational identification, controlling for length of time working with their current supervisor, telecommuter status, and country in which their organization is located. Table 31 displays the unstandardized path model coefficients $\left(a, b, c^{\prime}\right)$ and variance accounted for by the variables in the model. The $95 \%$ percentile bootstrap confidence interval provided evidence of an indirect effect as it was entirely above zero $[.522, .713]$, with an indirect effect of $a b=.616$ and a completely standardized indirect effect of $a b_{c s}=.705,95 \%$ CI $[.626,784]$. The direct effect of the sponsorship career development mentoring function on organizational 
Table 31

Unstandardized Path Coefficients for Sponsorship and Organizational Commitment

Model

\begin{aligned} Models $(X=$ Sponsorship) \\ \hline$M=$ Identification \\ $F(4,279)=109.043, p<\end{aligned}$.

$F(4,279)=109.043, p<.001, R^{2}=.610$, Adjusted $R^{2}=.604$

$\begin{array}{llllllll}\text { Constant } & .853 & .231 & 3.694 & <.001 & .399 & 1.308\end{array}$

$\begin{array}{lllllll}\text { Sponsorship }(a) & .795 & .040 & 19.895 & <.001 & .716 & .873\end{array}$

$\begin{array}{llllllll}\text { Time working with supervisor } & .328 & .160 & 2.054 & .041 & .014 & .643\end{array}$

$\begin{array}{lllllll}\text { Telecommuter status } & .074 & .136 & 0.539 & .591 & -.195 & .342\end{array}$

$\begin{array}{llllllll}\text { Country } & .235 & .138 & 1.703 & .090 & -.037 & .508\end{array}$

$Y=$ Organizational Commitment

$F(5,278)=299.555, p<.001, R^{2}=.843$, Adjusted $R^{2}=.840$

$\begin{array}{lllllll}\text { Constant } & 1.034 & .124 & 8.310 & <.001 & .789 & 1.279\end{array}$

$\begin{array}{lllllll}\text { Identification }(b) & .775 & .031 & 24.621 & <.001 & .713 & .837\end{array}$

$\begin{array}{lllllll}\text { Sponsorship }\left(c^{\prime}\right) & -.001 & .033 & -0.020 & .984 & -.065 & .064\end{array}$

$\begin{array}{lllllll}\text { Time working with supervisor } & -.042 & .085 & -0.495 & .621 & -.209 & .125\end{array}$

$\begin{array}{llllllll}\text { Telecommuter status } & -.194 & .072 & -2.705 & .007 & -.336 & -.053\end{array}$

$\begin{array}{llllllll}\text { Country } & -.277 & .073 & -3.796 & <.001 & -.421 & -.134\end{array}$

Note . Identification $=$ organizational identification. Time working with supervisor $=$ length of time working with supervisor. 
commitment was not significant $\left(c^{\prime}=-.001, p=.984\right)$ and the total effect of the sponsorship career development mentoring function on organizational commitment was $.616(p<.001)$.

The second mediation model analysis tested the indirect effect of the exposure and visibility career development mentoring function on organizational commitment through organizational identification, controlling for length of time working with their current supervisor, telecommuter status, and country in which their organization is located. Table 32 displays the unstandardized path model coefficients $\left(a, b, c^{\prime}\right)$ and variance accounted for by the variables in the model. The $95 \%$ percentile bootstrap confidence interval provided evidence of an indirect effect as it was entirely above zero $[.476, .665]$, with an indirect effect of $a b=.568$ and a completely standardized indirect effect of $a b_{c s}=.691,95 \% \mathrm{CI}[.600, .785]$. The direct effect of the exposure and visibility career development mentoring function on organizational commitment was not significant $\left(c^{\prime}=.028, p=.373\right)$ and the total effect of the exposure and visibility career development mentoring function on organizational commitment was .596 $(p<.001)$.

The third mediation model analysis tested the indirect effect of the coaching career development mentoring function on organizational commitment through organizational identification, controlling for length of time working with their current supervisor, telecommuter status, and country in which their organization is located. Table 33 displays the unstandardized path model coefficients $\left(a, b, c^{\prime}\right)$ and variance accounted for by the variables in the model. The $95 \%$ percentile bootstrap confidence interval provided evidence of an indirect effect as it was entirely above zero [.456, .629], with an indirect effect of $a b=.540$ and a completely standardized indirect effect of $a b_{c s}=.643$, 
Table 32

Unstandardized Path Coefficients for Exposure and Visibility and Organizational

Commitment Model

\begin{tabular}{|c|c|c|c|c|c|c|}
\hline Models $(X=$ Exposure $)$ & Coeff & $\mathrm{SE}$ & $t$ & $p$ & LLCI & ULCI \\
\hline \multicolumn{7}{|l|}{$M=$ Identification } \\
\hline \multicolumn{7}{|c|}{$F(4,274)=103.789, p<.001, R^{2}=.602$, Adjusted $R^{2}=.596$} \\
\hline Constant & .964 & .232 & 4.155 & $<.001$ & .507 & 1.421 \\
\hline Exposure $(a)$ & .759 & .039 & 19.410 & $<.001$ & .682 & .836 \\
\hline Time working with supervisor & .519 & .161 & 3.223 & .001 & .202 & .836 \\
\hline Telecommuter status & -.063 & .138 & -0.456 & .648 & -.334 & .208 \\
\hline Country & -.001 & .140 & -0.010 & .992 & -.276 & .273 \\
\hline \multicolumn{7}{|c|}{$Y=$ Organizational Commitment } \\
\hline Constant & 1.024 & .126 & 8.140 & $<.001$ & .777 & 1.272 \\
\hline Identification $(b)$ & .748 & .032 & 23.541 & $<.001$ & .686 & .811 \\
\hline Exposure $\left(c^{\prime}\right)$ & .028 & .032 & 0.893 & .373 & -.034 & .091 \\
\hline Time working with supervisor & -.023 & .086 & -0.268 & .789 & -.193 & .147 \\
\hline Telecommuter status & -.205 & .072 & -2.827 & .005 & -.348 & -.062 \\
\hline Country & -.286 & .073 & -3.893 & $<.001$ & -.430 & -.141 \\
\hline
\end{tabular}

Note. Identification $=$ organizational identification. Exposure $=$ exposure and visibility. Time working with supervisor $=$ length of time working with supervisor. 
Table 33

Unstandardized Path Coefficients for Coaching and Organizational Commitment Model

\begin{tabular}{|c|c|c|c|c|c|c|}
\hline Models $(X=$ Coaching $)$ & Coeff & $\mathrm{SE}$ & $t$ & $p$ & LLCI & ULCI \\
\hline \multicolumn{7}{|l|}{$M=$ Identification } \\
\hline \multicolumn{7}{|c|}{$F(4,279)=87.872, p<.001, R^{2}=.557$, Adjusted $R^{2}=.551$} \\
\hline Constant & 1.059 & .244 & 4.333 & $<.001$ & .578 & 1.540 \\
\hline Coaching $(a)$ & .727 & .041 & 17.773 & $<.001$ & .646 & .808 \\
\hline Time working with supervisor & .419 & .170 & 2.468 & .014 & .085 & .753 \\
\hline Telecommuter status & .088 & .145 & 0.603 & .547 & -.198 & .374 \\
\hline Country & .162 & .147 & 1.100 & .272 & -.128 & .452 \\
\hline \multicolumn{7}{|c|}{$\begin{aligned} Y & =\text { Organizational Commitment } \\
F(5,278) & =302.327, p<.001, R^{2}=.845, \text { Adjusted } R^{2}=.842\end{aligned}$} \\
\hline Constant & .974 & .124 & 7.847 & $<.001$ & .730 & 1.219 \\
\hline Identification $(b)$ & .743 & .029 & 25.222 & $<.001$ & .685 & .801 \\
\hline Coaching $\left(c^{\prime}\right)$ & .044 & .029 & 1.491 & .137 & -.014 & .102 \\
\hline Time working with supervisor & -.036 & .084 & -0.424 & .672 & -.202 & .130 \\
\hline Telecommuter status & -.198 & .071 & -2.764 & .006 & -.338 & -.057 \\
\hline Country & -.276 & .073 & -3.801 & $<.001$ & -.419 & -.133 \\
\hline
\end{tabular}

Note. Identification $=$ organizational identification. Time working with supervisor $=$ length of time working with supervisor. 
$95 \%$ CI $[.564, .724]$. The direct effect of the coaching career development mentoring function on organizational commitment was not significant $\left(c^{\prime}=.044, p=.137\right)$ and the total effect of the coaching career development mentoring function on organizational commitment was $.584(p<.001)$.

The fourth mediation model analysis tested the indirect effect of the protection career development mentoring function on organizational commitment through organizational identification, controlling for length of time working with their current supervisor, telecommuter status, and country in which their organization is located. Table 34 displays the unstandardized path model coefficients $\left(a, b, c^{\prime}\right)$ and variance accounted for by the variables in the model. The $95 \%$ percentile bootstrap confidence interval provided evidence of an indirect effect as it was entirely above zero $[.448, .631]$, with an indirect effect of $a b=.537$ and a completely standardized indirect effect of $a b_{c s}=.610$, $95 \%$ CI $[.519, .697]$. The direct effect of the protection career development mentoring function on organizational commitment was not significant $\left(c^{\prime}=-.035, p=.203\right)$ and the total effect of the protection career development mentoring function on organizational commitment was $.502(p<.001)$.

The fifth mediation model analysis tested the indirect effect of the challenging assignments career development mentoring function on organizational commitment through organizational identification, controlling for length of time working with their current supervisor, telecommuter status, and country in which their organization is located. Table 35 displays the unstandardized path model coefficients $\left(a, b, c^{\prime}\right)$ and variance accounted for by the variables in the model. The $95 \%$ percentile bootstrap confidence interval provided evidence of an indirect effect as it was entirely above zero 
Table 34

Unstandardized Path Coefficients for Protection and Organizational Commitment Model

\begin{tabular}{|c|c|c|c|c|c|c|}
\hline Models ( $X=$ Protection $)$ & Coeff & $\mathrm{SE}$ & $t$ & $p$ & LLCI & ULCI \\
\hline \multicolumn{7}{|c|}{$M=$ Identification } \\
\hline \multicolumn{7}{|c|}{$F(4,280)=54.594, p<.001, R^{2}=.438$, Adjusted $R^{2}=.430$} \\
\hline Constant & 1.764 & .260 & 6.791 & $<.001$ & 1.252 & 2.275 \\
\hline Protection $(a)$ & .675 & .049 & 13.800 & $<.001$ & .579 & .771 \\
\hline Time working with supervisor & .282 & .192 & 1.465 & .144 & -.097 & .661 \\
\hline Telecommuter status & .062 & .164 & 0.367 & .714 & -.262 & .383 \\
\hline Country & .164 & .166 & 0.991 & .323 & -.162 & .491 \\
\hline \multicolumn{7}{|c|}{$\begin{aligned} Y & =\text { Organizational Commitment } \\
F(5,279) & =303.457, p<.001, R^{2}=.845, \text { Adjusted } R^{2}=.842\end{aligned}$} \\
\hline Constant & 1.075 & .122 & 8.781 & $<.001$ & .834 & 1.316 \\
\hline Identification $(b)$ & .796 & .026 & 30.506 & $<.001$ & .745 & .848 \\
\hline Protection $\left(c^{\prime}\right)$ & -.035 & .028 & -1.277 & .203 & -.090 & .019 \\
\hline Time working with supervisor & -.035 & .084 & -0.411 & .681 & -.201 & .131 \\
\hline Telecommuter status & -.189 & .072 & -2.634 & .009 & -.330 & -.048 \\
\hline Country & -.277 & .073 & -3.818 & $<.001$ & -.420 & -.134 \\
\hline
\end{tabular}

Note. Identification $=$ organizational identification. Time working with supervisor $=$ length of time working with supervisor. 
Table 35

Unstandardized Path Coefficients for Challenging Assignments and Organizational

Commitment Model

Models $(X=$ Assignments $) \quad$ Coeff $\quad$ SE $\quad t \quad p \quad$ LLCI ULCI

$M=$ Identification

$F(4,276)=81.013, p<.001, R^{2}=.540$, Adjusted $R^{2}=.533$

$\begin{array}{lllllll}\text { Constant } & .619 & .273 & 2.270 & .024 & .082 & 1.156\end{array}$

$\begin{array}{lllllll}\text { Assignments }(a) & .757 & .045 & 17.014 & <.001 & .670 & .845\end{array}$

$\begin{array}{llllllll}\text { Time working with supervisor } & .529 & .172 & 3.076 & .002 & .191 & .868\end{array}$

$\begin{array}{lllllll}\text { Telecommuter status } & .125 & .148 & 0.846 & .398 & -.166 & .415\end{array}$

$\begin{array}{lllllll}\text { Country } & .035 & .151 & 0.233 & .816 & -.261 & .331\end{array}$

$Y=$ Organizational Commitment

$F(5,275)=302.486, p<.001, R^{2}=.846$, Adjusted $R^{2}=.843$

$\begin{array}{llllllll}\text { Constant } & .884 & .132 & 6.704 & <.001 & .624 & 1.143\end{array}$

$\begin{array}{lllllll}\text { Identification }(b) & .713 & .029 & 24.756 & <.001 & .657 & .770\end{array}$

$\begin{array}{lllllll}\text { Assignments }\left(c^{\prime}\right) & .085 & .031 & 2.796 & .006 & .025 & .145\end{array}$

$\begin{array}{lllllll}\text { Time working with supervisor } & -.009 & .084 & -0.108 & .914 & -.174 & .156\end{array}$

$\begin{array}{llllllll}\text { Telecommuter status } & -.204 & .071 & -2.891 & .004 & -.344 & -.065\end{array}$

$\begin{array}{llllllll}\text { Country } & -.298 & .072 & -4.133 & <.001 & -.440 & -.156\end{array}$

Note . Identification $=$ organizational identification. Assignments $=$ challenging assignments.

Time working with supervisor $=$ length of time working with supervisor. 
[.457, .629], with an indirect effect of $a b=.540$ and a completely standardized indirect effect of $a b_{c s}=.610,95 \% \mathrm{CI}[.533, .684]$. The direct effect of the challenging assignments career development mentoring function on organizational commitment was significant $\left(c^{\prime}=.085, p=.006\right)$ and the total effect of the challenging assignments career development mentoring function on organizational commitment was .626 $(p<.001)$.

The sixth mediation model analysis tested the indirect effect of the role modeling psychosocial mentoring function on organizational commitment through organizational identification, controlling for length of time working with their current supervisor, telecommuter status, and country in which their organization is located. Table 36 displays the unstandardized path model coefficients $\left(a, b, c^{\prime}\right)$ and variance accounted for by the variables in the model. The $95 \%$ percentile bootstrap confidence interval provided evidence of an indirect effect as it was entirely above zero [.450, .604], with an indirect effect of $a b=.526$ and a completely standardized indirect effect of $a b_{c s}=.691,95 \% \mathrm{CI}$ $[.616, .768]$. The direct effect of the role modeling psychosocial mentoring function on organizational commitment was not significant $\left(c^{\prime}=.027, p=.353\right)$ and the total effect of the role modeling psychosocial mentoring function on organizational commitment was $.552(p<.001)$.

The seventh mediation model analysis tested the indirect effect of the acceptance and confirmation psychosocial mentoring function on organizational commitment through organizational identification, controlling for length of time working with their current supervisor, telecommuter status, and country in which their organization is located. Table 37 displays the unstandardized path model coefficients $\left(a, b, c^{\prime}\right)$ and variance accounted for by the variables in the model. The $95 \%$ percentile bootstrap 
Table 36

Unstandardized Path Coefficients for Role Modeling and Organizational Commitment Model

Models $(X=$ Role Modeling $) \quad$ Coeff $\quad$ SE $\quad t \quad p \quad$ LLCI $\quad$ ULCI

$M=$ Identification

$F(4,279)=113.910, p<.001, R^{2}=.620$, Adjusted $R^{2}=.615$

$\begin{array}{lllllll}\text { Constant } & 1.300 & .211 & 6.172 & <.001 & .885 & 1.714\end{array}$

$\begin{array}{llllllll}\text { Role modeling }(a) & 699 & .034 & 20.358 & <.001 & .631 & .766\end{array}$

$\begin{array}{lllllll}\text { Time working with supervisor } & .431 & .157 & 2.741 & .007 & .121 & .741\end{array}$

$\begin{array}{lllllll}\text { Telecommuter status } & -.059 & .135 & -0.436 & .663 & -.326 & .208\end{array}$

$\begin{array}{lllllll}\text { Country } & .315 & .136 & 2.309 & .022 & .046 & .584\end{array}$

$Y=$ Organizational Commitment

$F(5,278)=301.396, p<.001, R^{2}=.844$, Adjusted $R^{2}=.841$

$\begin{array}{llllllll}\text { Constant } & 1.014 & .119 & 8.491 & <.001 & .779 & 1.249\end{array}$

$\begin{array}{lllllll}\text { Identification }(b) & .752 & .032 & 23.616 & <.001 & .690 & .815\end{array}$

$\begin{array}{lllllll}\text { Role modeling }\left(c^{\prime}\right) & .027 & .029 & 0.931 & .353 & -.030 & .083\end{array}$

$\begin{array}{lllllll}\text { Time working with supervisor } & -.035 & .085 & -0.412 & .681 & -.202 & .132\end{array}$

$\begin{array}{lllllll}\text { Telecommuter status } & -.202 & .072 & -2.806 & .005 & -.344 & -.060\end{array}$

$\begin{array}{lllllll}\text { Country } & -.271 & .073 & -3.698 & <.001 & -.415 & -.127\end{array}$

Note . Identification $=$ organizational identification. Time working with supervisor $=$ length of time working with supervisor. 
Table 37

Unstandardized Path Coefficients for Acceptance and Confirmation and Organizational

Commitment Model

Models $(X=$ Acceptance $) \quad$ Coeff $\quad$ SE $\quad t \quad p \quad$ LLCI $\quad$ ULCI

$M=$ Identification

$F(4,277)=87.313, p<.001, R^{2}=.558$, Adjusted $R^{2}=.552$

$\begin{array}{lllllll}\text { Constant } & -.229 & .304 & -0.753 & .452 & -.828 & .370\end{array}$

$\begin{array}{lllllll}\text { Acceptance }(a) & .876 & .050 & 17.662 & <.001 & .778 & .973\end{array}$

$\begin{array}{lllllll}\text { Time working with supervisor } & .404 & .174 & 2.327 & .021 & .062 & .746\end{array}$

$\begin{array}{lllllll}\text { Telecommuter status } & .273 & .145 & 1.880 & .061 & -.013 & .558\end{array}$

$\begin{array}{lllllll}\text { Country } & .465 & .148 & 3.153 & .002 & .175 & .756\end{array}$

$Y=$ Organizational Commitment

$F(5,276)=298.859, p<.001, R^{2}=.844$, Adjusted $R^{2}=.841$

$\begin{array}{lllllll}\text { Constant } & 1.162 & .150 & 7.745 & <.001 & .866 & 1.457\end{array}$

$\begin{array}{lllllll}\text { Identification }(b) & .801 & .030 & 27.078 & <.001 & .743 & .859\end{array}$

$\begin{array}{lllllll}\text { Acceptance }\left(c^{\prime}\right) & -.043 & .036 & -1.221 & .223 & -.114 & .027\end{array}$

$\begin{array}{lllllll}\text { Time working with supervisor } & -.061 & .086 & -0.706 & .481 & -.231 & .109\end{array}$

$\begin{array}{lllllll}\text { Telecommuter status } & -.202 & .072 & -2.805 & .005 & -.343 & -.060\end{array}$

$\begin{array}{lllllll}\text { Country } & -.293 & .074 & -3.963 & <.001 & -.439 & -.147\end{array}$

Note . Identification $=$ organizational identification. Acceptance $=$ acceptance and confirmation.

Time working with supervisor $=$ length of time working with supervisor. 
confidence interval provided evidence of an indirect effect as it was entirely above zero $[.613, .799]$, with an indirect effect of $a b=.701$ and a completely standardized indirect effect of $a b_{c s}=.687,95 \%$ CI $[.605, .770]$. The direct effect of the acceptance and confirmation psychosocial mentoring function on organizational commitment was not significant $\left(c^{\prime}=-.043, p=.223\right)$ and the total effect of the acceptance and confirmation psychosocial mentoring function on organizational commitment was .658 $(p<.001)$.

The eighth mediation model analysis tested the indirect effect of the counseling psychosocial mentoring function on organizational commitment through organizational identification, controlling for length of time working with their current supervisor, telecommuter status, and country in which their organization is located. Table 38 displays the unstandardized path model coefficients $\left(a, b, c^{\prime}\right)$ and variance accounted for by the variables in the model. The $95 \%$ percentile bootstrap confidence interval provided evidence of an indirect effect as it was entirely above zero [.446, .614], with an indirect effect of $a b=.528$ and a completely standardized indirect effect of $a b_{c s}=.680,95 \% \mathrm{CI}$ $[.595, .763]$. The direct effect of the counseling psychosocial mentoring function on organizational commitment was not significant $\left(c^{\prime}=.007, p=.803\right)$ and the total effect of the counseling psychosocial mentoring function on organizational commitment was .535 $(p<.001)$.

The ninth mediation model analysis tested the indirect effect of the friendship psychosocial mentoring function on organizational commitment through organizational identification, controlling for length of time working with their current supervisor, telecommuter status, and country in which their organization is located. Table 39 displays the unstandardized path model coefficients $\left(a, b, c^{\prime}\right)$ and variance accounted for by the 
Table 38

Unstandardized Path Coefficients for Counseling and Organizational Commitment Model

Models $(X=$ Counseling $)$

Coeff SE

$t$

$p \quad$ LLCI

ULCI

$M=$ Identification

$F(4,279)=94.597, p<.001, R^{2}=.576$, Adjusted $R^{2}=.570$

Constant

$$
1.309
$$

.229

.686

.037

$5.706<.001$

.857

1.761

Counseling $(a)$

$\begin{array}{llll}.476 & .166 & 2.874 & 004\end{array}$

$.613 \quad .758$

Time working with supervisor

Telecommuter status

$-.024 \quad .141$

$-0.173$

.246

.143

1.720

.150

.803

Country

tment

$Y=$ Organizational Commitment

$F(5,278)=295.451, p<.001, R^{2}=.842$, Adjusted $R^{2}=.839$

Constant

$1.018 \quad .123 \quad 8.247$

Identification $(b)$

$.770 \quad .030$

25.265

$<.001$

.775

1.261

Counseling $\left(c^{\prime}\right)$

$.007 \quad .028$

0.249

$<.001$

.710

.830

Time working with supervisor

$$
-.036 \quad .086
$$

$-0.420$

.803

$-.048$

.062

Telecommuter status

$-.196$

.072

$-2.728$

.675

$-.205$

.133

Country

$-.277$

.073

$-3.793$

$-.338$

$-.055$

Note . Identification $=$ organizational identification. Time working with supervisor $=$ length of time working with supervisor. 
Table 39

Unstandardized Path Coefficients for Friendship and Organizational Commitment Model

\begin{tabular}{|c|c|c|c|c|c|c|}
\hline Models ( $X=$ Friendship) & Coeff & SE & $t$ & $p$ & LLCI & ULCI \\
\hline \multicolumn{7}{|l|}{$M=$ Identification } \\
\hline \multicolumn{7}{|c|}{$F(4,279)=95.152, p<.001, R^{2}=.577$, Adjusted $R^{2}=.571$} \\
\hline Constant & .759 & .249 & 3.051 & .002 & .269 & 1.249 \\
\hline Friendship $(a)$ & .743 & .040 & 18.531 & $<.001$ & .664 & .822 \\
\hline Time working with supervisor & .454 & .166 & 2.735 & .007 & .127 & .780 \\
\hline Telecommuter status & .008 & .142 & 0.056 & .956 & -.273 & .288 \\
\hline Country & .366 & .144 & 2.545 & .011 & .083 & .650 \\
\hline \multicolumn{6}{|c|}{$Y=$ Organizational Commitment } & $F(5,278)=301.824, p<.001, R^{2}=.844$, Adjusted $R^{2}=.841$ \\
\hline Constant & 1.094 & .127 & 8.587 & $<.001$ & .843 & 1.345 \\
\hline Identification $(b)$ & .804 & .030 & 26.657 & $<.001$ & .745 & .863 \\
\hline Friendship $\left(c^{\prime}\right)$ & -.039 & .030 & -1.285 & .200 & -.098 & .021 \\
\hline Time working with supervisor & -.049 & .085 & -0.580 & .563 & -.216 & .118 \\
\hline Telecommuter status & -.188 & .072 & -2.621 & .009 & -.329 & -.047 \\
\hline Country & -.290 & .073 & -3.954 & $<.001$ & -.434 & -.146 \\
\hline
\end{tabular}

Note. Identification $=$ organizational identification. Time working with supervisor $=$ length of time working with supervisor. 
variables in the model. The $95 \%$ percentile bootstrap confidence interval provided evidence of an indirect effect as it was entirely above zero [.512, .685], with an indirect effect of $a b=.598$ and a completely standardized indirect effect of $a b_{c s}=.707,95 \% \mathrm{CI}$ $[.619, .791]$. The direct effect of the friendship psychosocial mentoring function on organizational commitment was not significant $\left(c^{\prime}=-.039, p=.200\right)$ and the total effect of the friendship psychosocial mentoring function on organizational commitment was $.559(p<.001)$.

In sum, the results of this third series of simple mediation model analyses indicate that, controlling for length of time working with their current supervisor, telecommuter status, and country in which their organization is located, subordinates' reports of their supervisors' use of the five career development mentoring functions and the four psychosocial mentoring functions positively affects subordinates' organizational commitment indirectly through their experienced organizational identification. This was true for all five of the career development mentoring functions and for all four of the psychosocial mentoring functions.

\section{Summary}

This chapter detailed the results of the preliminary and primary analyses employed to address the four hypotheses. Hypothesis one found that subordinates who perceive their superiors as enacting the five career development mentoring functions and the four psychosocial mentoring functions more highly identify with their organization. Hypothesis two found that subordinate organizational identification is associated positively with job satisfaction, communication satisfaction with superiors, and organizational commitment. Hypothesis three found that subordinate perceptions of 
superiors' enactment of the five career development mentoring functions and the four psychosocial mentoring functions is associated positively with subordinates' job satisfaction, communication satisfaction with superiors, and organizational commitment. The fourth hypothesis found that subordinate perceptions of superiors' enactment of the five career development mentoring functions and the four psychosocial mentoring functions affects indirectly job satisfaction, communication satisfaction with their superior, and organizational commitment through subordinates' organizational identification; however, superiors' enactment of the nine mentoring functions also had a direct effect on subordinates' communication satisfaction with that superior. The results of these analyses indicate support for all four hypotheses. 


\section{CHAPTER IV}

Discussion

This dissertation examined the relationships between subordinates' perceptions of their superiors' provision of the five career development mentoring functions and the four psychosocial mentoring functions, and subordinates' subsequent self-reports of their organizational identification, job satisfaction, communication satisfaction, and organizational commitment. Two general findings were obtained. First, superiors' provision of mentoring functions is associated positively with subordinates' organizational identification, job satisfaction, communication satisfaction, and organizational commitment. Second, superiors' employment of the five career development mentoring functions and the four psychosocial mentoring functions influences indirectly subordinates' job satisfaction, communication satisfaction, and organizational commitment through subordinates' increased organizational identification. Superiors' employment of the mentoring functions also influences directly subordinates' communication satisfaction. Collectively, these findings suggest that the provision of mentoring functions from superiors enhances subordinates' job satisfaction, communication satisfaction, and organizational commitment by increasing the extent to which subordinates identify with their organization.

This chapter contains four sections. The first section explicates the results from analysis of the first three hypotheses, the second section provides possible explanations for the indirect and direct effects resulting from analysis of the fourth hypothesis, the third section identifies several limitations of this dissertation, and the fourth section offers several avenues for future research regarding mentoring functions, organizational 
identification, and subordinates' workplace outcomes.

\section{Hypotheses One, Two, and Three}

The first hypothesis proposed that subordinates who perceive their superiors as enacting the five career development mentoring functions and the four psychosocial mentoring functions would more highly identify with their organization; the second hypothesis proposed that subordinates' organizational identification would be associated positively with their job satisfaction, communication satisfaction with superiors, and organizational commitment; and the third hypothesis proposed that subordinate perceptions of superiors' enactment of the mentoring functions would be associated positively with subordinates' job satisfaction, communication satisfaction with superiors, and organizational commitment. These three hypotheses were supported.

The positive relationships found between superiors' enactment of the mentoring functions, subordinates' organizational identification, and subordinates' workplace outcomes may be explained by establishing and attaining goals that align with subordinates' values. The research conducted on goals that align with an individual's values suggest that working toward attaining these goals is associated positively with psychological well-being (Sheldon \& Elliot, 1999). By being provided these mentoring functions from an organizational member who is more advanced and likely more successful in the profession subordinates are likely to experience satisfaction associated with working toward (and achieving) career development and psychosocial goals. Organizational members who perceive that their jobs facilitate attainment of goals relevant to their self-concept typically are satisfied with their jobs, satisfied with their superiors, and committed to their organization (Bono \& Judge, 2003; Judge, Bono, Erez, 
\& Locke, 2005). Therefore, it follows that mentoring functions that facilitate these goals would be associated positively with organizational identification, job satisfaction, communication satisfaction, and organizational commitment.

Two implications arise from the collective results of these hypotheses. First, these results suggest that when subordinates perceive their superiors as having a vested interest in their organizational success, they experience positive workplace outcomes. Previous organizational research findings have established that when individuals perceive organizational management as investing in the career growth and development of its employees, they are more satisfied with their jobs, more committed to the organization, and less likely to leave the organization (Kuvaas \& Dysvik, 2010; Lee \& Bruvold, 2003). By providing subordinates with career development and psychosocial mentoring, superiors demonstrate their interest and investment in the success of the subordinate. Second, the positive relationships obtained between the five career development and the four psychosocial mentoring functions, organizational identification, job satisfaction, communication satisfaction, and organizational commitment may be indicative of the type of organizational culture that the provision of mentoring functions fosters. Organizational culture refers to the set of assumptions, values, and artifacts that emerge from communicative interactions within the organization, which enable organizational members to make sense of their workplace experiences (Keyton 2014; Pacanowsky \& O'Donnell-Trujillo, 1982). Organizational culture has been linked with employees' positive workplace experiences throughout previous organizational research. Specifically, employees' perceptions of morale (i.e., a perceived relationship of trust and respect between organizational management and workers) is associated positively with 
employees' organizational identification (Schrodt, 2002). Workplace cultures in which employees feel safe to take social and career risks promote learning and growth from these risks, employee engagement, and performance (Carmeli \& Gittell, 2009; Dollard \& Bakker, 2010; Hirak, Peng, Carmeli, \& Schaubroeck, 2012). Furthermore, supportive (i.e., cultures that promote collaboration and teamwork), rewarding (i.e., cultures that promote professional growth and employee development) and stable (i.e., cultures that promote perceptions of job security) organizational cultures are associated positively with employees' trust toward, satisfaction with, and commitment to their organization (Men \& Jiang, 2016). Perhaps mentoring from superiors enables subordinates to perceive an organizational culture in which subordinates trust and feel supported and respected by management. These perceptions also likely enhance subordinates' positive workplace experiences.

\section{Hypothesis Four}

The fourth hypothesis proposed that subordinate perceptions of superiors' enactment of the five career development mentoring functions and the four psychosocial mentoring functions would affect indirectly subordinate job satisfaction, communication satisfaction with their superior, and organizational commitment through subordinates' organizational identification; this hypothesis was supported. That is, superiors' provision of both career development and psychosocial mentoring increased subordinates' job satisfaction, communication satisfaction, and organizational commitment indirectly through subordinates' increased organizational identification. Superiors' provision of mentoring did not affect directly subordinates' job satisfaction or organizational commitment, but did affect directly subordinates' communication satisfaction with their 
superiors.

The indirect effects found by analyzing the fourth hypothesis may be best explained by the positive emotions and meaning that subordinates attribute to their work. Employees who perceive their work as meaningful believe that their work has personal significance, contributes to the meaning of their lives as a whole, and has a positive impact on others (Steger, Dik, \& Duffy, 2012). Furthermore, meaningful work is generally purpose-driven and directed toward personal growth (Rosso, Dekas, \& Wrzesniewski, 2010; Steger et al.), and the perception of meaningful work is associated positively with employees' well-being in the workplace (Arnold, Turner, Barling, Kelloway, \& McKee, 2007). Employees value experiences in the workplace that elicit positive emotions (Lutgen-Sandvik, Riforgiate, \& Fletcher, 2011). Lutgen-Sandvik et al. found that employees value specifically feeling recognized and appreciated for their unique worth within the organization, having power and control with respect to their jobs, finding achievement, success, and personal fulfillment from their work, cultivating and developing meaningful connections with others within the workplace, and feeling safe and protected from negative events at work.

Although previous research has not examined the provision of mentoring functions and employees' perceptions of positive emotion and meaningful work specifically, social interactions within the workplace and perceived self-efficacy and selfesteem enable employees to find value and meaning in their work (Lutgen-Sandvik et al. 2011; Rosso et al., 2010). Furthermore, perhaps mentoring functions allow subordinates to find value in the work, as mentoring enables employees to feel appreciated, empowered, successful, connected with others, and protected from negative events. 
The evidence of a direct effect of superiors' provision of career development and psychosocial mentoring on subordinates' communication satisfaction--and the lack of a direct effect of mentoring functions on job satisfaction and organizational commitment-may be best explained by the conceptual differences that exist among communication satisfaction, job satisfaction, and organizational commitment. Although job satisfaction and organizational commitment are centered on individuals' role and membership within an organization, communication satisfaction with superiors is influenced more so by the interpersonal nature of the superior-subordinate relationship, irrespective of job tasks and the organization. Employees who are satisfied with their communication within their organization feel supported by management and guided by their superiors (Downs \& Hazen, 1977), which is also emulated through superiors' mentoring. Furthermore, satisfying communication is perceived as assisting employees by providing information regarding their jobs and organization as well as fulfilling interpersonal needs (Madlock, 2008; Putti, Aryee, \& Phua, 1990; Steele \& Plenty, 2015). As communication from superiors is important to subordinates in that superiors provide information necessary to function and make sense of subordinates' experiences within the organization and related to their job roles (Sias, 2009), perhaps mentoring from superiors is a way in which superiors provide this important information while also fulfilling subordinates professional, relational, and psychosocial needs.

However, it may be that employees reap the benefits of mentoring toward their career development and personal growth, but remain relatively detached from their current employment. Relatedly, employees who view their careers as guided by their personal values and goals, as opposed to organizational or professional standards, tend to 
experience less job satisfaction and organizational commitment (Supeli \& Creed, 2016), suggesting that although communication from superiors enables subordinates to function effectively within the organization, subordinates with career goals outside of the constraints of their organization may not be fulfilled by either their job or organizational membership.

Two implications arise from the results of the fourth hypothesis. First, evidence of an indirect effect of mentoring on workplace outcomes through organizational identification stresses the importance for employees to be personally connected to their role within the workplace (e.g., through organizational identification) in some way. That is, these results suggest that in order to experience fully the benefits of superior mentoring, employees also need to perceive an overlap between what their organizations represent and how they identify themselves. Organizations whose employees are engaged in and satisfied with their jobs typically are more committed to the organization and perform at a higher level (Harter, Schmidt, \& Hayes, 2002). As organizational identification involves perceiving the needs of the organization as their own (Cheney, 1983a, 1983b; Ashforth \& Mael, 1989) and experiencing feelings of oneness with, loyalty to, and shared characteristics with the organization (Patchen, 1970), perhaps the close association between employees' needs and characteristics and the organizations' needs and characteristics enables employees to connect with their jobs on a personal level. The results of the fourth hypothesis corroborate previous organizational research suggesting that superiors' behaviors can enable subordinates to connect personally with their jobs. For example, performance feedback and coaching from superiors are found to increase the extent to which individuals engage with their work (Schaufeli \& Bakker, 
2004). Similarly, the results of this dissertation suggest that the provision of mentoring is one way in which superiors can specifically promote this personal connection to their organization in the form of organizational identification.

Second, as the results suggest the importance of organizational identification to job satisfaction, communication satisfaction, and organizational commitment, organizations should foster environments in which employees are likely to identify with the organization. As there is evidence of an indirect effect of mentoring from superiors on subordinates' positive workplace experiences through their increased organizational identification, creating an environment conducive to increased employee organizational identification may promote job satisfaction, communication satisfaction, and organizational commitment among employees. Superiors can create environments that may increase subordinates' organizational identification by promoting perceptions that subordinates are free to express their opinions (Kassing, 2000a), encouraging social interaction among coworkers (Sias, 2017), and providing easy access to organizational information and demonstrating receptiveness to employee feedback (Reed et al., 2016). By doing so, employees are more likely to identify with their organizations, which may then enhance their workplace experiences.

\section{Limitations}

Although the results of this dissertation provide insight regarding the relationships between superiors' provision of mentoring functions and subordinates' subsequent reports of organizational identification, job satisfaction, communication satisfaction, and organizational commitment, four limitations of this dissertation should be considered. First, one limitation is the potential overlap between the operationalizations of the 
organizational identification construct and the organizational commitment construct. These two constructs often are conceptualized similarly, and confusion regarding their distinction has been raised by organizational researchers (e.g., Ashforth \& Mael, 1989; Gautam, Van Dick, \& Wagner, 2004; Millet et al., 2000; van Knippenberg \& Sleebos, 2006). As noted, organizational identification has been conceptualized as perceived oneness with an individual's organization (Ashforth \& Mael, 1989; Mael \& Ashforth, 1992), belongingness to, loyalty to, and shared characteristics with an individual's organization (Patchen, 1970) and considering the organization's best interests throughout the decision-making process (Cheney 1983a, 1983b), whereas organizational commitment has been conceptualized as specific behaviors and attitudes individuals have toward their organization, such as attachment to the organization's values and a desire to remain an organizational member (Ashforth \& Mael, 1989; Gautam et al., 2004; Van Knippenberg \& Sleebos, 2006). Due to some conceptual overlap in these two constructs, organizational researchers have argued that a more clear distinction between organizational identification and organizational commitment is needed (e.g., Gautam et al., 2004; Mael \& Tetrick, 1992; O’Reilly \& Chatman, 1986; Riketta, 2005), particularly because organizational identification has been conceptualized as a component of organizational commitment by some researchers (Meyer \& Allen, 1991; Mowday et al., 1979). However, this clear distinction has not been provided by organizational researchers.

Moreover, Miller et al. (2000) argued that because the operationalization of organizational identification has been criticized as measuring organizational commitment instead of identification, they developed the shortened OIQ, which focuses on distinct 
characteristics of organizational identification (i.e., decision-making, embodiment of organizational values) more narrowly than the original OIQ (Cheney, 1983a). However, although the shortened OIQ does resemble organizational identification more closely than the original OIQ, Miller et al. cautioned that the shortened OIQ may still overlap with the organizational commitment construct, as the shortened OIQ contains items that resemble items on scales measuring organizational commitment. As noted on page 48, a high correlation exists between organizational identification and organizational commitment $(r$ $=.91, p<.001)$, suggesting that these two constructs are similar conceptually.

Second, upon reflection, the simple mediation analyses used in this dissertation provide a rather simplistic view of the relationships between superiors' mentoring functions and subordinates' organizational identification and workplace outcomes. As simple mediation model analysis only provides evidence for how one variable directly or indirectly influences another, moderation analysis could provide additional insight regarding the conditions in which this causal relationship exists (Hayes, 2013). That is, although the results of simple mediation model analyses provide one potential explanation for how mentoring functions influence job satisfaction, communication satisfaction, and organizational commitment, moderation analysis could demonstrate when superiors' mentoring functions will have the greatest effect on subordinates' workplace outcomes. For instance, it may be that mentoring functions are more effective at increasing subordinates' organizational identification, job satisfaction, communication satisfaction, and organizational commitment when subordinates have recently joined the organization, as organizational newcomers desire and seek information relevant to navigating their roles within their organization (Jablin, 2001; Miller \& Jablin, 1991). 
Furthermore, although simple mediation model analyses test whether a causal relationship exists, the nature of one-shot survey data--which was employed in this dissertation--does not provide temporal ordering of study variables (Hayes, 2013). Hayes argued that causal claims can still be built from survey data using argument or theory to demonstrate temporal ordering. Temporally, superiors engaging in mentoring functions could logically cause a change in subordinates' organizational identification, and superiors' behaviors are suggested to impact subordinates' attitudes and experiences within the workplace. Although this suggests mediation analysis is appropriate for the data, Hayes also suggested that results of mediation analysis conducted using survey data be considered carefully, as temporal order cannot be ensured. Therefore, one caveat to the results obtained in this dissertation is that, as the temporal ordering of mentoring functions, organizational identification, and job satisfaction, communication satisfaction, and organizational commitment cannot be definitively proven from the data, causal claims should be made with caution.

A third limitation is that although participants reported on the perceived mentoring functions provided by their superiors, participants were never asked whether they actually had a mentor-protégé relationship with the superior on whom they reported. It was assumed that superiors who serve the career development and psychosocial mentoring functions to subordinates also act as mentors. As such, regardless of whether superiors provide subordinates with mentoring, these relationships cannot be considered mentor-protégé relationships, because this question was not asked of participants. Furthermore, as the provision of mentoring fluctuates throughout the course of the mentor-protégé relationship (Kram, 1988), the effect of mentoring functions on 
organizational identification, job satisfaction, communication satisfaction, and organizational commitment over time undoubtedly fluctuates as well. As this dissertation did not examine mentor-protégé relationships specifically, the results of this dissertation are limited in its application to the mentor-protégé relationship between superiors and subordinates. Additionally, within the workplace, individuals other than superiors (e.g., peer coworkers; Kram \& Isabella, 1985) can provide mentoring. Therefore, the results of this dissertation are also limited in that the data only examine one potential source of mentoring functions (i.e., superiors).

Fourth, the self-report nature of the data may contribute to a common method bias. That is, the data may have been affected by the way in which the variables were measured (Podsakoff, MacKenzie, Lee, \& Podsakoff, 2003), as relationships between variables may be inflated as they were reported on by the same source (i.e., each participant reported on each variable; Conway \& Lance, 2010). Furthermore, as participants were recruited through MTurk, caution should be taken when extending the results to more general populations. Participants recruited through MTurk are typically more highly educated and younger than national samples (Sheehan \& Pittman, 2016). Additionally, as a large portion of the sample consisted of participants working in the United States $(n=212)$, followed by participants working in India $(n=76)$, results may not be generalizable across cultures or extended to other countries.

\section{Directions for Future Research}

The results of this dissertation provide three areas for future organizational communication research. First, future studies could examine both superiors' and subordinates' perspectives of mentoring functions in the workplace to examine the extent 
to which these perspectives match. The data collected in this dissertation represent only subordinates' perceptions of their superiors' employment of mentoring functions. However, as superiors' and subordinates' perceptions of superiors' behaviors are not always congruent (Erben, Schneider, \& Maier, 2016; Schnake et al., 1990), superiors who perceive that they are engaging in a specific behavior may have subordinates who do not share this perception. For example, there is evidence that disagreement in superiors' and subordinates' perceptions of the quality of superiors' communication (e.g., openness of communication) is associated with decreased job satisfaction among subordinates (Erben et al.). By examining superiors' reported use of mentoring functions, future researchers may determine whether superiors' perceptions of their provision of mentoring functions matches subordinates' perceptions of receiving these functions, as well as to the extent to which this perceptual congruence increases subordinates' organizational identification, job satisfaction, communication satisfaction, and organizational commitment.

Second, as the results of this dissertation suggest that the provision of mentoring functions from superiors is advantageous for subordinates (i.e., increased job satisfaction, communication satisfaction, and organizational commitment), future research should investigate whether subordinates' use of relational maintenance behaviors is linked with mentoring from their superiors. Previous research demonstrates that subordinates engage in strategies to initiate, develop, and maintain mentor-protégé relationships (Kalbfleisch, 2002; Tepper, 1995) and employ specific relational maintenance behaviors to keep their superiors' relationship in a desired state (Lee, 1998b; Lee \& Jablin, 1995). Lee and Jablin (1995) found that in situations in which subordinates desire a closer relationship than they currently have with their superiors, they use five relational maintenance behaviors: 
engage in direct and open communication (i.e., communicating directly with superiors regarding desires for the relationship), create closeness (i.e., engaging in informal and personal interactions with superiors), employ deception and distortion (i.e., disclosing false information to or withholding information from superiors), offer circumspectiveness (i.e., protecting superiors' self-image), and use self-promotion (i.e., demonstrating competencies to superiors). Furthermore, subordinates perceive their use these five maintenance behaviors, but specifically the creating closeness behavior, as relatively effective in enhancing the quality of their superior-subordinate relationship (Lee, 1998a). Similarly, Waldron (1991) identified four relational maintenance behaviors subordinates employ to maintain the superior-subordinate relationship: personal (i.e., informal communication), contractual (i.e., behaviors conforming to organizational roles), regulative (i.e., impression management), and direct (i.e., explicit conversation regarding the relationship). As subordinates engage in these behaviors to develop or maintain superior-subordinate relationships in a desired state, perhaps subordinates who use relational maintenance behaviors also receive mentoring from their superiors.

Third, future research should address how effective superiors' provision of mentoring functions is in assisting subordinates with navigating their negative workplace experiences. Alternatively, this dissertation focused on positive workplace experiences (i.e., organizational identification, job satisfaction, communication satisfaction, organizational commitment), it also is useful to consider how the provision of mentoring functions alleviates distress associated with negative working conditions (e.g., job demands, destructive workplace relationships, workplace incivility). For example, previous research suggests that job demands (i.e., the physical or psychological effort 
requirements of the job) are mitigated by specific job resources (i.e., characteristics of the job that enable individuals to reduce job demands, achieve goals, or experience growth and development; Bakker \& Demerouti, 2007; Demerouti Bakker, Nachreiner, \& Schaufeli, 2001), in that the combination of high job demands and high job resources is associated with increased employee engagement and organizational commitment (Bakker, Hakanen, Demerouti, \& Xanthopoulou, 2007; Bakker, van Veldhoven, \& Xanthopoulou, 2010). Additionally, the provision of mentoring is associated with increased perceptions of job resources, particularly among employees who place value in work (Chen, Wen, \& Hu, 2017). As mentoring functions from superiors equip subordinates with resources useful in their career development and psychosocial enhancement, perhaps these functions also enable subordinates to become more resilient to negative working conditions.

\section{Conclusion}

This dissertation investigated the relationships between superiors' provision of mentoring and subordinates' organizational identification, job satisfaction, communication satisfaction, and organizational commitment. Through subordinates' reports of their superiors' provision of mentoring and their workplace outcomes, the results of this dissertation provide evidence that superiors' mentoring enhances subordinates' workplace experiences by increasing their organizational identification. That is, superiors who engage in behaviors to serve the career development and psychosocial mentoring functions (i.e., sponsorship, exposure and visibility, coaching, protections, challenging assignments, role modeling, acceptance and confirmation, counseling, and friendship) may actively contribute to how subordinates base their sense 
of self on their organizational membership and their positive affect toward the organization. By providing mentoring to subordinates, superiors can contribute to increased organizational identification among subordinates and can promote an environment in which those subordinates are satisfied with their jobs, satisfied with their communication with their superiors, and committed to their organization. For organizational researchers and practitioners, this dissertation suggests that fostering workplace environments wherein superior-subordinate relationships serve these mentoring functions to subordinates benefits employees and the organization as a whole. 
Notes

1. Articles published within the last ten years (i.e., 2007 to 2017) in Management Communication Quarterly, as well as recent research published by quantitative organizational communication scholars (e.g., Rebecca M. Chory, Jeffrey W. Kassing, Paul E. Madlock, and Catherine Y. K. Westerman), were recorded to identify the most frequently studied outcome variables in published organizational communication research studies. In each study, the variables that served as dependent variables were recorded and counted for frequency of use. The most frequently studied dependent variables were job satisfaction, communication satisfaction, and organizational commitment, which is why they were selected for inclusion in this dissertation.

2. A total of 475 individuals initially participated in this study. However, 175 participants either did not meet data quality standards ( $n=155$; i.e., did not answer filler questions correctly) or did not verify their student enrollment status $(n=20)$ and were not included in the analyses, leaving a sample size of 300.

3. Two of the filler items (i.e., "The earth has three moons," "Please select Strongly Agree") were taken from Sheehan and Pittman (2016). The other filler items (i.e., "A kangaroo is a whale," "I do not understand a word of English") were created for this dissertation. 


\section{References}

Agarwal, V., \& Buzzanell, P. M. (2015). Communicative reconstruction of resilience labor: Identify/identification in disaster-relief workers. Journal of Applied Communication Research, 43, 408-428. doi:10.1080/00909882.2015.1083602

Allen, M. W. (1992). Communication and organizational commitment: Perceived organizational support as a mediating factor. Communication Quarterly, 40, 357367. doi:10.1080/01463379209369852

Allen, N. J., \& Meyer, J. P. (1990). The measurement and antecedents of affective, continuance and normative commitment to the organization. Journal of Occupational Psychology, 63, 1-18. doi:10.1111/j.2044-8325.1990.tb00506.x

Allen, T. D., Eby, L. T., Poteet, M. L., Lentz, E., \& Lima, L. (2004). Career benefits associated with mentoring for protégés: A meta-analysis. Journal of Applied Psychology, 89, 127-136. doi:10.1037/0021-9010.89.1.127

Allen, T. D., McManus, S. E., \& Russell, J. E. A. (1999). Newcomer socialization and stress: Formal peer relationships as a source of support. Journal of Vocational Behavior, 54, 453-470. doi:10.1006/jvbe.1998.1674

Apker, J., Propp, K. M., \& Ford, W. S. Z. (2009). Investigating the effect of nurse-team communication on nurse turnover: Relationships among communication processes, identification, and intent to leave. Health Communication, 24, 106-114. doi:10.1080/10410230802676508

Arnold, K. A., Turner, N., Barling, J., Kelloway, E. K., \& McKee, M. C. (2007). Transformational leadership and psychological well-being: The mediating role of meaningful work. Journal of Occupational Health Psychology, 3, 193-203. 
doi:10.1037/1076-8998.12.3.193

Aryee, S., \& Chay, Y. W. (1994). An examination of the impact of career-oriented mentoring on work commitment attitudes and career satisfaction among professional and managerial employees. British Journal of Management, 5, 241249. doi:10.1111/j.1467-8551.1994.tb00076.x

Ashforth, B. E., \& Mael, F. (1989). Social identity theory and the organization. Academy of Management Review, 14, 20-39. doi:10.5465/AMR.1989.4278999

Askay, D. A., \& Gossett, L. (2015). Concealing communities within the crowd: Hiding organizational identities and brokering member identifications of the Yelp Elite Squad. Management Communication Quarterly, 29, 616-641. doi:10.1177/0893318915597301

Bahniuk, M. H., Dobos, J., \& Hill, S. E. K. (1990). The impact of mentoring, collegial support, and information adequacy on career success: A replication. Journal of Social Behavior and Personality, 5, 431-451.

Baird, J. E., \& Bradley, P. H. (1978). Communication correlates of employee morale. The Journal of Business Communication, 15, 47-56. doi:10.1177/002194367801500306

Bakker, A. B., \& Demerouti, E. (2007). The job demands-resources model: State of the art. Journal of Managerial Psychology, 22, 309-328. doi:10.1108/02683940710733115

Bakker, A. B., Hakanen, J. J., Demerouti, E., \& Xanthopoulou, D. (2007). Job resources boost work engagement, particularly when job demands are high. Journal of Educational Psychology, 99, 274-284. doi:10.1037/0022-0663.99.2.274 
Bakker, A. B., van Veldhoven, M., \& Xanthopoulou, D. (2010). Beyond the demandcontrol model: Thriving on high job demands and resources. Journal of Personnel Psychology, 9, 3-16. doi:10.1027/1866-5888/a000006

Barker, J. R., \& Tompkins, P. K. (1994). Identification in the self-managing organization: Characteristics of target and tenure. Human Communication Research, 21, 223240. doi:10.1111/j.1468-2958.1994.tb00346.x

Baugh, S. G., \& Fagenson-Eland, E. A. (2007). Formal mentoring programs: A "poor cousin" to informal relationships? In B. R. Ragins \& K. E. Kram (Eds.), The handbook of mentoring at work: Theory, research, and practice (pp. 249-272). Los Angeles, CA: Sage.

Baumeister, R. F., \& Leary, M. R. (1995). The need to belong: Desire for interpersonal attachments as a fundamental human motivation. Psychological Bulletin, 117, 497-529. doi:10.1037/0033-2909.117.3.497

Bhattacharya, C. B., \& Elsbach, K. D. (2002). Us versus them: The roles of organizational identification and disidentification in social marketing initiatives. Journal of Public Policy \& Marketing, 21, 26-36. doi:10.1509/jppm.21.1.26.17608

Bhattacharya, C. B., Rao, H., \& Glynn, M. A. (1995). Understanding the bond of identification: An investigation of its correlates among art museum members. Journal of Marketing, 59, 46-57. doi:10.2307/1252327

Bhattacharya, C. B., \& Sen, S. (2003). Consumer-company identification: A framework for understanding consumers' relationships with companies. Journal of Marketing, 67, 76-88. doi:10.1509/jmkg.67.2.76.18609 
Bono, J. E., \& Judge, T. A. (2003). Self-concordance at work: Toward understanding the motivational effects of transformational leaders. Academy of Management Journal, 46, 554-571. doi:10.2307/30040649

Brayfield, A. H., \& Rothe, H. F. (1951). An index of job satisfaction. Journal of Applied Psychology, 35, 307-311. doi:10.1037/h0055617

Buhrmester, M., Kwang, T., \& Gosling, S. D. (2011). Amazon's Mechanical Turk: A new source of inexpensive, yet high-quality data? Perspectives on Psychological Science, 6, 3-5. doi:10.1177/1745691610393980

Bullis, C. (1993). Organizational socialization research: Enabling, constraining, and shifting perspectives. Communication Monographs, 60, 10-17. doi:10.1080/03637759309376289

Bullis, C., \& Bach, B. W. (1989a). Are mentor relationships helping organizations? An exploration of developing mentee-mentor-organizational identifications using turning point analysis. Communication Quarterly, 37, 199-213. doi:10.1080/01463378909385540

Bullis, C., \& Bach, B. W. (1989b). Socialization turning points: An examination of change in organizational identification. Western Journal of Speech Communication, 53, 273-293. doi:10.1080/10570318909374307

Bullis, C. A., \& Tompkins, P. K. (1989). The forest ranger revisited: A study of control practices and identification. Communication Monographs, 56, 287-306. doi:10.1080/03637758909390266

Burke, R. J. (1970). Methods of managing superior-subordinate conflict: Their effectiveness and consequences. Canadian Journal of Behavioural Science, 2, 
124-135. doi:10.1037/h0082716

Burke, R., J., \& Wilcox, D. S. (1969). Effects of different patterns and degrees of openness in superior-subordinate communication on subordinate job satisfaction. Academy of Management Journal, 12, 319-326. doi:10.2307/255179

Cappelli, P., \& Keller, J. (2013). Classifying work in the new economy. Academy of Management Review, 38, 575-596. doi:10.5465/amr.2011.0302

Carmeli, A., Atwater, L., \& Levi, A. (2011). How leadership enhances employees' knowledge sharing: The intervening roles of relational and organizational identification. The Journal of Technology Transfer, 36, 257-274. doi:10.1007/s10961-010-9154-y

Carmeli, A., \& Gittell, J. H. (2009). High-quality relationships, psychological safety, and learning from failures in work organizations. Journal of Organizational Behavior, 30, 709-729. doi:10.1002/job.565

Chao, G. T., Walz, P. M., \& Gardner, P. D. (1992). Formal and informal mentorships: A comparison on mentoring functions and contrast with nonmentored counterparts. Personnel Psychology, 45, 619-636. doi:10.1111/j.1744-6570.1992.tb00863.x

Chen, C., Wen, P., \& Hu, C. (2017). Role of formal mentoring in protégés' work-tofamily conflict: A double-edged sword. Journal of Vocational Behavior, 100, 101-110. doi:10.1016/j.jvb.2017.03.004

Cheney, G. (1983a). On the various and changing meanings of organizational membership: A field study of organizational identification. Communication Monographs, 50, 342-362. doi:10.1080/03637758309390174

Cheney, G. (1983b). The rhetoric of identification and the study of organizational 
communication. Quarterly Journal of Speech, 69, 143-158.

doi:10.1080/00335638309383643

Cheney, G., \& Christensen, L. T. (2001). Organizational identity: Linkages between internal and external communication. In F. M. Jablin \& L. L. Putnam (Eds.), The new handbook of organizational communication: Advances in theory, research, and methods (pp. 231-269). Thousand Oaks, CA: Sage.

Cheney, G., Christensen, L. T., \& Dailey, S. L. (2014). Communicating identity and identification in and around organizations. In L. L. Putnam \& D. K. Mumby (Eds.), The Sage handbook of organizational communication: Advances in theory, research, and methods ( ${ }^{\text {rd }}$ ed., pp. 695-719). Los Angeles, CA: Sage.

Cheney, G., \& Tompkins, P. K. (1987). Coming to terms with organizational identification and commitment. Central States Speech Journal, 38, 1-15. doi:10.1080/10510978709368225

Cho, J., Ramgolam, D. I., Schaefer, K. M., \& Sandlin, A. N. (2011). The rate and delay in overload: An investigation of communication overload and channel synchronicity on identification and job satisfaction. Journal of Applied Communication Research, 39, 38-54. doi:10.1080/00909882.2010.536847

Chun, J. U., Sosik, J. J., \& Yun, N. Y. (2012). A longitudinal study of mentor and protégé outcomes in formal mentoring relationships. Journal of Organizational Behavior, 33, 1071-1094. doi:10.1002/job.1781

Conway, J. M., \& Lance, C. E. (2010). What reviewers should expect from authors regarding common method bias in organizational research. Journal of Business Psychology, 25, 325-334. doi:10.1007/s10869-010-9181-6 
Cronbach, L. J. (1951). Coefficient alpha and the internal structure of tests. Psychometrika, 16, 297-334. doi:10.1007/BF02310555

Croucher, S. M., Long, B. L., Meredith, M. J., Oommen, D., \& Steele, E. L. (2009). Factors predicting organizational identification with intercollegiate forensics teams. Communication Education, 58, 74-91. doi:10.1080/03634520802450523

Dansereau, F., Jr., Graen, G., \& Haga, W. J. (1975). A vertical dyad linkage approach to leadership within formal organizations: A longitudinal investigation of the role making process. Organizational Behavior and Human Performance, 13, 46-78. doi:10.1016/0030-5073(75)90005-7

Dansereau, F., \& Markham, S. E. (1987). Superior-subordinate communication: Multiple levels of analysis. In F. M. Jablin, L. L. Putnam, K. H. Roberts, \& L. W. Porter (Eds.), Handbook of organizational communication: An interdisciplinary perspective (pp. 343-388). Newbury Park, CA: Sage.

Demerouti, E., Bakker, A. B., Nachreiner, F., \& Schaufeli, W. B. (2001). The job demands-resources model of burnout. Journal of Applied Psychology, 86, 499512. doi:10.1037//0021-9010.86.3.499

Dilmore, T. C., Rubio, D. M., Cohen, E., Seltzer, D., Switzer, G. E., Bryce, C.,...Kapoor, W. N. (2010). Psychometric properties of the Mentor Role Instrument when used in an academic medicine setting. CTS: Clinical \& Translational Science, 3, 104108. doi:10.1111/j.1752-8062.2010.00196.x

Dollard, M. F., \& Bakker, A. B. (2010). Psychosocial safety climate as a precursor to conducive work environments, psychological health problems, and employee engagement. Journal of Occupational and Organizational Psychology, 83, 579- 
599. doi:10.1348/096317909X470690

Downs, C. W., \& Hazen, M. D. (1977). A factor analytic study of communication satisfaction. Journal of Business Communication, 14, 63-73. doi:10.1177/002194367701400306

Driskill, G., \& Camp, J. W. (2006). Identification strategies for unity: A study of a unity movement among Christian church organizations. Journal of Communication and Religion, 29, 445-483.

Eichorn, K. C., Martin, M. M., Weber, K., \& Knapp, J. (2012). The relationship between approach/avoidance strategies and emotional support in the superior-subordinate relationship. The Florida Communication Journal, 40, 53-64.

Eisenberg, E. M., Monge, P. R., \& Miller, K. I. (1983). Involvement in communication networks as a predictor of organizational commitment. Human Communication Research, 10, 179-201. doi:10.1111/j.1468-2958.1983.tb00010.x

Eisenberger, R., Karagonlar, G., Stinglhamber, F., Neves, P., Becker, T. E., GonzalezMorales, M. G., \& Steiger-Mueller, M. (2010). Leader-member exchange and affective organizational commitment: The contribution of supervisor's organizational embodiment. Journal of Applied Psychology, 95, 1085-1103. doi:10.1037/a0020858

Epitropaki, O., \& Martin, R. (2005). The moderating role of individual differences in the relation between transformational/transactional leadership perceptions and organizational identification. The Leadership Quarterly, 16, 569-589. doi:10.1016/j.leaqua.2005.06.005

Erben, J., Schneider, F. M., \& Maier, M. (2016). In the ear of the beholder: Self-other 
agreement in leadership communication and its relationship with subordinates' job satisfaction. International Journal of Business Communication. Advance online publication. doi:10.1177/2329488416672431

Falcione, R. L. (1974). Credibility: Qualifier of subordinate participation. Journal of Business Communication, 11, 43-54. doi:10.1177/002194367401100307

Fay, M. J., \& Kline, S. L. (2012). The influence of informal communication on organizational identification and commitment in the context of high-intensity telecommuting. Southern Communication Journal, 77, 61-76. doi:10.1080/1041794x.2011.582921

Field, A. (2011). Discovering statistics using SPSS (3rd ed.). Los Angeles, CA: Sage.

Fix, B., \& Sias, P. M. (2006). Person-centered communication, leader-member exchange, and employee job satisfaction. Communication Research Reports, 23, 35-44. doi:10.1080/17464090500535855

Fonner, K. L., \& Roloff, M. E. (2012). Testing the connectivity paradox: Linking teleworkers' communication media use to social presence, stress from interruptions, and organizational identification. Communication Monographs, 79, 205-231. doi:10.1080/03637751.2012.673000

Fowler, J. L., \& O’Gorman, J. G. (2005). Mentoring functions: A contemporary view of the perceptions of mentees and mentors. British Journal of Management, 16, 5157. doi:10.1111/j.1467-8551.2005.00439.x

Frandsen, S. (2012). Organizational image, identification, and cynical distance: Prestigious professionals in a low-prestige organization. Management Communication Quarterly, 26, 351-376. doi:10.1177/0893318912438692 
Frey, L. R., Botan, C. H., \& Kreps, G. L. (2000). Investigating communication: An introduction to research methods ( $2^{\text {nd }}$ ed.). Boston, MA: Allyn and Bacon.

Fritz, M. S., \& MacKinnon, D. P. (2007). Required sample size to detect the mediated effect. Psychological Science, 18, 233-239. doi:10.1111/j.1467-9280.2007.01882.x

Frone, M. R., \& Major, B. (1988). Communication quality and job satisfaction among managerial nurses: The moderating influence of job involvement. Group \& Organization Studies, 13, 332-347. doi:10.1177/105960118801300306

Gaskill, L. R. (1993). A conceptual framework for the development, implementation, and evaluation of formal mentoring programs. Journal of Career Development, 20, 147-160. doi:10.1177/089484539302000205

Gautam, T., Van Dick, R., \& Wagner, U. (2004). Organizational identification and organizational commitment: Distinct aspects of two related concepts. Asian Journal of Social Psychology, 7, 301-315. doi:10.1111/j.1467-839X.2004.00150.x

Geertshuis, S. A., Morrison, R. L., \& Cooper-Thomas, H. D. (2015). It's not what you say, it's the way that you say it: The mediating effect of upward influencing communications on the relationship between leader-member exchange and performance ratings. International Journal of Business Communication, 52, 228245. doi: $10.1177 / 2329488415572784$

Gerstner, C. R., \& Day, D. V. (1997). Meta-analytic review of leader-member exchange theory: Correlates and construct issues. Journal of Applied Psychology, 82, 827844. doi:10.1037/0021-9010.82.6.827

Giddens, A. (1979). Central problems in social theory: Action, structure and 
contradiction in social analysis. Berkeley, CA: University of California Press.

Gilstrap, C. A., \& Smith, S. M. (2016). Identity tensions during an NGO name change: How managers experience an international organization's rebranding effort. International Journal of Strategic Communication, 10, 445-461. doi:10.1080/1553118X.2016.1225302

Gossett, L. M. (2002). Kept at arm's length: Questioning the organizational desirability of member identification. Communication Monographs, 69, 385-404. doi:10.1080/03637750216548

Graen, G., \& Schiemann, W. (1978). Leader-member agreement: A vertical dyad linkage approach. Journal of Applied Psychology, 63, 206-212. doi:10.1037/0021-9010.63.2.206

Graen, G. B., \& Uhl-Bien, M. (1991). The transformation of professionals into selfmanaging and partially self-designing contributors: Toward a theory of leadership-making. Journal of Management Systems, 3, 25-39.

Graen, G. B., \& Uhl-Bien, M. (1995). Relationship-based approach to leadership: Development of leader-member exchange (LMX) theory of leadership over 25 years: Applying a multi-level multi-domain perspective. Leadership Quarterly, 6, 219-247. doi:10.1016/1048-9843(95)90036-5

Griffin, M. A., Patterson, M. G., \& West, M. A. (2001). Job satisfaction and teamwork: The role of supervisor support. Journal of Organizational Behavior, 22, 537-550. doi:10.1002/job.101

Hall, D. T., Schneider, B., \& Nygren, H. T. (1970). Personal factors in organizational identification. Administrative Science Quarterly, 15, 176-190. 
doi:10.2307/2391488

Harter, J. K., Schmidt, F. L., \& Hayes, T. L. (2002). Business-unit-level relationship between employee satisfaction, employee engagement, and business outcomes: A meta-analysis. Journal of Applied Psychology, 87, 268-279. doi:10.1037//0021-9010.87.2.268

Hatfield, J. D., \& Huseman, R. C. (1982). Perceptual congruence about communication as related to satisfaction: Moderating effects of individual characteristics. Academy of Management Journal, 25, 349-358. doi:10.2307/255996

Hayes, A. F. (2013). Introduction to mediation, moderation, and conditional process analysis: A regression-based approach. New York, NY: Guilford Press.

Hecht, M. L. (1978). Toward a conceptualization of communication satisfaction. Quarterly Journal of Speech, 64, 47-62. doi:10.1080/00335637809383411

Higgins, M. C., \& Kram, K. E. (2001). Reconceptualizing mentoring at work: A developmental network perspective. Academy of Management Review, 26, 264288. doi:10.5465/AMR.2001.4378023

Hill, S. E. K., Bahniuk, M. H., \& Dobos, J. (1989). The impact of mentoring and collegial support on faculty success: An analysis of support, behavior, information adequacy, and communication apprehension. Communication Education, 38, 1533. doi:10.1080/03634528909378737

Hill, S. E. K., Bahniuk, M. H., Dobos, J., \& Rouner, D. (1989). Mentoring and other communication support in the academic setting. Group \& Organization Studies, 14, 355-368. doi:10.1177/105960118901400308

Hirak, R., Peng, A. C., Carmeli, A., \& Schaubroeck, J. M. (2012). Linking leader 
inclusiveness to work unit performance: The importance of psychological safety and learning from failures. The Leadership Quarterly, 23, 107-117.

doi:10.1016/j.leaqua.2011.11.009

Hogg, M. A., \& Terry, D. J. (2000). Social identity and self-categorization processes in organizational contexts. The Academy of Management Review, 25, 121-140. doi:10.5465/AMR.2000.2791606

Hu, C., Wang, S., Yang, C. C., Wu, T. Y. (2014). When mentors feel supported: Relationships with mentoring functions and protégés' perceived organizational support. Journal of Organizational Behavior, 35, 22-37. doi:10.1002/job.1851

Infante, D. A., \& Gorden, W. I. (1979). Subordinate and superior perceptions of self and one another: Relations, accuracy, and reciprocity of liking. The Western Journal of Speech Communication, 43, 212-223. doi:10.1080/10570317909373970

Infante, D. A., \& Gorden, W. I. (1991). How employees see the boss: Test of an argumentative and affirming model of supervisors' communicative behavior. Western Journal of Speech Communication, 55, 294-304. doi:10.1080/10570319109374386

Jablin, F. M. (1979). Superior-subordinate communication: The state of the art. Psychological Bulletin, 86, 1201-1222. doi:10.1037/0033-2909.86.6.1201

Jablin, F. M. (2001). Organizational entry, assimilation, and disengagement/exit. In F. M. Jablin \& L. L. Putnam (Eds.), The new handbook of organizational communication: Advances in theory, research, and methods (pp. 732-818). Thousand Oaks, CA: Sage.

Jaworski, B. J., \& Kohli, A. K. (1991). Supervisory feedback: Alternative types and their 
impact on salespeople's performance and satisfaction. Journal of Marketing

Research, 28, 190-201. doi:10.2307/3172807

Jones, C., \& Volpe, E. H. (2010). Organizational identification: Extending our understanding of social identities through social networks. Journal of Organizational Behavior, 32, 413-434. doi:10.1002/job.694

Ju, R., \& Shoham, M. (2017). Multidimensionality of identification: Exploring the local and global experiences of organizational members across Eastern and Western contexts. Western Journal of Communication, 81, 206-224. doi:10.1080/10570314.2016.1235281

Judge, T. A., Bono, J. E., Erez, A., \& Locke, E. A. (2005). Core self-evaluations and job and life satisfaction: The role of self-concordance and goal attainment. Journal of Applied Psychology, 90, 257-268. doi:10.1037/0021-9010.90.2.257

Judge, T. A., Thoresen, C. J., Bono, J. E., \& Patton, G. K. (2001). The job satisfactionjob performance relationship: A qualitative and quantitative review. Psychological Bulletin, 127, 376-407. doi:10.1037//0033-2909.127.3.376

Kalbfleisch, P. J. (2002). Communicating in mentoring relationships: A theory for enactment. Communication Theory, 12, 63-69. doi:10.1111/j.1468-2885.2002.tb00259.x

Kang, M. (2016). Moderating effects of identification on volunteer engagement: An exploratory study of a faith-based charity organization. Journal of Communication Management, 20, 102-117. doi:10.1108/JCOM-08-2014-0051

Kassing, J. W. (2000a). Exploring the relationship between workplace freedom of speech, organizational identification, and employee dissent. Communication Research 
Reports, 17, 387-396. doi:10.1080/08824090009388787

Kassing, J. W. (2000b). Investigating the relationship between superior-subordinate relationship quality and employee dissent. Communication Research Reports, 17, 58-70. doi:10.1080/08824090009388751

Katz, D., \& Kahn, R. L. (1966). The social psychology of organizations. New York, NY: John Wiley \& Sons.

Kaufman, H. (1960/2006). Forest ranger: A study in administrative behavior (Special reprint edition). Washington, DC: Resources for the Future.

Kelly, S., \& Westerman, C. Y. K. (2014). Immediacy as an influence on supervisorsubordinate communication. Communication Research Reports, 31, 252-261. doi:10.1080/08824096.2014.924335

Keyton, J. (2014). Communication, organizational culture, and organizational climate. In B. Schneider \& K. M. Barbera (Eds.), The Oxford handbook of organizational climate and culture (pp. 118-122). New York, NY: Oxford University Press.

Keyton, J. (2011). Communication research: Asking questions, finding answers. ( $3^{\text {rd }}$ ed.) New York, NY: McGraw Hill.

Kim, S. (2002). Participative management and job satisfaction: Lessons for management leadership. Public Administration Review, 62, 231-241. doi:10.1111/0033-3352.00173

Korschun, D., Bhattacharya, C. B., \& Swain, S. D. (2014). Corporate social responsibility, customer orientation, and the job performance of frontline employees. Journal of Marketing, 78, 20-37. doi:10.1509/jm.11.0245

Kram, K. E. (1983). Phases of the mentor relationship. Academy of Management Journal, 
26, 608-625. doi:10.2307/255910

Kram, K. E. (1988). Mentoring at work: Developmental relationships in organizational life. Lanham, MD: University Press of America.

Kram, K. E., \& Isabella, L. A. (1985). Mentoring alternatives: The role of peer relationships in career development. The Academy of Management Journal, 28, 110-132. doi: $10.2307 / 256064$

Kramer, M. W., Meisenbach, R. J., \& Hansen, G. J. (2013). Communication, uncertainty, and volunteer membership. Journal of Applied Communication Research, 41, 1839. doi:10.1080/00909882.2012.750002

Kramer, M. W., \& Miller, V. D. (1999). A response to criticisms of organizational socialization research: In support of contemporary conceptualizations of organizational assimilation. Communication Monographs, 66, 358-367. doi:10.1080/03637759909376485

Krone, K. J. (1991). Effects of leader-member exchange on subordinates' upward influence attempts. Communication Research Reports, 8, 9-18. doi:10.1080/08824099109359870

Kuvaas, B., \& Dysvik, A. (2010). Exploring alternative relationships between perceived investment in employee development, perceived supervisor support and employee outcomes. Human Resources Management Journal, 20, 138-156. doi:10.1111/j.1748-8583.2009.00120.x

Lammers, J. C., Atouba, Y. L., \& Carlson, E. J. (2013). Which identities matter? A mixed-method study of group, organizational, and professional identities and their relationship to burnout. Management Communication Quarterly, 27, 503-536. 
doi:10.1177/0893318913498824

Lamude, K. G., Scudder, J., Simmons, D., \& Torres, P. (2004). Organizational newcomers: Temporary and regular employees, same-sex and mixed-sex superior-subordinate dyads, supervisor influence techniques, subordinates communication satisfaction, and leader-member exchange. Communication Research Reports, 21, 60-67. doi:10.1080/08824090409359967

Lankau, M. J., \& Scandura, T. A. (2001). Mentoring as a forum for personal learning in organizations. In B. R. Ragins \& K. E. Kram (Eds.), The handbook of mentoring at work: Theory, research, and practice (pp. 95-122). Los Angeles, CA: Sage.

Larson, G. S., \& Pepper, G. L. (2011). Organizational identification and the symbolic shaping of information communication technology. Qualitative Research Reports in Communication, 12, 1-9. doi:10.1080/17459435.2011.601519

Lee, C. H., \& Bruvold, N. T. (2003). Creating value for employees: Investment in employee development. International Journal of Human Resource Management, 14, 981-1000. doi:10.1080/0958519032000106173

Lee, J. (1998a). Effective maintenance communication in superior-subordinate relationships. Western Journal of Communication, 62, 181-208. doi:10.1080/10570319809374605

Lee, J. (1998b). Maintenance communication in superior-subordinate relationships: An exploratory investigation of group social context and the "Pelz effect." Southern Communication Journal, 63, 144-157. doi:10.1080/10417949809373085

Lee, J., \& Jablin, F. M. (1995). Maintenance communication in superior-subordinate work relationships. Human Communication Research, 22, 220-257. 
doi:10.1111/j.1468-2958.1995.tb00367.x

Lee, S. M. (1971). An empirical analysis of organizational identification. Academy of Management Journal, 14, 213-226. doi:10.2307/255308

Levinson, H. (1965). Reciprocation: The relationship between man and organization. Administrative Science Quarterly, 9, 370-390. doi:10.1037/11848-002

Loi, R., Chan, K. W., \& Lam, L. W. (2014). Leader-member exchange, organizational identification, and job satisfaction: A social identity perspective. Journal of Occupational and Organizational Psychology, 87, 42-61. doi:10.1111/joop.12028

Lutgen-Sandvik, P., Riforgiate, S., \& Fletcher, C. (2011). Work as a source of positive emotional experiences and the discourses informing positive assessment. Western Journal of Communication, 75, 2-27. doi:10.1080/10570314.2010.536963

Madlock, P. E. (2008). The link between leadership style, communicator competence, and employee satisfaction. Journal of Business Communication, 45, 61-78. doi:10.1177/0021943607309351

Madlock, P. E., \& Chory, R. M. (2014). Socialization as a predictor of employee outcomes. Communication Studies, 65, 56-71. doi:10.1080/10510974.2013.811429

Madlock, P. E., \& Horan, S. M. (2009). Predicted outcome value of organizational commitment. Communication Research Reports, 26, 40-49. doi:10.1080/08824090802637023

Madlock, P. E., \& Kennedy-Lightsey, C. (2010). The effects of supervisors' verbal aggressiveness and mentoring on their subordinates. Journal of Business Communication, 47, 42-62. doi:10.1177/002194609353511 
Mael, F., \& Ashforth, B. E. (1992). Alumni and their alma mater: A partial test of the reformulated model of organizational identification. Journal of Organizational Behavior, 13, 103-123. doi:10.1002/job.4030130202

Mael, F. A., \& Tetrick, L E. (1992). Identifying organizational identification. Education and Psychological Measurement, 52, 813-824.

doi:10.1177/0013164492052004002

Maneerat, N., Hale, C. L., \& Singhal, A. (2005). The communication glue that binds employees to an organization: A study of organizational identification in two Thai organizations. Asian Journal of Communication, 15, 188-214.

doi:10.1080/01292980500118821

McNamee, L. G. (2011). Faith-based organizational communication and its implications for member identity. Journal of Applied Communication Research, 39, 422-440. doi:10.1080/00909882.2011.608697

Meisenbach, R. J., \& Kramer, M. W. (2014). Exploring nested identities: Voluntary membership, social category identity, and identification in a community choir. Management Communication Quarterly, 28, 187-213. doi:10.1177/0893318914524059

Men, L. R., \& Jiang, H. (2016). Cultivating quality employee-organization relationships: The interplay among organizational leadership, culture, and communication. International Journal of Strategic Communication, 10, 462-479. doi:10.1080/1553118X.2016.1226172

Meyer, J. P., \& Allen, N. J. (1991). A three-component conceptualization of organizational commitment. Human Resource Management Review, 1, 61-89. 
doi:10.1016/1053-4822(91)90011-Z

Mikkelson, A. C., Sloan, D., \& Hesse, C. (2017). The expression of dominance and perceptions of supervisor credibility in supervisor/employee relationships. Communication Research Reports. Advance online publication. doi:10.1080/08824096.2017.1340265

Mikkelson, A. C., York, J. A., \& Arritola, J. (2015). Communication competence, leadership behaviors, and employee outcomes in supervisor-employee relationships. Business and Professional Communication Quarterly, 78, 336-354. doi: $10.1177 / 2329490615588542$

Miller, V. D., Allen, M., Casey, M. K., \& Johnson, J. R. (2000). Reconsidering the Organizational Identification Questionnaire. Management Communication Quarterly, 13, 626-658. doi:10.1177/0893318900134003

Miller, V. D., \& Jablin, F. M. (1991). Information seeking during organizational entry: Influences, tactics, and a model of the process. The Academy of Management Review, 16, 92-120. doi:10.5465/AMR.1991.4278997

Morgan, J. M., Reynolds, C. M., Nelson, T. J., Johanningmeier, A. R., Griffin, M., \& Andrade, P. (2004). Tales from the fields: Sources of employee identification in agribusiness. Management Communication Quarterly, 17, 360-395. doi: $10.1177 / 0893318903258169$

Mowday, R. T., Steers, R. M., \& Porter, L. W. (1979). The measurement of organizational commitment. Journal of Vocational Behavior, 14, 224-247. doi:10.1016/0001-8791(79)90072-1

Mueller, B. H., \& Lee, J. (2002). Leader-member exchange and organizational 
communication satisfaction in multiple contexts. Journal of Business

Communication, 39, 220-244. doi:10.1177/002194360203900204

Mullen, E. J. (1998). Vocational and psychosocial mentoring functions: Identifying mentors who serve both. Human Resource Development Quarterly, 9, 319-331. doi:10.1002/hrdq.3920090403

Myers, K. K., Davis, C. W., Schreuder, E. R., \& Seibold, D. R. (2016). Organizational identification: A mixed methods study exploring students' relationship with their university. Communication Quarterly, 64, 210-231.

doi:10.1080/01463373.2015.1103285

Myers, K. K., \& Oetzel, J. G. (2001). Exploring the dimensions of organizational assimilation: Creating and validating a measure. Communication Quarterly, 51, 438-457. doi:10.1080/01463370309370166

Myers, S. A., \& Johnson, A. D. (2004). Perceived solidarity, self-disclosure, and trust in organizational peer relationships. Communication Research Reports, 21, 75-83. doi:10.1080/08824090409359969

Myers, S. A., \& Kassing, J. W. (1998). The relationship between perceived supervisory communication behaviors and subordinate organizational identification.

Communication Research Reports, 15, 71-81. doi:10.1080/08824099809362099

Myers, S. A., Knox, R. L., Pawlowski, D. R., \& Ropog, B. L. (1999). Perceived communication openness and functional communication skills among organizational peers. Communication Reports, 12, 71-83.

doi:10.1080/08934219909367712

Ngo, H. Y., Loi, R., Foley, S., Zheng, X., \& Zhang, L. (2013). Perceptions of 
organizational context and job attitudes: The mediating effect of organizational identification. Asia Pacific Journal of Management, 30, 149-168.

doi:10.1007/s10490-012-9289-5

Noe, R. A. (1988). An investigation of the determinants of successful assigned mentoring relationships. Personnel Psychology, 41, 457-479. doi:10.1111/j.1744-6570.1988.tb00638.x

O’Reilly, III, C., \& Chatman, J. (1986). Organizational commitment and psychological attachment: The effects of compliance, identification, and internalization on prosocial behavior. Journal of Applied Psychology, 71, 492-499. doi:10.1037/0021-9010.71.3.492

Pacanowsky, M. E., \& O’Donnell-Trujillo, N. (1982). Communication and organizational cultures. Western Journal of Speech Communication, 46, 115-130. doi:10.1080/10570318209374072

Paolacci, G., \& Chandler, J. (2014). Inside the Turk: Understanding Mechanical Turk as a participant pool. Current Directions in Psychological Science, 23, 184-188. doi:10.1177/0963721414531598

Patchen, M. (1970). Participation, achievement, and involvement on the job. Englewood Cliffs, NJ: Prentice-Hall.

Pincus, J. D. (1986). Communication satisfaction, job satisfaction, and job performance. Human Communication Research, 12, 395-419. doi:10.1111/j.1468-2958.1986.tb00084.x

Ploeger, N. A., \& Bisel, R. S. (2013). The role of identification in giving sense to unethical organizational behavior: Defending the organization. Management 
Communication Quarterly, 27, 155-183. doi:10.1177/0893318912469770

Podsakoff, P. M., MacKenzie, S. B., Lee, J. Y., \& Podsakoff, N. P. (2003). Common method bias in behavioral research: A critical review of literature and recommended remedies. Journal of Applied Psychology, 88, 879-903. doi:10.1037/0021-9010.88.5.879

Porter, L. W., Steers, R. M., Mowday, R. T., \& Boulian, P. V. (1974). Organizational commitment, job satisfaction, and turnover among psychiatric technicians. Journal of Applied Psychology, 59, 603-609. doi:10.1037/h0037335

Postmes, T., Tanis, M., \& de Wit, B. (2001). Communication and commitment in organizations: A social identity approach. Group Processes \& Intergroup Relations, 4, 227-246. doi:10.1177/1368430201004003004

Putti, J. M., Aryee, S., \& Phua, J. (1990). Communication relationship satisfaction and organizational commitment. Group \& Organization Studies, 15, 44-52. doi:10.1177/105960119001500104

Ragins, B. R., \& Cotton, J. L. (1999). Mentor functions and outcomes: A comparison of men and women in formal and informal mentoring relationships. Journal of Applied Psychology, 84, 529-550. doi:10.1037/0021-9010.84.4.529

Ragins, B. R., \& McFarlin, D. B. (1990). Perceptions of mentor roles in cross-gender mentoring relationships. Journal of Vocational Behavior, 37, 321-339. doi:10.1016/0001-8791(90)90048-7

Rapp, A., Agnihotri, R., Baker, T. L., \& Andzulis, J. M. (2015). Competitive intelligence collection and use by sales and service representatives: How managers' recognition and autonomy moderate individual performance. Journal of the 
Academy of Marketing Science, 43, 357-374. doi:10.1007/s11747-014-0384-7

Reed, K., Goolsby, J. R., \& Johnston, M. K. (2016). Extracting meaning and relevance from work: The potential connection between the listening environment and employee's organizational identification and commitment. International Journal of Business Communication, 53, 326-342. doi:10.1177/2329488414525465

Richmond, V. P., McCroskey, J. C., \& Davis, L. M. (1986). Communication apprehension and affinity-seeking in superior-subordinate relationships. World Communication, 15, 41-54.

Riketta, M. (2005). Organizational identification: A meta-analysis. Journal of Vocational Behavior, 66, 358-384. doi:10.1016/j.jvb.2004.05.005

Roach, K. D. (1998). Management view, power use, and affinity-seeking: Effects on college student employee identification. Communication Research Reports, 15, 354-364. doi:10.1080/08824099809362134

Roberts, K. H., \& O’Reilly, III, C. A. (1974). Failures in upward communication in organizations: Three possible culprits. Academy of Management Journal, 17, 205215. doi: $10.2307 / 254974$

Rosso, B. D., Dekas, K. H., \& Wrzesniewski, A. (2010). On the meaning of work: A theoretical integration and review. Research in Organizational Behavior, 30, 91127. doi:10.1016/j.riob.2010.09.001

Rusbult, C. E., \& Farrell, D. (1983). A longitudinal test of the investment model: The impact on job satisfaction, job commitment, and turnover of variations in rewards, costs, alternatives, and investments. Journal of Applied Psychology, 68, 429-438. doi:10.1037/0021-9010.68.3.429 
Russell, S. S., Spitzmüller, C., Lin, L. F., Stanton, J. M., Smith, P. C., \& Ironson, G. H. (2004). Shorter can also be better: The Abridged Job in General Scale. Educational and Psychological Measurement, 64, 878-893. doi:10.1177/0013164404264841

Scandura, T. A. (1992). Mentorship and career mobility: An empirical investigation. Journal of Organizational Behavior, 13, 169-174. doi:10.1002/job.4030130206

Scandura, T. A., \& Williams, E. A. (2001). An investigation of the moderating effects of gender on the relationships between mentorship initiation and protégé perceptions of mentoring functions. Journal of Vocational Behavior, 59, 342-363. doi:10.1006/jvbe.2001.1809

Schaufeli, W. B., \& Bakker, A. B. (2004). Job demands, job resources, and their relationship with burnout and engagement: A multi-sample study. Journal of Organizational Behavior, 25, 293-315. doi:10.1002/job.248

Schnake, M. E., Dumler, M. P., Cochran, D. S., \& Barnett, T. R. (1990). Effects of differences in superior and subordinate perceptions of superiors' communication practices. The Journal of Business Communication, 27, 37-50.

Schockett, M. R., \& Haring-Hidore, M. (1985). Factor analytic support for psychosocial and vocational mentoring functions. Psychological Reports, 57, 627-630. doi:10.2466/pr0.1985.57.2.627

Schrodt, P. (2002). The relationship between organizational identification and organizational culture: Employee perceptions of culture and identification in a retail sales organization. Communication Studies, 53, 189-202. doi:10.1080/10510970209388584 
Scott, C. R., Corman, S. R., \& Cheney, G. (1998). Development of a stucturational model of identification in the organization. Communication Theory, 8, 298-336. doi:10.1111/j.1468-2885.1998.tb00223.x

Scott, C. R., \& Stephens, K. K. (2009). It depends on who you're talking to...: Predictors and outcomes of situated measures of organizational identification. Western Journal of Communication, 71, 370-394. doi:10.1080/10570310903279075

Sheehan, K. B., \& Pittman, M. (2016). Amazon's Mechanical Turkfor Academics: The HIT Handbook for Social Science Research. Irvine, CA: Melvin \& Leigh.

Sheldon, K. M., \& Elliot, A. J. (1999). Goal striving, need satisfaction, and longitudinal well-being: The self-concordance model. Journal of Personality and Social Psychology, 76, 482-497. doi:10.1037/0022-3514.76.3.482

Shore, L. M., \& Martin, H. J. (1989). Job satisfaction and organizational commitment in relation to work performance and turnover intentions. Human Relations, 42, 625638. doi:10.1177/001872678904200705

Sias, P. M. (2009). Organizing relationships: Traditional and emerging perspectives on workplace relationships. Los Angeles, CA: Sage.

Sias, P. M. (2017). Company Facebook and organizational identification. Communication Research Reports, 34, 335-343. doi: 10.1080/08824096.2017.1350574

Silva, D., \& Sias, P. M. (2010). Connection, restructuring, and buffering: How groups link individuals and organizations. Journal of Applied Communication Research, 38, 145-166. doi:10.1080/00909881003639510

Sollitto, M., Martin, M. M., Dusic, S., Gibbons, K. E., \& Wagenhouser, A. (2016). Assessing the supervisor-subordinate relationship involving part-time employees. 
International Journal of Business Communication, 53, 74-96.

doi: $10.1177 / 2329488414525462$

Sollitto, M., \& Myers, S. A. (2015). Peer coworker relationships: Influences on the expression of lateral dissent. Communication Reports, 28, 36-47.

doi:10.1080/08934215.2014.925569

Sosik, J. J., \& Godshalk, V. M. (2000). Leadership styles, mentoring functions received, and job-related stress: A conceptual model and preliminary study. Journal of Organizational Behavior, 21, 365-390.

doi:10.1002/(SICI)1099-1379(200006)21:4<365::AID-JOB14>3.0.CO;2-H

Steele, G. A., \& Plenty, D. (2015). Supervisor-subordinate communication competence and job and communication satisfaction. International Journal of Business Communication, 52, 294-318. doi:10.1177/2329488414525450

Steger, M. F., Dik, B. J., \& Duffy, R. D. (2012). Measuring meaningful work: The Work and Meaning Inventory (WAMI). Journal of Career Assessment, 20, 322-337. doi: $10.1177 / 1069072711436160$

Stephens, K. K., \& Dailey, S. L. (2012). Situated organizational identification in newcomers: Impacts of preentry organizational exposure. Management Communication Quarterly, 26, 404-422. doi:10.1177/0893318912440179

Stephens, K. K., Goins, E. S., \& Dailey, S. L. (2014). Organizations disseminating health messages: The roles of organizational identification and HITs. Health Communication, 29, 398-409. doi:10.1080/10410236.2012.759896

Stephens, K. K., Pastorek, A., Crook, B., Mackert, M., Donovan, E. E., \& Shalev, H. (2015). Boosting healthy heart employer-sponsored health dissemination efforts: 
Identification and information-sharing intentions. Health Communication, 30, 209-220. doi:10.1080/10410236.2013.836732

Stringer, L. (2006). The link between the quality of the supervisor-employee relationship and the level of the employee's job satisfaction. Public Organization Review, 6, 125-142. doi:10.1007/s11115-006-0005-0

Supeli, A., \& Creed, P. A. (2016). The longitudinal relationship between protean career orientation and job satisfaction, organizational commitment, and intention-to-quit. Journal of Career Development, 43, 66-80. doi:10.1177/0894845315581686

Tajfel, H., \& Turner, J. C. (1986). The social identity theory of intergroup behavior. In S. Worchel \& W. G. Austin (Eds.), Psychology of Intergroup Relations (pp. 7-24). Chicago, IL: Burnham.

Tepper, B. J. (1995). Upward maintenance tactics in supervisory mentoring and nonmentoring relationships. The Academy of Management Journal, 38, 11911205. doi: $10.2307 / 256626$

Tepper, K., Shaffer, B. C., \& Tepper, B. J. (1996). Latent structure of mentoring function scales. Validity Studies, 56, 848-857. doi:10.1177/0013164496056005013

Teven, J. J., McCroskey, J. C., \& Richmond, V. P. (2006). Communication correlates of perceived Machiavellianism of supervisors: Communication orientations and outcomes. Communication Quarterly, 54, 127-142.

doi:10.1080/01463370600650829

Tornes, M., \& Kramer, M. W. (2015). The volunteer experience in temporary organizations: Volunteer role negotiation and identification in a pop-culture convention. Communication Studies, 66, 590-606. 
doi:10.1080/10510974.2015.1073165

Turban, D. B., \& Dougherty, T. W. (1994). Role of protégé personality in receipt of mentoring and career success. Academy of Management Journal, 37, 688-702.

Tziner, A., \& Latham, G. P. (1989). The effects of appraisal instrument, feedback and goal-setting on worker satisfaction and commitment. Journal of Organizational Behavior, 10, 145-153. doi:10.1002/job.4030100205

van Dick, R., Wagner, U., Stellmacher, J., \& Christ, O. (2004). The utility of a broader conceptualization of organizational identification: Which aspects really matter? Journal of Occupational Psychology, 77, 171-191. doi:10.1348/096317904774202135

van Knippenberg, D., \& Sleebos, E. (2006). Organizational identification versus organizational commitment: Self-definition, social exchange, and job attitudes. Journal of Organizational Behavior, 27, 571-584. doi:10.1002/job.359 van Knippenberg, D., \& van Schie, E. C. M. (2000). Foci and correlates of organizational identification. Journal of Occupational and Organizational Psychology, 73, 137147. doi:10.1348/096317900166949

van Maanen, J. (1978). People processing: Strategies of organizational socialization. Organizational Dynamics, 7, 19-36. doi:10.1016/0090-2616(78)90032-3

Varona, F. (1996). Relationship between communication satisfaction and organizational commitment in three Guatemalan organizations. Journal of Business Communication, 33, 11-140. doi:10.1177/002194369603300203

Veksler, A. E., \& Boren, J. P. (2017). Communicatively restricted organizational stress (CROS) II: Development and validation of the CROS-14. Communication 
Methods and Measures, 11, 137-149. doi:10.1080/19312458.2017.1299120

Waldeck, J. H., Orrego, V. O., Plax, T. G., \& Kearney, P. (1997). Graduate student/faculty mentoring relationships: Who gets mentored, how it happens, and to what end. Communication Quarterly, 45, 93-109. doi:10.1080/01463379709370054

Waldron, V. R. (1991). Achieving communication goals in superior-subordinate relationships: The multi-functionality of upward maintenance tactics. Communication Monographs, 58, 289-306. doi:10.1080/03637759109376231

Walumbwa, F. O., Mayer, D. M., Wang, P., Wang, H., Workman, K., \& Christensen, A. L. (2011). Linking ethical leadership to employee performance: The roles of leader-member exchange, self-efficacy, and organizational identification. Organizational Behavior and Human Decision Processes, 115, 204-213. doi:10.1016/j.obhdp.2010.11.002

Wayne, S. J., Shore, L. M., \& Liden, R. C. (1997). Perceived organizational support and leader-member exchange: A social exchange perspective. The Academy of Management Journal, 40, 82-111. doi:10.2307/257021

Wheeless, L. R., Wheeless, V. E., \& Howard, R. D. (1984). The relationships of communication with supervisor and decision-participation to employee job satisfaction. Communication Quarterly, 32, 222-232. doi:10.1080/01463378409369555

Wheeless, V. E., Wheeless, L. R., \& Howard, R. D. (1983). An analysis of the contribution of participative decision making and communication with supervisor as predictors of job satisfaction. Research in Higher Education, 18, 145-160. 
doi:10.1007/BF00992059

Wiesenfeld, B. M., Raghuram, S., \& Garud, R. (2001). Organizational identification among virtual workers: The role of need for affiliation and perceived work-based social support. Journal of Management, 27, 213-229. doi:10.1177/014920630102700205

Williams, E. A., \& Connaughton, S. L. (2012). Expressions of identifications: The nature of talk and identity tensions among organizational members in a struggling organization. Communication Studies, 63, 457-481.

doi:10.1080/10510974.2011.630439 


\section{Appendix A}

MTurk Advertisement

Researchers at West Virginia University are conducting academic research on the mentoring individuals receive from their direct supervisor and their workplace experiences. The survey will take approximately 20 minutes to complete. Anyone can participate who is at least 18 years old, who is employed full-time (i.e., work at least 35 hours a week), who reports to a direct supervisor, and who is not enrolled in college on a full- or part-time bases. IRB approval is on file for this study. Select the link below to complete the survey. When you have finished the survey, please enter the code provided at the end of the survey in the box below to receive 50 cents payment. After it's confirmed that you participated in the survey, your payment will be transferred to your MTurk account. Thank you. 
Appendix B

Cover Letter

July 2017

Dear Participant:

We are conducting a research study examining superior-subordinate relationships and mentoring. This project is being conducted by Principal Investigator Dr. Scott A. Myers and Co-Investigator Molly Eickholt in the Department of Communication Studies at West Virginia University. This questionnaire will take approximately 20 minutes to complete. Your participation is greatly appreciated.

To participate in this study, you must be at least 18 years of age, be employed full-time (i.e., work at least 35 hours per week), report to a direct supervisor, and not be enrolled as a college student on a part- or full-time basis. Your involvement in this project will be kept anonymous. Please complete the questionnaire independently, and be sure to read the instructions carefully and answer honestly. There are no right or wrong answers. Participation in this study is completely voluntary. You may skip certain questions if you want, and you may stop completing the questionnaire at any time without fear of penalty. There are no known risks associated with participation in this study. Completing this questionnaire indicates that you have agreed to participate in this study. Upon completion of the survey, you will be compensated $\$ 0.50$ for your participation.

If you would like more information about this research project, feel free to contact CoInvestigator Molly Eickholt at mseickholt@mix.wvu.edu. This study has been acknowledged by West Virginia University's Institutional Review Board and is on file as Protocol \#1706617386.

If you would like to participate, please continue to the next page.

Thank you for your participation.

Sincerely,

Dr. Scott A. Myers

Professor

Principal Investigator

scott.myers@mail.wvu.edu
Molly S. Eickholt, M.A.

Ph.D. Candidate

Co-Investigator

mseickholt@mix.wvu.edu 


\section{Appendix C}

\section{Qualtrics Survey}

July 2017

Dear Participant:

We are conducting a research study examining superior-subordinate relationships and mentoring. This project is being conducted by Principal Investigator Dr. Scott A. Myers and CoInvestigator Molly Eickholt in the Department of Communication Studies at West Virginia University. This questionnaire will take approximately 20 minutes to complete. Your participation is greatly appreciated.

To participate in this study, you must be at least 18 years of age, be employed full-time (i.e., work at least 35 hours per week), report to a direct supervisor, and not be enrolled as a college student on a part- or full-time basis. Your involvement in this project will be kept anonymous. Please complete the questionnaire independently, and be sure to read the instructions carefully and answer honestly. There are no right or wrong answers. Participation in this study is completely voluntary. You may skip certain questions if you want, and you may stop completing the questionnaire at any time without fear of penalty. There are no known risks associated with participation in this study. Completing this questionnaire indicates that you have agreed to participate in this study. Upon completion of the survey, you will be compensated $\$ 0.50$ for your participation.

If you would like more information about this research project, feel free to contact CoInvestigator Molly Eickholt at mseickholt@mix.wvu.edu. This study has been acknowledged by West Virginia University's Institutional Review Board and is on file as Protocol \#1706617386.

If you would like to participate, please continue to the next page.

Thank you for your participation.

Sincerely,

Dr. Scott A. Myers

Professor

Principal Investigator

scott.myers@mail.wvu.edu
Molly S. Eickholt, M.A.

Ph.D. Candidate

Co-Investigator

mseickholt@mix.wvu.edu 
We are interested in examining the communication between you and your direct supervisor. Your direct supervisor is someone to whom you report who has the formal authority to direct and evaluate your performance within your organization. Please think of this person when responding to the following questions.

The following statements describe behaviors your direct supervisor may employ. Please indicate the extent of your agreement or disagreement with each statement.

My direct supervisor...

\begin{tabular}{|c|c|c|c|c|c|c|c|}
\hline & $\begin{array}{l}\text { Strongly } \\
\text { disagree }\end{array}$ & Disagree & $\begin{array}{l}\text { Somewhat } \\
\text { disagree }\end{array}$ & $\begin{array}{l}\text { Neither } \\
\text { agree } \\
\text { nor } \\
\text { disagree }\end{array}$ & $\begin{array}{l}\text { Somewhat } \\
\text { agree }\end{array}$ & Agree & $\begin{array}{c}\text { Strongly } \\
\text { agree }\end{array}$ \\
\hline $\begin{array}{l}\text { helps me attain } \\
\text { desirable } \\
\text { positions. } \\
\text { uses his/her }\end{array}$ & O & $\mathrm{O}$ & O & $\mathrm{O}$ & O & $\mathrm{O}$ & $\mathrm{O}$ \\
\hline $\begin{array}{l}\text { uses his/her } \\
\text { influence in the } \\
\text { organization for } \\
\text { my benefit. }\end{array}$ & $\mathrm{O}$ & $\mathrm{O}$ & $\mathrm{O}$ & 0 & $\mathrm{O}$ & $\mathrm{O}$ & O \\
\hline $\begin{array}{l}\text { uses his/her } \\
\text { influence to } \\
\text { support my } \\
\text { advancement in } \\
\text { the organization. }\end{array}$ & $\mathrm{O}$ & $\mathrm{O}$ & $\mathrm{O}$ & $\mathrm{O}$ & O & O & O \\
\hline $\begin{array}{l}\text { suggests specific } \\
\text { strategies for } \\
\text { achieving career } \\
\text { aspirations. }\end{array}$ & $\mathrm{O}$ & $\mathrm{O}$ & $\mathrm{O}$ & 0 & $\mathrm{O}$ & 0 & $\mathrm{O}$ \\
\hline $\begin{array}{l}\text { gives me advice } \\
\text { on how to attain } \\
\text { recognition in } \\
\text { the organization. }\end{array}$ & $\mathrm{O}$ & $\mathrm{O}$ & O & $\mathrm{O}$ & $\mathrm{O}$ & O & 0 \\
\hline $\begin{array}{l}\text { helps me learn } \\
\text { about other } \\
\text { parts of the } \\
\text { organization. }\end{array}$ & $\mathrm{O}$ & $\mathrm{O}$ & $\mathrm{O}$ & $\mathrm{O}$ & O & $\mathrm{O}$ & O \\
\hline $\begin{array}{l}\text { "runs } \\
\text { interference" for } \\
\text { me in the } \\
\text { organization. }\end{array}$ & $\mathrm{O}$ & $\mathrm{O}$ & $\mathrm{O}$ & O & $\mathrm{O}$ & O & 0 \\
\hline $\begin{array}{l}\text { shields me from } \\
\text { damaging } \\
\text { contact with } \\
\text { important } \\
\text { people in the } \\
\text { organization. }\end{array}$ & $\mathrm{O}$ & $\mathrm{O}$ & O & O & O & $\mathrm{O}$ & 0 \\
\hline protects me & $\mathrm{O}$ & $\mathrm{O}$ & $\mathrm{O}$ & $\mathrm{O}$ & $\mathrm{O}$ & $\mathrm{O}$ & 0 \\
\hline
\end{tabular}




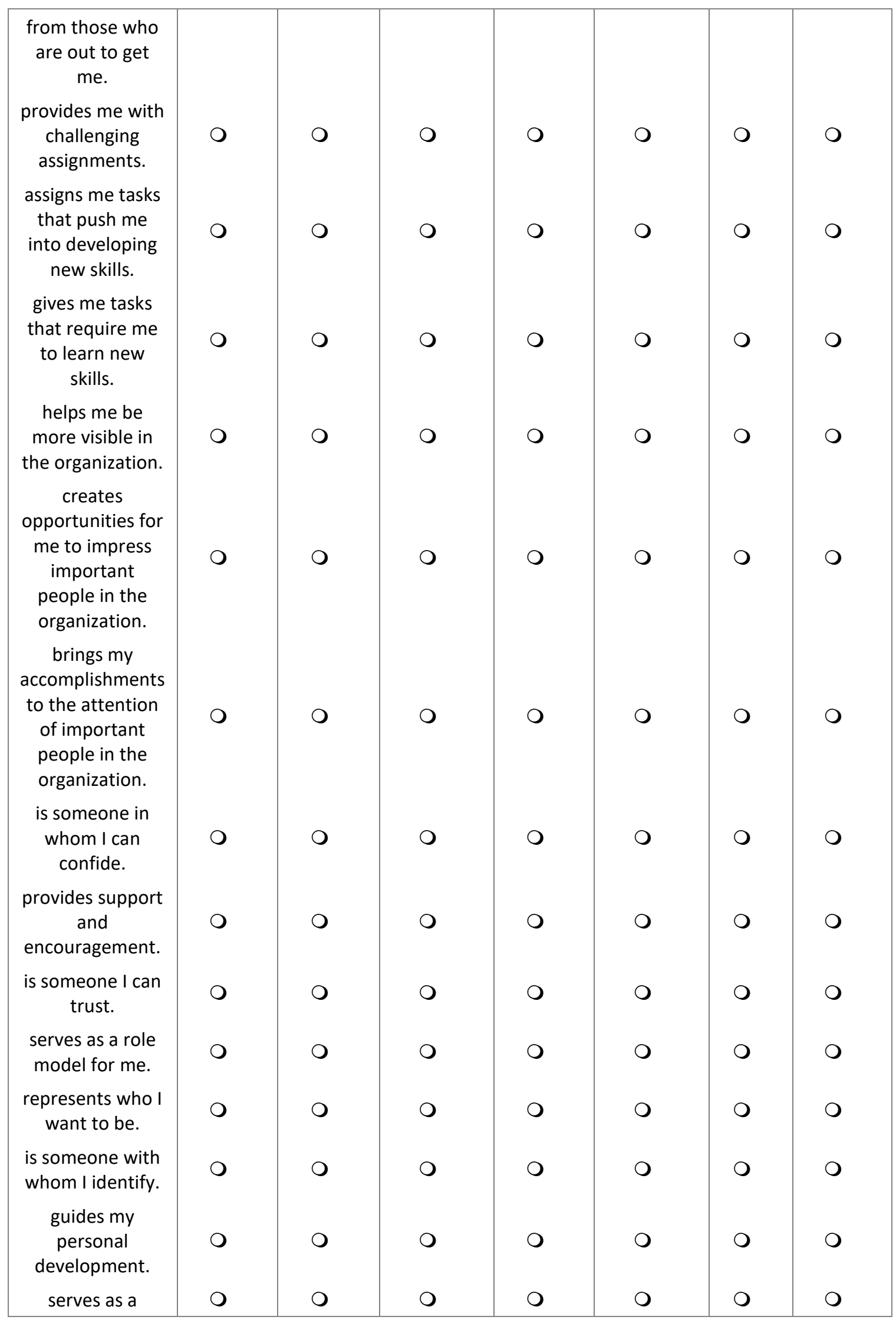




\begin{tabular}{|c|c|c|c|c|c|c|c|}
\hline $\begin{array}{c}\text { sounding board } \\
\text { for me to } \\
\text { develop and } \\
\text { understand } \\
\text { myself. }\end{array}$ & 0 & 0 & 0 & 0 & 0 & 0 & 0 \\
$\begin{array}{c}\text { guides my } \\
\text { professional } \\
\text { development. }\end{array}$ & 0 & 0 & 0 & 0 & 0 & 0 & 0 \\
$\begin{array}{c}\text { accepts me as a } \\
\text { competent } \\
\text { professional. }\end{array}$ & 0 & 0 & 0 & 0 & 0 & 0 & 0 \\
$\begin{array}{c}\text { thinks highly of } \\
\text { me. }\end{array}$ & 0 & 0 & 0 & 0 & 0 & 0 \\
$\begin{array}{c}\text { sees me as being } \\
\text { competent. }\end{array}$ & 0 & 0 & 0 & 0 & 0 & 0 \\
\hline $\begin{array}{c}\text { please select } \\
\text { strongly Agree. }\end{array}$ & 0 & 0 & 0 & 0 & \\
\hline
\end{tabular}

Listed below are several statements that describe possible feelings about interactions with the direct supervisor on which you reported above. Your direct supervisor is someone to whom you report who has the formal authority to direct and evaluate your performance within your organization. Please think of this person when responding to the following questions.

Keeping in mind your interactions with your direct supervisor in general, please indicate the extent of your agreement or disagreement with each statement.

When communicating with my direct supervisor I feel...

\begin{tabular}{|c|c|c|c|c|c|c|c|}
\hline & $\begin{array}{c}\text { Strongly } \\
\text { disagree }\end{array}$ & Disagree & $\begin{array}{c}\text { Somewhat } \\
\text { disagree }\end{array}$ & $\begin{array}{c}\text { Neither } \\
\text { agree } \\
\text { nor } \\
\text { disagree }\end{array}$ & $\begin{array}{c}\text { Somewhat } \\
\text { agree }\end{array}$ & Agree & $\begin{array}{c}\text { Strongly } \\
\text { agree }\end{array}$ \\
\hline $\begin{array}{c}\text { he or she lets } \\
\text { me know that I } \\
\text { am }\end{array}$ & 0 & 0 & 0 & 0 & 0 & 0 & 0 \\
$\begin{array}{c}\text { communicating } \\
\text { effectively. } \\
\text { nothing is ever } \\
\text { accomplished. } \\
\text { he or she } \\
\text { listens and } \\
\text { pays attention } \\
\text { to me. }\end{array}$ & 0 & 0 & 0 & 0 & 0 & 0 & 0 \\
$\begin{array}{c}\text { I would like to } \\
\text { continue } \\
\text { having }\end{array}$ & 0 & 0 & 0 & 0 & 0 & 0 & 0 \\
\hline \begin{tabular}{c} 
conversations \\
\hline
\end{tabular} & 0 & 0 & 0 & 0 & 0 \\
\hline
\end{tabular}




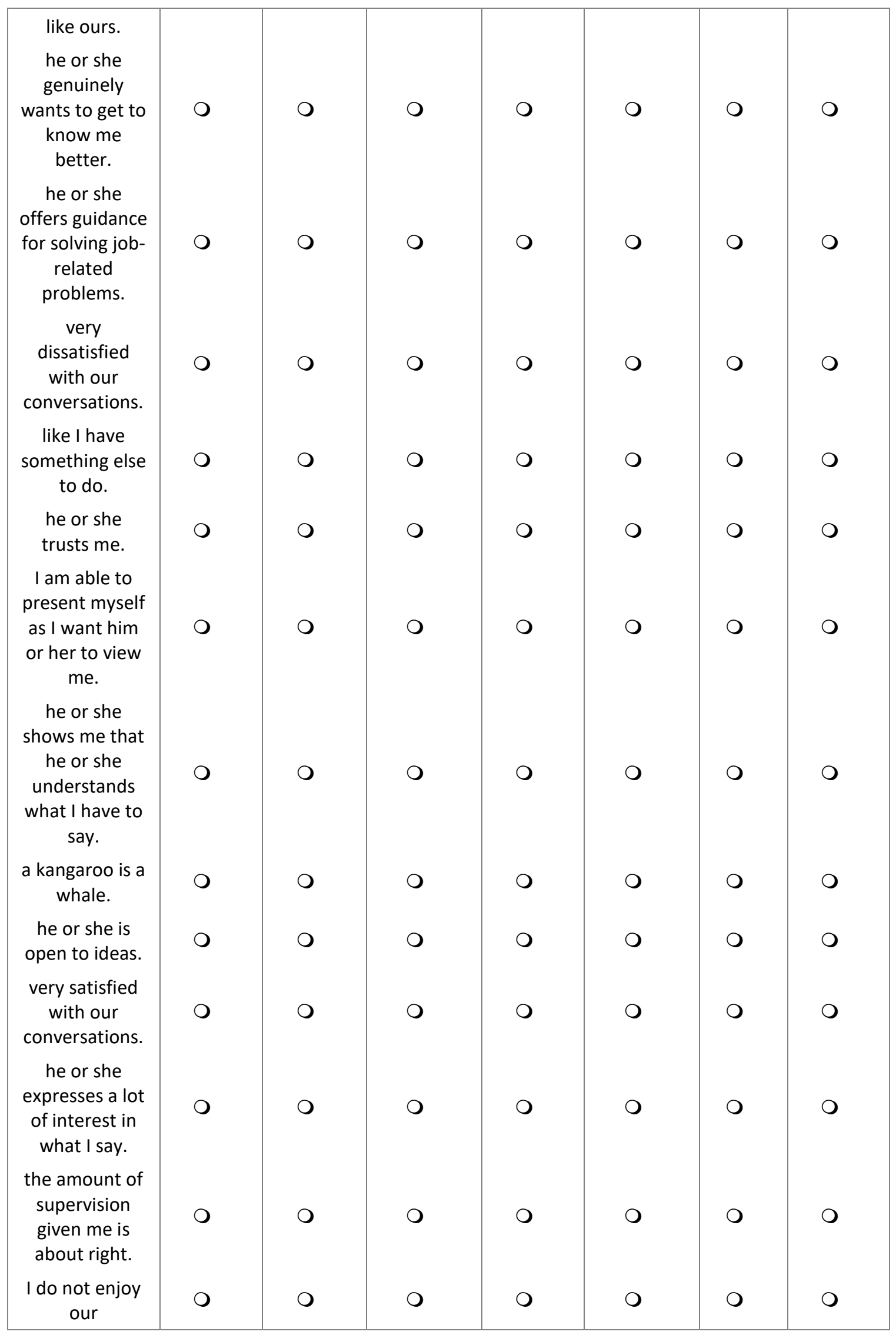




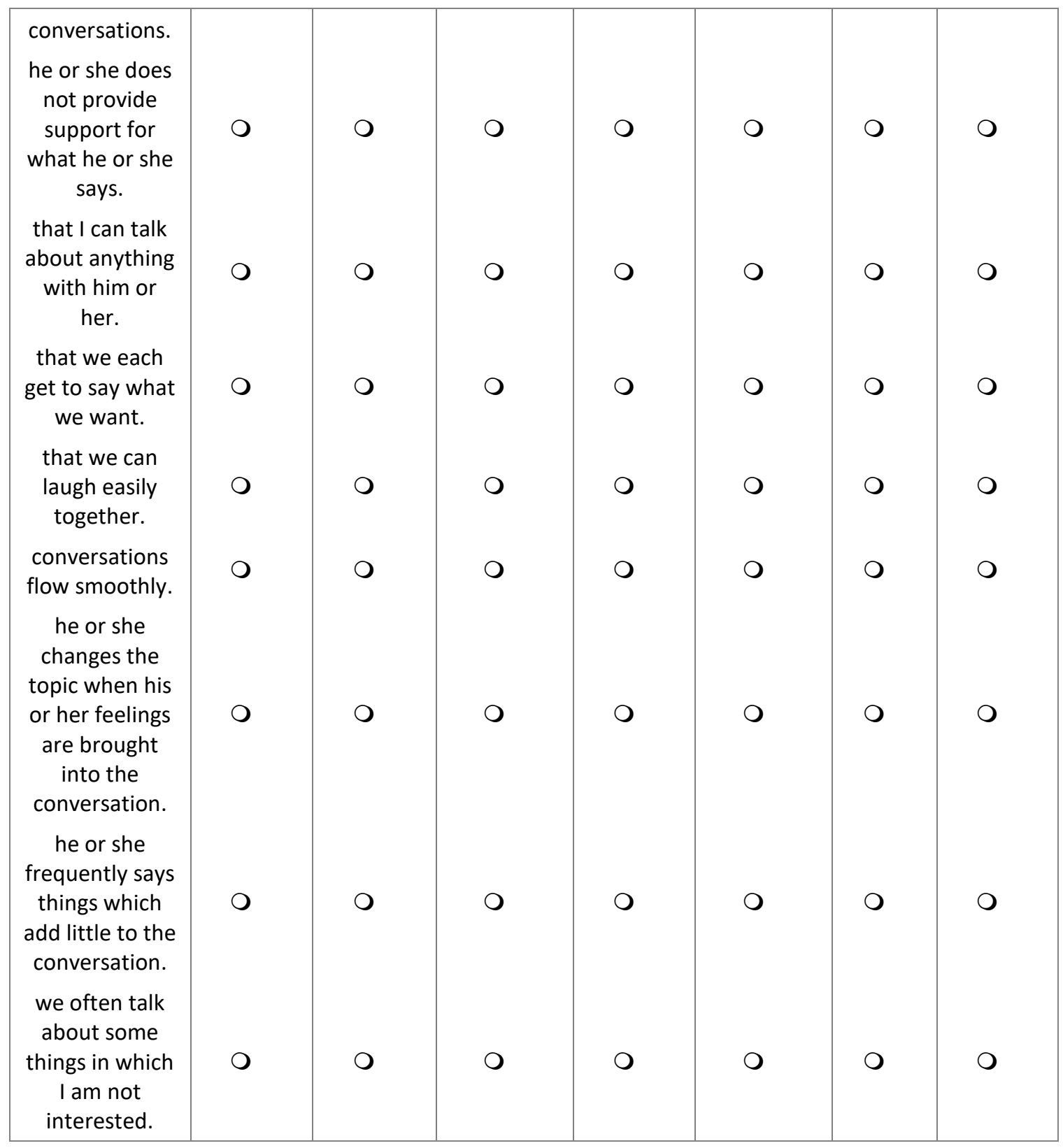

Listed below is a series of statements that represent possible feelings that individuals might have about their organization. With respect to your own feelings about the organization at which you are currently employed, please indicate the extent of your agreement or disagreement with each of the following statements.

\begin{tabular}{|l|c|c|c|c|c|c|c|}
\hline & $\begin{array}{c}\text { Strongly } \\
\text { disagree }\end{array}$ & Disagree & $\begin{array}{c}\text { Somewhat } \\
\text { disagree }\end{array}$ & $\begin{array}{c}\text { Neither } \\
\text { agree nor } \\
\text { disagree }\end{array}$ & $\begin{array}{c}\text { Somewhat } \\
\text { agree }\end{array}$ & Agree & $\begin{array}{c}\text { Strongly } \\
\text { agree }\end{array}$ \\
\hline $\begin{array}{c}\text { I am proud to } \\
\text { be an } \\
\text { employee of }\end{array}$ & 0 & 0 & 0 & 0 & 0 & 0 & 0 \\
\hline
\end{tabular}




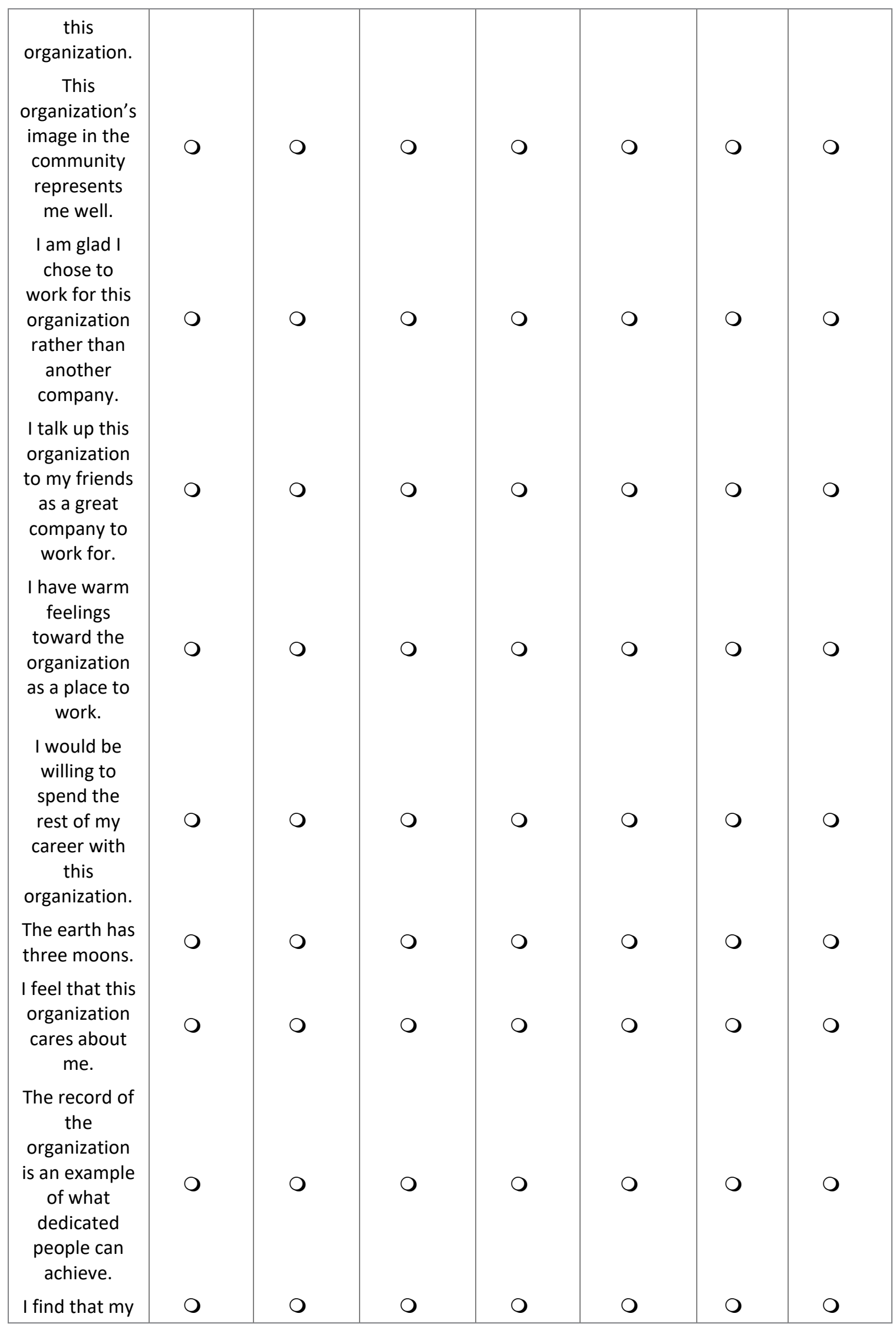




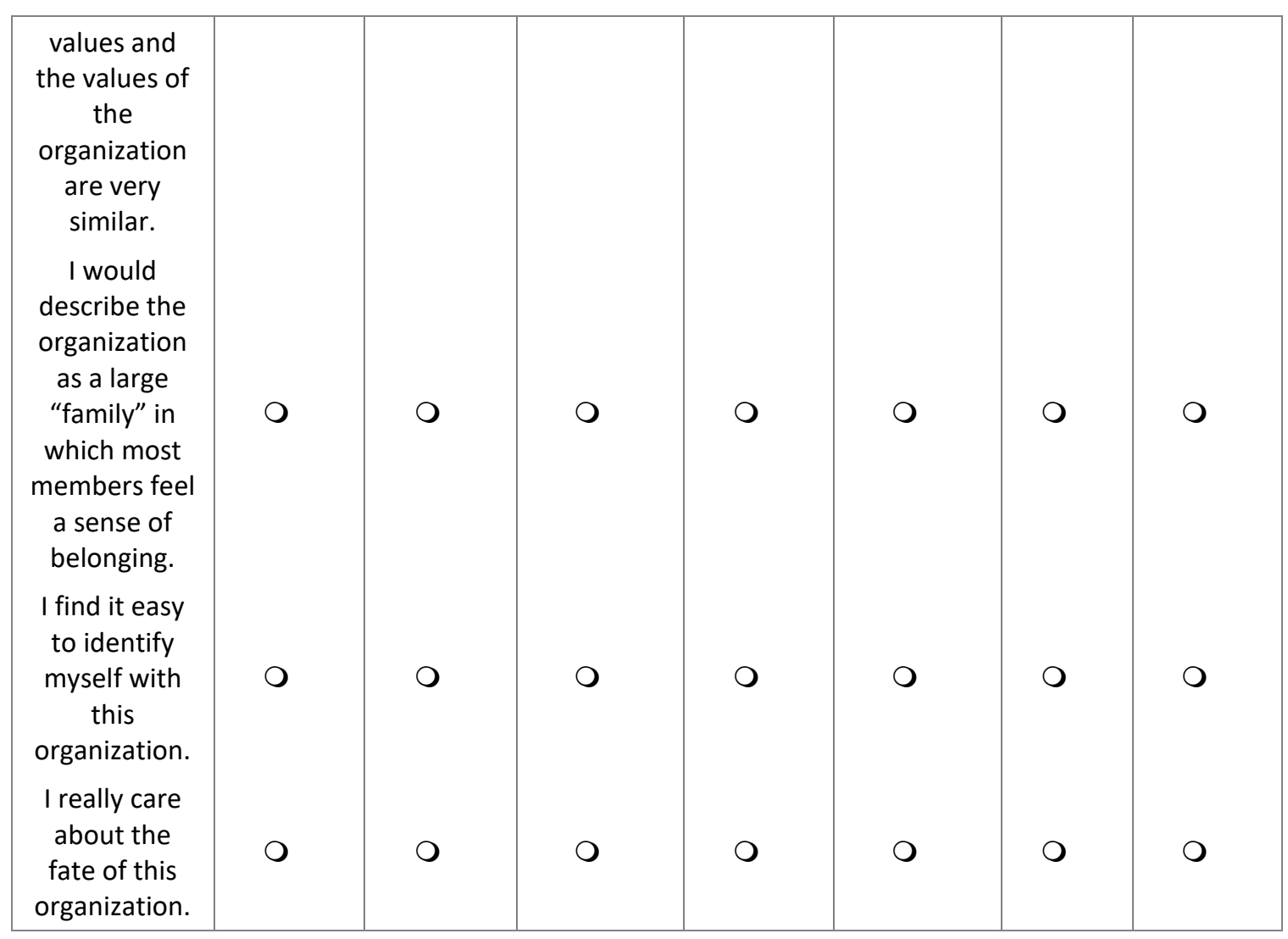

Again, with respect to your own feelings about the organization at which you are currently employed, please indicate the extent of your agreement or disagreement with each of the following statements.

\begin{tabular}{|c|c|c|c|c|c|c|c|}
\hline & $\begin{array}{c}\text { Strongly } \\
\text { disagree }\end{array}$ & Disagree & $\begin{array}{c}\text { Somewhat } \\
\text { disagree }\end{array}$ & $\begin{array}{c}\text { Neither } \\
\text { agree nor } \\
\text { disagree }\end{array}$ & $\begin{array}{c}\text { Somewhat } \\
\text { agree }\end{array}$ & Agree & $\begin{array}{c}\text { Strongly } \\
\text { agree }\end{array}$ \\
\hline $\begin{array}{c}\text { I am willing to } \\
\text { put in a great } \\
\text { deal of effort } \\
\text { beyond that } \\
\text { normally } \\
\text { expected in } \\
\text { order to help } \\
\text { this }\end{array}$ & 0 & 0 & 0 & 0 & 0 & 0 & 0 \\
$\begin{array}{c}\text { organization } \\
\text { be successful. } \\
\text { I talk up this } \\
\text { organization } \\
\text { to my friends } \\
\text { as a great } \\
\text { organization } \\
\text { for which to } \\
\text { work. }\end{array}$ & 0 & 0 & 0 & 0 & 0 & 0 & \\
\hline
\end{tabular}




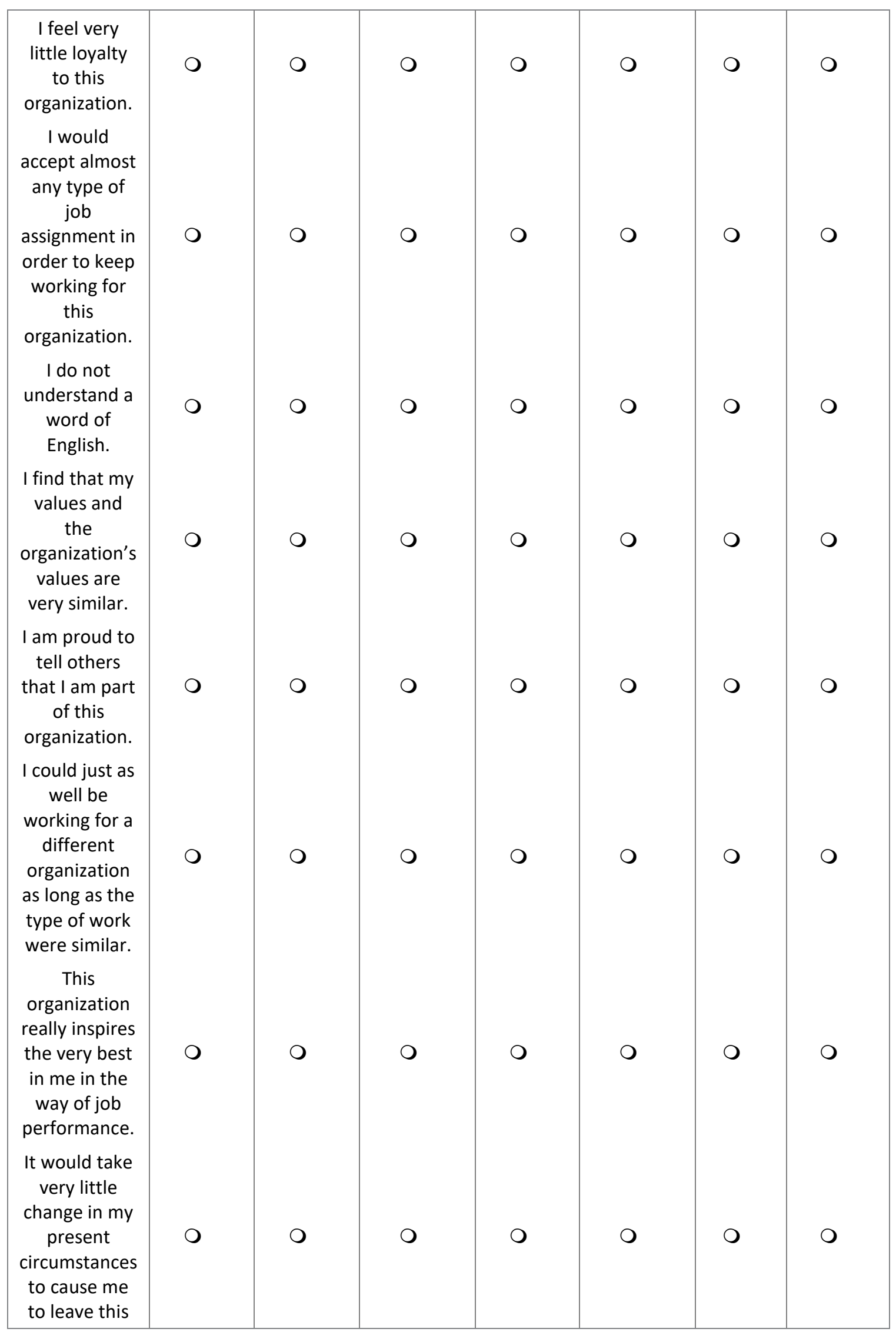




\begin{tabular}{|c|c|c|c|c|c|c|c|}
\hline $\begin{array}{l}\text { organization. } \\
\text { I am } \\
\text { extremely } \\
\text { glad that I } \\
\text { chose this } \\
\text { organization } \\
\text { to work for } \\
\text { over others I } \\
\text { was } \\
\text { considering at } \\
\text { the time I } \\
\text { joined. }\end{array}$ & 0 & 0 & 0 & 0 & 0 & 0 & 0 \\
\hline $\begin{array}{l}\text { There's not } \\
\text { too much to } \\
\text { be gained by } \\
\text { sticking with } \\
\text { this } \\
\text { organization } \\
\text { indefinitely. }\end{array}$ & 0 & 0 & O & 0 & 0 & 0 & 0 \\
\hline $\begin{array}{l}\text { Often, I find it } \\
\text { difficult to } \\
\text { agree with } \\
\text { this } \\
\text { organization's } \\
\text { policies on } \\
\text { important } \\
\text { matters } \\
\text { relating to its } \\
\text { employees. }\end{array}$ & 0 & 0 & 0 & 0 & 0 & 0 & 0 \\
\hline $\begin{array}{l}\text { I really care } \\
\text { about the } \\
\text { fate of this } \\
\text { organization. }\end{array}$ & 0 & 0 & 0 & 0 & 0 & 0 & $\bigcirc$ \\
\hline $\begin{array}{c}\text { For me this is } \\
\text { the best of all } \\
\text { possible } \\
\text { organizations } \\
\text { for which to } \\
\text { work. }\end{array}$ & 0 & 0 & 0 & 0 & 0 & 0 & 0 \\
\hline $\begin{array}{l}\text { Deciding to } \\
\text { work for this } \\
\text { organization } \\
\text { was a definite } \\
\text { mistake on } \\
\text { my part. }\end{array}$ & 0 & 0 & 0 & 0 & 0 & 0 & 0 \\
\hline
\end{tabular}


The following are possible descriptions of perceptions that individuals might have toward their job. Please consider your general feelings toward your current job, and indicate the extent of your agreement or disagreement with each of the following statements.

My current job...

\begin{tabular}{|c|c|c|c|c|c|c|c|}
\hline & $\begin{array}{l}\text { Strongly } \\
\text { disagree }\end{array}$ & Disagree & $\begin{array}{l}\text { Somewhat } \\
\text { disagree }\end{array}$ & $\begin{array}{l}\text { Neither } \\
\text { agree nor } \\
\text { disagree }\end{array}$ & $\begin{array}{l}\text { Somewhat } \\
\text { agree }\end{array}$ & Agree & $\begin{array}{l}\text { Strongly } \\
\text { agree }\end{array}$ \\
\hline is good. & $\mathrm{O}$ & 0 & $\mathrm{O}$ & O & O & 0 & $\mathrm{O}$ \\
\hline $\begin{array}{c}\text { is } \\
\text { undesirable. }\end{array}$ & 0 & $O$ & 0 & 0 & $\mathrm{O}$ & 0 & 0 \\
\hline $\begin{array}{l}\text { is better } \\
\text { than most. }\end{array}$ & $\mathrm{O}$ & 0 & $\mathrm{O}$ & $\mathrm{O}$ & O & 0 & $\mathrm{O}$ \\
\hline $\begin{array}{c}\text { is } \\
\text { disagreeable. }\end{array}$ & 0 & 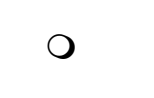 & O & 0 & O & 0 & $\mathrm{O}$ \\
\hline $\begin{array}{l}\text { makes me } \\
\text { content. }\end{array}$ & $\mathrm{O}$ & $\mathrm{O}$ & O & O & O & 0 & $\mathrm{O}$ \\
\hline is excellent. & $\mathrm{O}$ & 0 & $\mathrm{O}$ & O & O & O & $\mathrm{O}$ \\
\hline is enjoyable. & 0 & 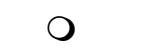 & O & 0 & 0 & 0 & $\mathrm{O}$ \\
\hline is poor. & 0 & 0 & 0 & 0 & 0 & 0 & $\mathrm{O}$ \\
\hline
\end{tabular}

Now, please provide the following information about yourself and the direct supervisor on whom you reported at the beginning of this survey. Your direct supervisor is someone to whom you report who has the formal authority to direct and evaluate your performance within your organization.

What is your sex?

O Male

O Female

What is your direct supervisor's sex?

O Male

O Female

What is your age?

To the best of your knowledge, what is your direct supervisor's age? 
What is your ethnicity?

Asian/Asian American

O Black/African American

O Hispanic

O Middle Eastern

O Native American

O White/Caucasian

Other (specify):

What is your supervisor's ethnicity?

O Asian/Asian American

O Black/African American

Hispanic

O Middle Eastern

O Native American

O White/Caucasian

Other (specify):

How many years of overall work experience do you have?

How long have you been employed at your current organization? (in years)

Do you telecommute to this organization?

O Yes

O No

In which country is this organization located?

Afghanistan

O Albania

Algeria

O Andorra

O Angola

O Antigua and Barbuda

Argentina

O Armenia 


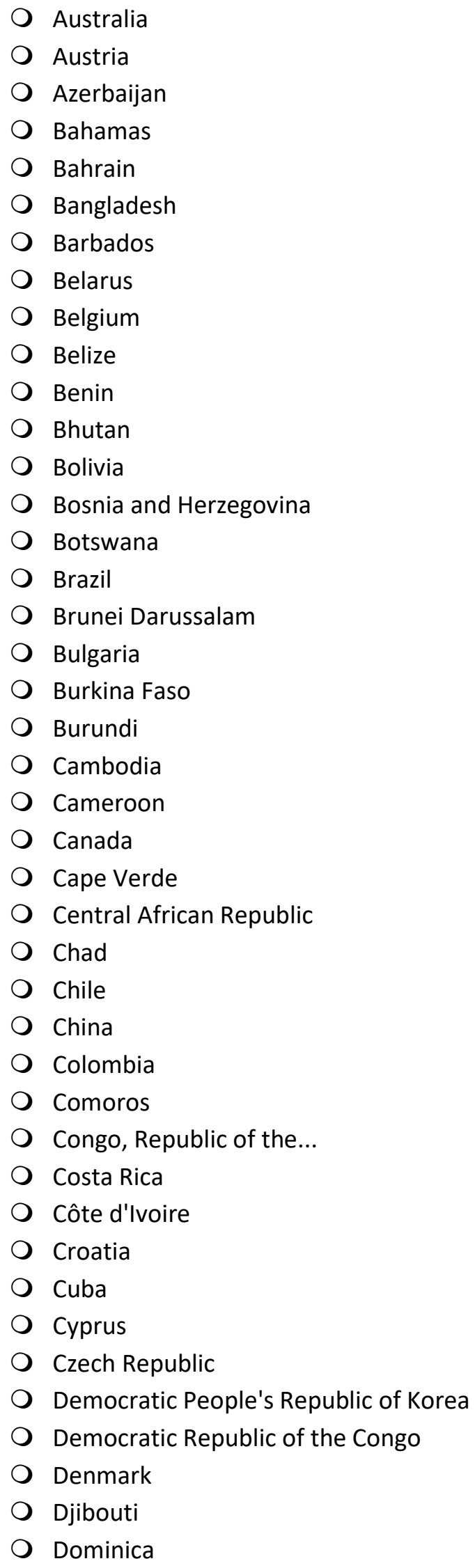




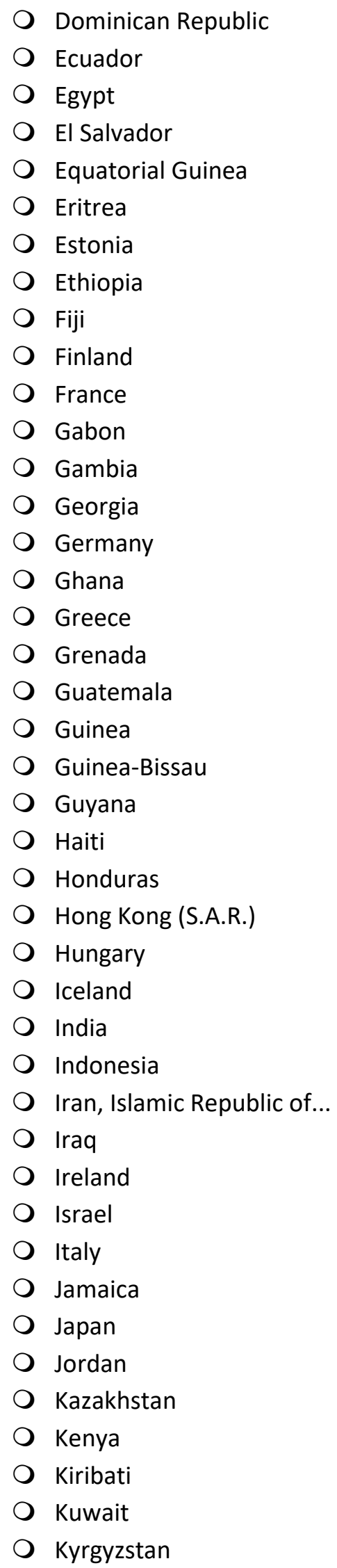




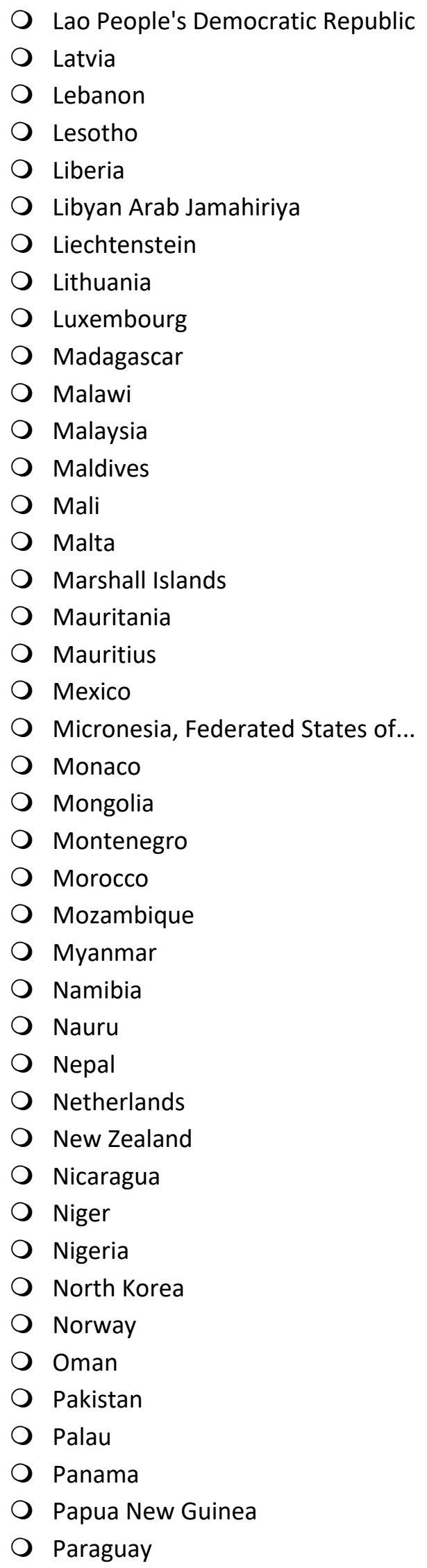




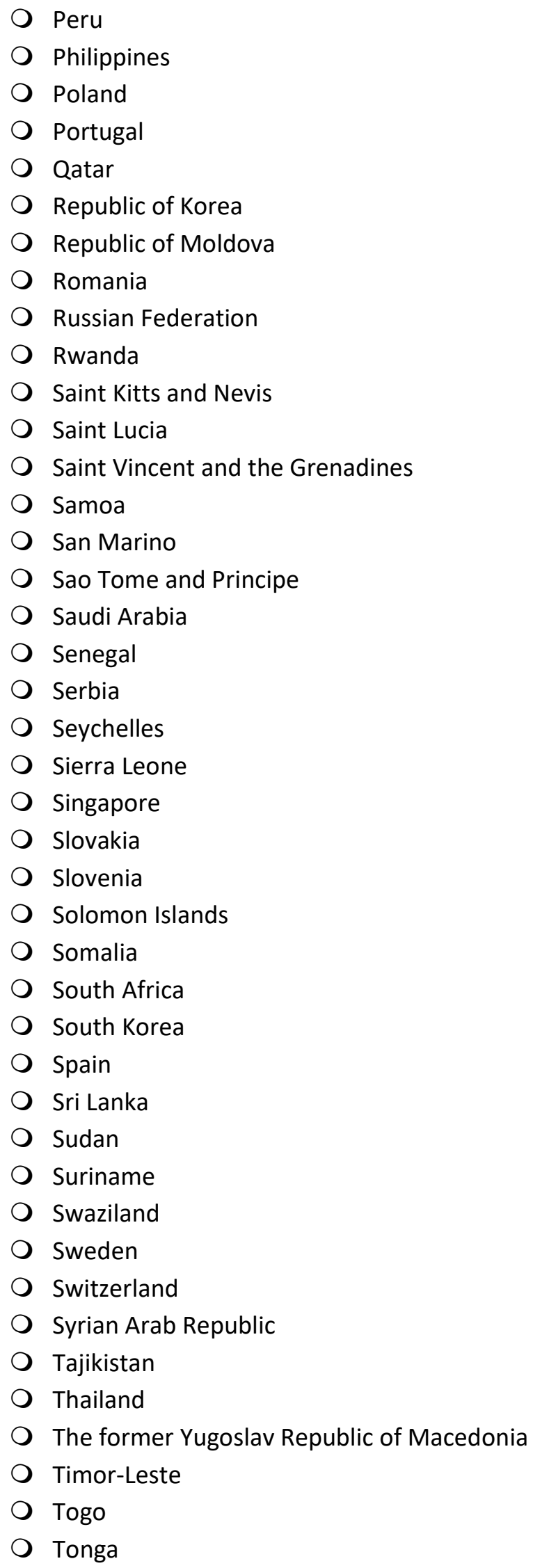




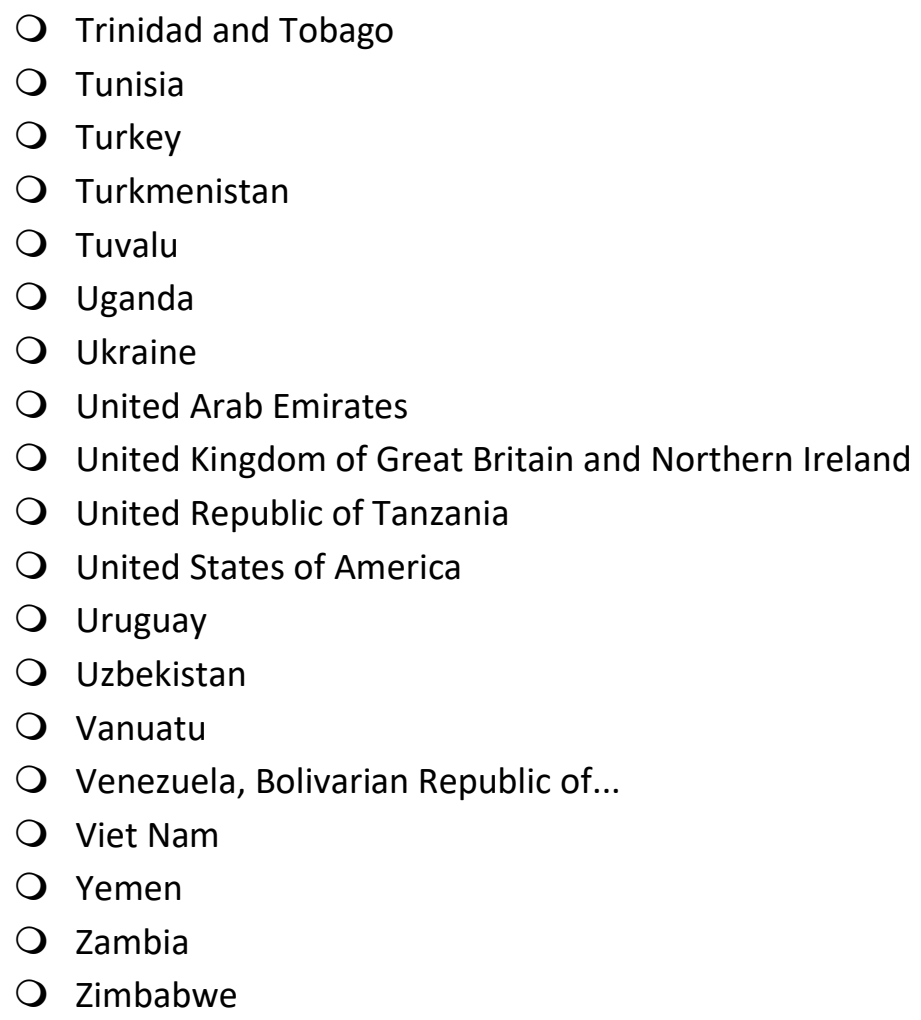

How long have you been employed in your current job position? (in years)

What is your job title?

In your current work position, how long have you and your supervisor worked together? (in years)

Which term best describes your position?

Top management

O Management

O Nonmanagement

Other (please specify)

Are you currently enrolled as a college student?

O Yes

O No 
Which best describes your organization?

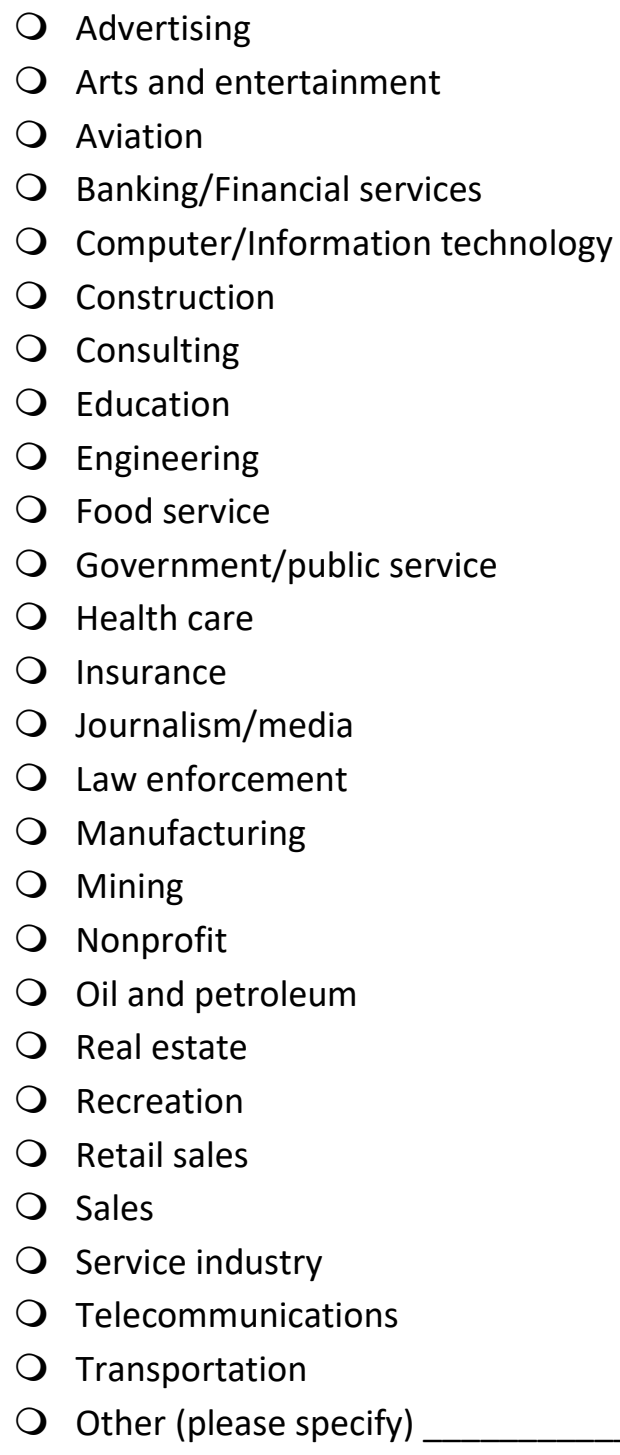

Thank you for your participation! 


\section{Appendix D}

Shortened Organizational Identification Questionnaire (Miller et al., 2000)

If you strongly agree with the statement, put a 7 in the blank.

If you agree with the statement, put a $\mathbf{6}$ in the blank.

If you agree somewhat with the statement, put a $\mathbf{5}$ in the blank.

If you neither agree nor disagree with the statement, put a 4 in the blank.

If you disagree somewhat with the statement, put a $\mathbf{3}$ in the blank.

If you disagree with the statement, put a $\mathbf{2}$ in the blank.

If you strongly disagree with the statement, put a $\mathbf{1}$ in the blank.

1. I am proud to be an employee of this organization.

2. This organization's image in the community represents me well.

3. I am glad I chose to work for this organization rather than another company.

4. I talk up this organization to my friends as a great company to work for.

5. I have warm feelings toward the organization as a place to work.

6. I would be willing to spend the rest of my career with this organization.

7. The earth has three moons.*

8. I feel that this organization cares about me.

9. The record of the organization is an example of what dedicated people can achieve.

10. I find that my values and the values of the organization are very similar.

11. I would describe the organization as a large "family" in which most members feel a sense of belonging.

12. I find it easy to identify myself with this organization.

13. I really care about the fate of this organization.

Note. Item marked with $*$ indicates filler item included to ensure data quality standards. 
Appendix E

Mentor Role Instrument (Ragins \& McFarlin, 1990)

If you strongly agree with the statement, put a 7 in the blank.

If you agree with the statement, put a $\mathbf{6}$ in the blank.

If you agree somewhat with the statement, put a $\mathbf{5}$ in the blank.

If you neither agree nor disagree with the statement, put a $\mathbf{4}$ in the blank.

If you disagree somewhat with the statement, put a $\mathbf{3}$ in the blank.

If you disagree with the statement, put a $\mathbf{2}$ in the blank.

If you strongly disagree with the statement, put a $\mathbf{1}$ in the blank.

My supervisor...

1. helps me attain desirable positions.

2. uses his/her influence in the organization for my benefit.

3. uses his/her influence to support my advancement in the organization.

4. suggests specific strategies for achieving career aspirations.

5. gives me advice on how to attain recognition in the organization.

6. helps me learn about other parts of the organization.

7. "runs interference" for me in the organization.

8. shields me from damaging contact with important people in the organization.

9. protects me from those who are out to get me.

10. provides me with challenging assignments.

11. assigns me tasks that push me into developing new skills.

12. gives me tasks that require me to learn new skills.

13. helps me be more visible in the organization.

14. creates opportunities for me to impress important people in the organization.

15. brings my accomplishments to the attention of important people in the organization.

16. is someone I can confide in.

17. provides support and encouragement.

18. is someone I can trust.

19. serves as a role model for me.

20. represents who I want to be.

21 . is someone I identify with.

22. guides my personal development.

23. serves as a sounding board for me to develop and understand myself.

24. guides my professional development.

25. accepts me as a competent professional.

26. thinks highly of me.

27. sees me as being competent.

28. please select Strongly Agree.*

Note. Item marked with * indicates filler item included to ensure data quality standards. Items 1-3 
measure sponsorship, items 4-6 measure coaching, items 7-9 measure protection, items 10-12 measure challenging assignments, items 13-15 measure exposure and visibility, items 16-18 measure friendship, items 19-21 measure role modeling, items 22-24 measure counseling, and items 25-27 measure acceptance and confirmation. 


\section{Appendix F}

Abridged Job in General Scale (Russell, et al., 2004)

If you strongly agree with the statement, put a 7 in the blank.

If you agree with the statement, put a $\mathbf{6}$ in the blank.

If you agree somewhat with the statement, put a $\mathbf{5}$ in the blank.

If you neither agree nor disagree with the statement, put a 4 in the blank.

If you disagree somewhat with the statement, put a $\mathbf{3}$ in the blank.

If you disagree with the statement, put a $\mathbf{2}$ in the blank.

If you strongly disagree with the statement, put a $\mathbf{1}$ in the blank.

My current job...

1. is good.

2. is undesirable.

3 . is better than most.

4. is disagreeable.

5. makes me content.

6 . is excellent.

7. is enjoyable.

8. is poor.

Note. Bolded items are reverse-coded. 
Appendix G

Interpersonal Communication Satisfaction Inventory (Hecht, 1978)

If you strongly agree with the statement, put a 7 in the blank.

If you agree with the statement, put a $\mathbf{6}$ in the blank.

If you agree somewhat with the statement, put a $\mathbf{5}$ in the blank.

If you neither agree nor disagree with the statement, put a $\mathbf{4}$ in the blank.

If you disagree somewhat with the statement, put a $\mathbf{3}$ in the blank.

If you disagree with the statement, put a $\mathbf{2}$ in the blank.

If you strongly disagree with the statement, put a $\mathbf{1}$ in the blank.

When communicating with my immediate supervisor I feel...

1. he or she lets me know that I am communicating effectively.

2. nothing is ever accomplished.

3. I would like to continue having conversations like ours.

4. he or she genuinely wants to get to know me better.

5. very dissatisfied with our conversations.

6. like I have something else to do.

7. I am able to present myself as I want him or her to view me.

8. he or she shows me that he or she understands what I have to say.

9. a kangaroo is a whale.*

10. very satisfied with our conversations.

11. he or she expresses a lot of interest in what I say.

12. I do not enjoy our conversations.

13. he or she does not provide support for what he or she says.

14. that I can talk about anything with him or her.

15. that we each get to say what we want.

16. that we can laugh easily together.

17. conversations flow smoothly.

18. he or she changes the topic when his or her feelings are brought into the conversation.

19. he or she frequently says things which add little to the conversation.

20. we often talk about some things I am not interested in.

Note. Item marked with * indicates filler item included to ensure data quality standards. Bolded items are reverse-coded. 
Appendix $\mathrm{H}$

Organizational Commitment Questionnaire (Mowday et al., 1979)

If you strongly agree with the statement, put a 7 in the blank.

If you agree with the statement, put a $\mathbf{6}$ in the blank.

If you agree somewhat with the statement, put a $\mathbf{5}$ in the blank.

If you neither agree nor disagree with the statement, put a $\mathbf{4}$ in the blank.

If you disagree somewhat with the statement, put a 3 in the blank.

If you disagree with the statement, put a $\mathbf{2}$ in the blank.

If you strongly disagree with the statement, put a $\mathbf{1}$ in the blank.

1. I am willing to put in a great deal of effort beyond that normally expected in

order to help this organization be successful.

2. I talk up this organization to my friends as a great organization to work for.

3. I feel very little loyalty to this organization.

4. I would accept almost any type of job assignment in order to keep working for this organization.

5. I do not understand a word of English.*

6. I find that my values and the organization's values are very similar.

7. I am proud to tell others that I am part of this organization.

8. I could just as well be working for a different organization as long as the type of work were similar.

9. This organization really inspires the very best in me in the way of job performance.

10. It would take very little change in my present circumstances to cause me to leave this organization.

11. I am extremely glad that I chose this organization to work for, over others I was considering at the time I joined.

\section{indefinitely. \\ 12. There's not too much to be gained by sticking with this organization} 13. Often, I find it difficult to agree with this organization's policies on important matters relating to its employees.

14. I really care about the fate of this organization.

15. For me this is the best of all possible organizations for which to work.

16. Deciding to work for this organization was a definite mistake on my part.

Note. Item marked with * indicates filler item included to ensure data quality standards. Bolded items are reverse-coded. 